University of Rhode Island

DigitalCommons@URI

Open Access Dissertations

1980

\title{
The Growth and Life-History Strategy of the Soft-Shell Clam, Mya
} arenaria $L$.

Richard S. Appeldoorn

University of Rhode Island

Follow this and additional works at: https://digitalcommons.uri.edu/oa_diss

\section{Recommended Citation}

Appeldoorn, Richard S., "The Growth and Life-History Strategy of the Soft-Shell Clam, Mya arenaria L." (1980). Open Access Dissertations. Paper 782.

https://digitalcommons.uri.edu/oa_diss/782

This Dissertation is brought to you for free and open access by DigitalCommons@URI. It has been accepted for inclusion in Open Access Dissertations by an authorized administrator of DigitalCommons@URI. For more information, please contact digitalcommons-group@uri.edu. 


\section{THE GROWTH AND LIFE-HISTORY STRATEGY OF THE SOF T-SHE LL CLAM, Mya arenaria L. BY}

R IC HARD S. APPE LDOORN

A DISSERTATION SUBMITTED IN PARTIAL FULF ILLMENT OF THE REQUIREMENTS FOR THE DEGREE OF DOCTOR OF PHILOSOPHY IN OC EA NOGRA PHY 


\section{ABSTRACT}

The growth and life-history strategy of the soft-shell clam, Mya arenaria were analyzed through the examination of 25 populations spread throughout the species' geographic range. Growth rate was determined by length-frequency analysis and was analyzed using Gallueci and Quinn's $w$ parameter of the von Bertalanffy equation. Principal components analysis (PCA) was used to analyze environmental variability. Variations in growth were related to environmental differences. Growth varied inversely with latitude. This relationship was due mostly to temperature differences. PCA indicated that several environmental factors varied systematically with latitude. Growth was found to be negatively correlated to the siltiness of the sediment and to the concentration of sedimentary hydrocarbons. Distinct shifts in growth rate occurred when environmental quality was significantly altered by a discrete pollution event. Growth was reduced in response to heavy metal effluents and oil spills. Fairly rapid recovery followed heavy metal pollution abatement. Recovery at oil spill sites was variable but slow.

The relationships between various life-history parameters were analyzed to elucidate the species' modes of adaptation and life-history strategy. Within the context of latitudinal variations in the environment an association was found between decreasing latitude and: faster growth, greater variation in juvenile mortality, larger maturation size, larger egg size, lower egg density and decreasing longevity. These relationships indicated that M. arenaria follows a bet-hedging life-history strategy. On a local scale a 
positive relationship was found between larger egg size and greater egg density. This trend appeared to be associated with the condition of the population and may represent a physiological response to local environmental conditions.

The proportion of females (52\%) was found to be significantly greater than the proportion of males. No evidence of a mechanism behind this disparity was detected. 


\section{PREFACE}

This thesis was prepared according to manuscript format. Three manuscripts are presented and each is written in a style appropriate for submition to a particular scientific journal. The first manuscript will be submitted to Marine Biology; the second manuscript has been submitted to the Proceedings of the National Shellfisheries Association; and the third manuscript will be submitted to Oecologia.

The thesis as a whole constitutes an analysis of data collected during a stuo y of neoplasia in Mya arenaria and pollution in the environment. Two limitations were encountered. First, because the analysis was designed after data collection many of the measurements in the raw data were not entirely suited for their application in this study. The problems included no or insufficient data and too much variability in the measurements. These problems could have been solved at the time of sampling. Second, no attempt was made to investigate and support conclusions based on the data analysis throug further sampling or experimentation. Al though such work would be a welcome addition, it is believed that this work would constitiute a thesis unto itself. It is felt that the present analysis can stand by itself with the questions remaining to be answered serving as an incentive for further study. 


\section{AC KNOWLE DGEM ENTS}

Many people, at various levels and degrees, were involved in this study. Special thanks go to Saul Saila, my major professor, who provided financial support for data collection and analysis (through a grant from the American Petroleum Institute), and who provided helpful ideas, moral support, and valuable criticism throughout $\mathrm{my}$ graduate tenure. Equal thanks go to my parents and to M. Schwanke for their loving moral support and critical financial support during leaner times. Drs. R.C. Bullock and A. N. Sastry gave helpful suggestions for the thesis and provided valued commentary on graduate education in general. Many people were involved in data collection. I would particularly like to acknowledge the assistance of R.L. Dow, M. Richards, J.M. Hickey, M.L.H. Thomas, and M. Worobec in clam collection. R.S. Brown, J. Keller, A. Miller, S. Polofsky, and others at Peckham Farm were responsible for much of the sample processing and data compilation. Several people, particularly H. Walker, helped soothe my statistical nightmares, real or imagined. C. Brown and E. Frankl in provided the hydrocarbon analyses used in this study. Technical assistance in analysis and manuscript preparation was provided by Drs. R.L. MacMaster, T.A. Napora, and R. E. Wolke. I am grateful to $m y$ friends for having put up with me and my sense of humor (real or imagined?) and for providing valued companionship. 
Abstract

Acknowledgements

iii

Preface

iv

Table of contents

\section{$\mathrm{v}$}

List of Tables vii

List of Figures ix

Variations in the growth rate of Mya arenaria and its relationship to the environment as analyzed through principal components analysis and the $w$ paramter of the von Bertalanffy equation

$\begin{array}{lr}\text { Title page } & 1 \\ \text { Abstract } & 2 \\ \text { Introduction } & 3 \\ \text { Materials and methods } & 4 \\ \text { Results } & 14 \\ \text { Discussion } & 25 \\ \text { Acknowledgements } & 36 \\ \text { Literature cited } & 37\end{array}$

The response of population growth rate in the soft-shell clam, Mya arenaria, to the onset and abatement of pollution

Title page

Abstract.

Introduction

Methods

Results

Discussion 
$\begin{array}{ll}\text { Acknowl edgements } & 69\end{array}$

$\begin{array}{ll}\text { Literature cited } & 70\end{array}$

Adaptations to environmental variation and the life-ristory strategy of the soft-shell clam, Mya arenaria: relationships between parameters.

$\begin{array}{ll}\text { Title page } & 75\end{array}$

$\begin{array}{ll}\text { Summary y } & 76\end{array}$

$\begin{array}{ll}\text { Introduction } & 77\end{array}$

$\begin{array}{ll}\text { Materials and methods } & 79\end{array}$

$\begin{array}{lr}\text { Results } & 85\end{array}$

$\begin{array}{ll}\text { Discussion } & 87\end{array}$

Ac knowledgements $\quad 95$

$\begin{array}{ll}\text { References } & 96\end{array}$

$\begin{array}{ll}\text { Appendix A. Complete references cited } & 102\end{array}$ 
Adaptations to environmental variation and the life-ristory strategy of the soft-shell clam, Mya arenaria:

relationships between parameters.

1. Life-history parameters estimated for each population

2. Results of the functional regressions

3. Pair-wise comparisons of egg density, egg diameter, and DSI 
Variations in the growth rate of Mya arenaria and its relationship to the environment as analyzed through principal components analysis and the $w$ parameter of the von Bertalanffy equation

1. Mya arenaria. Location of sampling sites

2. Mya arenaria. An example of a length-

frequency histogram showing superimposed

distributions for each age group as

determined with the curve resolver

3. Mya arenaria. A plot of growth rate

versus latitude

4. Mya arenaria. A plot of the common logarithm of the growth rate $(\omega)$ versus the first principal component - northness

5. Mya arenaria. A plot of the residual of growth rate versus the second principal component - sil tiness

6. Mya arenaria. A plot of the second residual of growth rate versus the third principal component - sedimentary hydrocarbons.

The response of population growth rate in the soft-shell clam, Mya arenaria, to the onset and abatement of pollution

1. Length-frequency histogram for Janvrin Lagoon with superimposed distributions for each age group as determined with the curve resolver

2. Age-leng th curve for Janvrin Lagoon, N.S.

3. Age-leng th curve for Sear sport, Maine

4. Age-length curve for West Falmouth, Mass.

5. Age-length curve for Bourne, Mass.

6. Age-length curve for Perry, Maine

7. Age-length curve for Goose Cove, Maine 
Adaptations to environmental variation and the life-history strategy of the soft-shell clam, Mya arenaria: relationships between parameters.

1. Location of sampling sites 
VARIATION IN THE GROWTH RATE OF Mya arenaria AND ITS RELATIONSHIP TO THE ENVIRONMENT AS ANALYZED THROUGH PR INC IPA L COMPONENTS ANALYSIS AND THE $\omega$ PARAMETER OF THE VON BERTALANFFY EQUATION

Richard S. Appeldoorn Graduate School of Oceanography Univeristy of Rhode Is 1 and Kingston, Rhode Is 1 and 02881 
ABSTRACT

The growth rate of the soft-shell clam. Mya arenaria, was estimated for 25 populations using length-frequency analysis. Variations in the growth rate between populations were related to differences in the environment. The analysis of growth was based on Gallucci and Quinn's w parameter for the von Bertalanffy equation. Environmental variability was analyzed using principal component analysis. This analysis yielded three environmental factors: northness, siltiness, and sedimentary hydrocarbons. Growth was found to be significantly related to each of the three components. A distinct latitudinal growth relationship was observed with growth decreasing towards the north. Analysis of the first component, northness, showed that many environmental factors (temperature, tidal height, tidal position, edaphic conditions) systematically varied with latitude. The analysis indicated that temperature was the dominant factor responsible for the latitudinal trend in growth. Growth was negatively related to both siltiness and sedimentary hydrocarbons. Both principal component analysis and the parameter w proved to be useful for the detailed study of environmental variability and growth variations respectively. 


\section{INTRODUCTION}

The growth of Mya arenaria, the soft-shell clam, has been studied by many investigators (Wilton and Wilton, 1929; Belding, 1930; Newcombe, 1936; Swan, 1952; Brouseau, 1979; and others) and much work has been done in assessing the importance of various environmental factors to the growth process. These factors include water current and quality, food, temperature, sal inity, various edaphic parameters, and pollution. In the past, investigators were obliged to study these factors individually even though it was realized that many were interrelated (Belding, 1930). Researchers often disagreed on the relative importance of each of these factors. With the advent of high-speed computers and the development of more sophisticated analytical tecrniques it is now possible to efficiently anal yze complex ecological systems involving multiple factors.

The purpose of this study was to investigate the factors contributing to variations in the growth rate of soft clam populations. Principal components analysis was chosen for the multivariate analysis of the environmental data and the von Bertalanffy model was chosen for the analysis of growth using the recently introduced growth parameter $\omega$ of Gallucci and Quinn (1979). This study represents one of the first applications of $w$ for the investigation of growth $\mathrm{variations.} \mathrm{Of} \mathrm{specific} \mathrm{interest} \mathrm{was} \mathrm{a}$ methodology which could establish the presence or absence of a latitudinal trend in growth and the factors responsible for it, since a definite relationship had yet to be demonstrated (Brouseau, 1979). 
MATERIALS AND METHODS

The growth of Mya arenaria was studied at 25 sites located along the east coast of North America from Maryl and to Nova Scotia (Figure 1). The sites were initially chosen and sampled as part of a study investigating the relationship between environmental pollution and neoplasia in Mya arenaria (Brown et al., 1979) and as such they varied greatly in their environmental qualtiy. Estimates of the following environmental parameters were obtained for each site: salinity, tidal position, tidal range, average annual temperature, sedimentary grain size, dispersion and skewness of grain sizes, percent silt-clay, percent organic matter, and total sedimentary hydrocarbons.

Sal inity, at low tide, was measured using a refractometer; tidal position was estimated on a scale of $0-1$ where 0 * subtidal (never exposed) and 1 full exposure (never submerged). Estimates of the average annual temperature at each site were obtained from various 1 iterature sources; estimates of the tidal range were obtained from the National Ocean Survey (1978).

Sediment samples were collected and analyzed to determine the amount of organic matter and the grain size distribution. Each sample consisted of a composite of two surface cores $\left(21 \mathrm{~cm}^{2} \times 8\right.$ an depth) which were kept frozen prior to analysis. Using a $74 \mu \mathrm{m}$ mesh screen an aliquot of the sediment sample was wet sieved to separate the sand fraction from the silt-clay fraction (Buchanann, 1971). The sand fraction was further analyzed by dry sieving (ASTM, 1962 ) using 7 screens (ranging from $4-0.062 \mathrm{~mm}$ mesh) set at one phi $(\phi)$ intervals. The phi scale is a log function of the millimeter 
Figure 1. Mya arenaria. Location of sampling sites. 


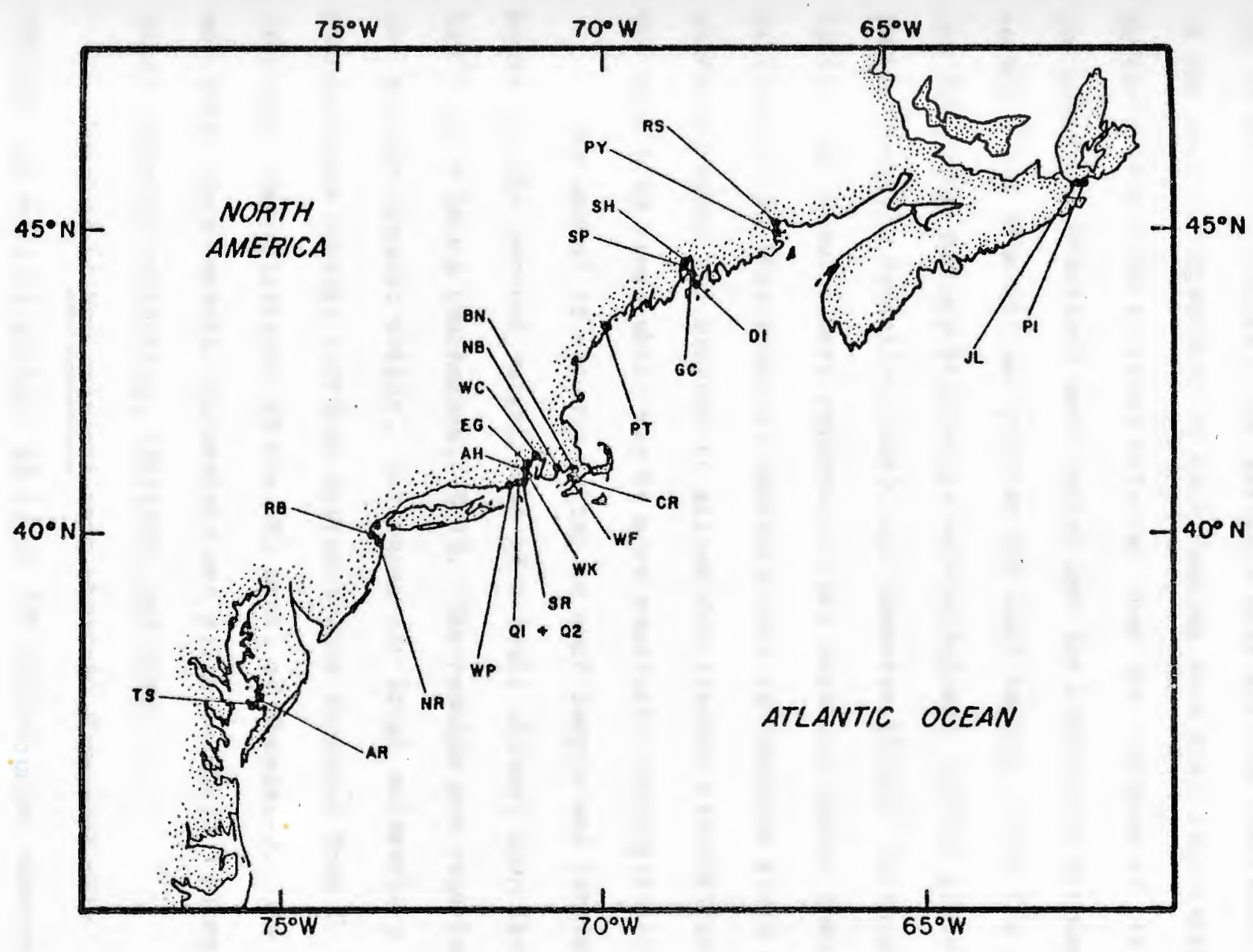


scale where $\phi=-\log _{2}(\mathrm{~mm})$. The silt-clay fraction was analyzed using the hydrometer method (ASTM, 1962) with reading s taken at 2, 15, 60 and 120 minutes. The particle size and the cumulative percent of the sample represented at each reading were then calculated. The particle size distributions obtained from the analyses of the sand and silt-clay fractions were pooled and the cumulative frequency versus grain size ( $\phi)$ was plotted for each sample. From the graphs the following summary statistics were obtained: median grain size

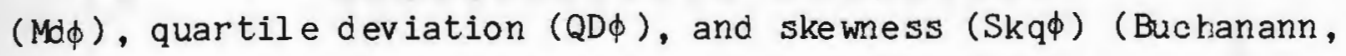
1971). The results were reported in phi notation rather than in millimeters as this scale is commonly used to describe grain size characteristics and because it allows for greater discrimination in the silt-clay range which may be more meaningful biologically.

The amount of organic matter in each sample was determined by measuring the percent weight loss of a small aliquot upon ignition at $550^{\circ} \mathrm{C}$ for 4 hours (Buchanann, 1971). The results are reported as the percent organic matter. Estimates for total sedimentary hydrocarbons through infrared analysis were obtained from C. Brown (personal communication) of the URI Dept. of Chemistry. The sites and their environmental parameters are given in Table 1 along with their dates of collection, latitude, and code.

Samples of Mya arenaria were obtained from each site. An attempt was made to collect at least 180 individuals, however, this was not accomplished on all occassions. For each individual, shell lengtr (maximum shell dimension) was measured to the nearest millimeter using vernier calipers. This information was used to determine the age structure of each population via length-frequency 
Table 1. Sampling sites and their environmental parameters. - : mlss lang value

\begin{tabular}{|c|c|c|c|c|c|c|c|c|c|c|c|c|c|}
\hline $\begin{array}{l}\text { Samp1ing } \\
\text { Site }\end{array}$ & $\begin{array}{l}\text { Site } \\
\text { Code }\end{array}$ & $\begin{array}{l}\text { Date of } \\
\text { Samp1ing }\end{array}$ & $\begin{array}{l}\text { Latitude } \\
\left({ }^{\circ} \mathrm{N}\right)\end{array}$ & $\begin{array}{l}\text { Ave. } \\
\text { Annual } \\
\text { Temp. }\end{array}$ & $\begin{array}{l}\text { TIdal } \\
\text { Range } \\
\text { ft }(m)\end{array}$ & $\begin{array}{l}\text { Tidal } \\
\text { Pusition }\end{array}$ & $\operatorname{Md\phi }$ & QD $\phi$ & $\mathbf{S k q} \phi$ & $\begin{array}{l}\% \\
\text { Silt- } \\
\text { C1ay }\end{array}$ & $\begin{array}{c}\% \\
\text { Organ. } \\
\text { Matter }\end{array}$ & $\begin{array}{l}\text { Total } \\
\text { Sedi. } \\
\text { Hydro. } \\
(\mu g / g)\end{array}$ & $\begin{array}{l}\text { Salln. } \\
\text { (ppt) }\end{array}$ \\
\hline Tangter Scund MD & TS & $27-3-78$ & 37.952 & $15.0_{\mathrm{a}}^{\mathrm{a}}$ & $2.5(0.77)$ & 0 & - & - & - & - & - & - & 11 \\
\hline Big Annemessex Kiver MD & AR & $27-3-78$ & 38.051 & $15.0^{\mathrm{a}}$ & $2.5(0.77)$ & 0 & - & - & - & - & - & - & 11 \\
\hline Navesink River NJ & NR & $2-6-77$ & 40.377 & $13.0_{\mathrm{b}}^{\mathrm{b}}$ & $3.5(1.08)$ & .50 & 1.80 & 0.40 & -0.10 & 1.0 & 1.5 & 114 & 24 \\
\hline Raritan Bay NJ & RB & $1-6-77$ & 40.459 & $13.0^{\circ}$ & $6.0(1.85)$ & .50 & 2.55 & 0.44 & -0.05 & 4.2 & 2.6 & 104 & 24 \\
\hline Winnapaug Pond RI & WP & $18-7-77$ & 41.327 & $12.3^{\mathrm{c}}$ & $2.0(0.62)$ & .50 & 1.97 & 0.62 & 0.01 & 1.5 & 0.7 & 21 & 31 \\
\hline Quonochontaug Pond-1 RI & Q1 & $22-6-76$ & 41.333 & $12.3^{c}$ & $2.0(0.62)$ & .35 & 1.00 & 0.60 & 0.00 & 0.7 & 1.5 & 0 & 31 \\
\hline Quonoctiontaug Pond-2 RI & Q2 & $4-4-77$ & 41.333 & $12.3^{\mathrm{c}}$ & $2.0(0.62)$ & .50 & 3.05 & 0.31 & -0.01 & 8.1 & 1.5 & 9 & 31 \\
\hline Saugatucket RIver RI & SR & $14-12-78$ & 41.423 & $12.3^{\mathrm{c}}$ & $3.0(0.92)$ & .35 & 1.40 & 1.48 & -0.40 & 2.0 & 1.1 & 509 & 16 \\
\hline Wickford RI & WK & $15-3-76$ & 41.566 & $10.5^{d}$ & $4.7(1.45)$ & .35 & 2.92 & .0 .23 & -0.02 & 4.6 & 1.4 & $15^{j}$ & 27 \\
\hline Counamessett River MA & $\mathrm{CR}$ & $12-5-77$ & 41.577 & $11.0^{\mathrm{e}}$ & $4.0(1.23)$ & 0 & 1.10 & 0.59 & -0.05 & 2.7 & 1.0 & 101 & 12 \\
\hline A1len Harbor RI & AH & $27-9-77$ & 41.620 & $12.4^{d}$ & $4.5(1.38)$ & .50 & 4.20 & 0.48 & -0.03 & 61.1 & 1.9 & 358 & 28 \\
\hline West Falmouth MA & $W F$ & $3-5-77$ & 41.633 & $10.5^{2}$ & $5.0(1.54)$ & .50 & 0.46 & 0.80 & 0.27 & 2.1 & 0.8 & 190 & 32 \\
\hline New Bedford MA & NB & $1.8-10-78$ & 41.639 & $10.5^{\mathrm{e}}$ & $4.0(1.23)$ & .35 & 1.39 & 0.72 & 0.07 & 3.0 & 1.5 & 567 & 22 \\
\hline East Greenwlch Cove RI & EG & $3-3-76$ & 41.656 & $11.5^{d}$ & $5.0(1.54)$ & .20 & 2.08 & 1.08 & -0.66 & 3.6 & 1.6 & $24^{k}$ & 19 \\
\hline Bourne MA & BN & $22-5-76$ & 41.682 & $10.5^{\mathrm{e}}$ & $3.8(1.17)$ & .50 & 0.89 & 0.55 & 0.01 & 2.4 & 0.7 & 523 & 30 \\
\hline Watchemoket Cove RI & WC & $12-5-76$ & 41.799 & $11.1_{f}^{d}$ & $5.7(1.75)$ & .50 & - & - & - & - & - & - & 25 \\
\hline Portland $M E$ & PT & $21-7-76$ & 43.636 & $9.1^{\mathrm{f}}$ & $10.4(3.20)$ & .50 & 1.56 & 1.14 & 0.11 & 16.2 & 2.5 & 209 & 27 \\
\hline Deer Isle ME & DI & $22-9-76$ & 44.203 & 7.48 & $11.2(3.45)$ & .80 & 1.90 & 1.38 & 0.57 & 9.8 & 1.6 & 24 & 32 \\
\hline Goose Cove $\mathrm{ME}$ & GC & $20-7-76$ & 44.377 & $\cdot 7.1^{h}$ & $11.1(3.42)$ & .80 & -0.51 & 1.37 & 0.09 & 2.8 & 1.4 & 254 & 20 \\
\hline Long Cove, Seuraport ME & SP & $22-9-76$ & 44.463 & $7.1^{h}$ & $11.5(3.51)$ & .65 & 1.52 & 1.67 & 0.90 & 15.9 & 2.9 & 135 & 25 \\
\hline Stockton Harbor ME & SH & $13-9-78$ & 44.464 & $7.1^{\mathrm{h}}$ & $11.5(3.51)$ & .65 & 0.26 & 2.05 & 0.15 & 7.3 & 1.3 & 399 & 25 \\
\hline Perry ME & PY & $15-8-78$ & 44.9 & 6.7 & $21.0(6.46)$ & .65 & 2.22 & 1.5 & -1.38 & 5 . & 2 & 23 & 30 \\
\hline Robinstun $\mathrm{ME}$ & RS & $15-8-78$ & 45.106 & 6.88 & $21.0(6.46)$ & .65 & -0.41 & 1.53 & 0.27 & 9.6 & 2.2 & 44 & 28 \\
\hline Janvrin Lagoon NS & JL & $18-7-78$ & 45.458 & $9.0^{i}$ & $4.0(1.23)$ & .65 & 2.24 & 0.46 & 0.06 & 8.2 & 1.4 & 177 & 29 \\
\hline Potato Island NS & PI & $18-7-78$ & 45.589 & $9.0^{1}$ & $4.0(1.23)$ & .65 & -0.67 & 1.58 & 0.15 & 10.3 & 4.6 & 20 & 29 \\
\hline
\end{tabular}

a Beaven (1960)

$b_{\text {Jeffries (1962) }}$

CMarine Research (1975)

dilcks (196j)

Etlbert (1973)

filfillan et a1. (1976) gow (Personal communication)

'Shorey (1973).

isamato (1972) and Thomas (1978)

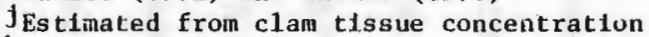

kstimated from gas chromatography measurement 
anal ysis.

A length-frequency histogram for each population was plotted at $1 \mathrm{~mm}$ intervals and the modes on the resulting graph were broken down into a series of normal curves by the Petersen Method (Tesch, 1971; Macdonald and Pitcher, 1979) using a Dupont 310 Curve Resolver. The curve resolver is an analog computer which allows one to break down a complex envelope into its basic components in a graphical fashion. The computer has ten function generator channels each capable of producing a normal curve on a cathode ray tube. The images of these curves can then be projected on to the length-frequency histogram. The histogram can then be broken down left to right in the following manner. The first channel is switched on and the projected curve is positioned such that its location, width, and height correspond to the left edge of the histogram. The remainder of the histogram is then resolved by successively turning on channels and positioning the curves such that the envelope projected (formed by the summation of all the 'on' channels) matches the outline of the histogram. The optical output gives the observer immediate feedback, and repeated trials can be made quickly by varying the size, shape, position, and number of curves until it is felt that a reasonable 'fit' to the data has been obtained. At this point the output of each channel can be turned on and displayed independently, and its projection traced on the histogram. Figure 2 ill ustrates the results of this process. From the resulting graphs the mean and standard deviation of the normal curve representing each mode of the histogram can be obtained. The mean occurs at the peak and the standard deviation is the half-width at $61 \%$ of the height 
Figure 2. Mya arenaria. An example of a length-frequency histogram showing the distributions for each age group as determined with the curve resolver. Solid curves = age groups. Dashed curve = total fitted envelope. The mean plus one standard deviation is shown for the fourth curve. Number above represents the percentage of the sample under each curve respectively. 


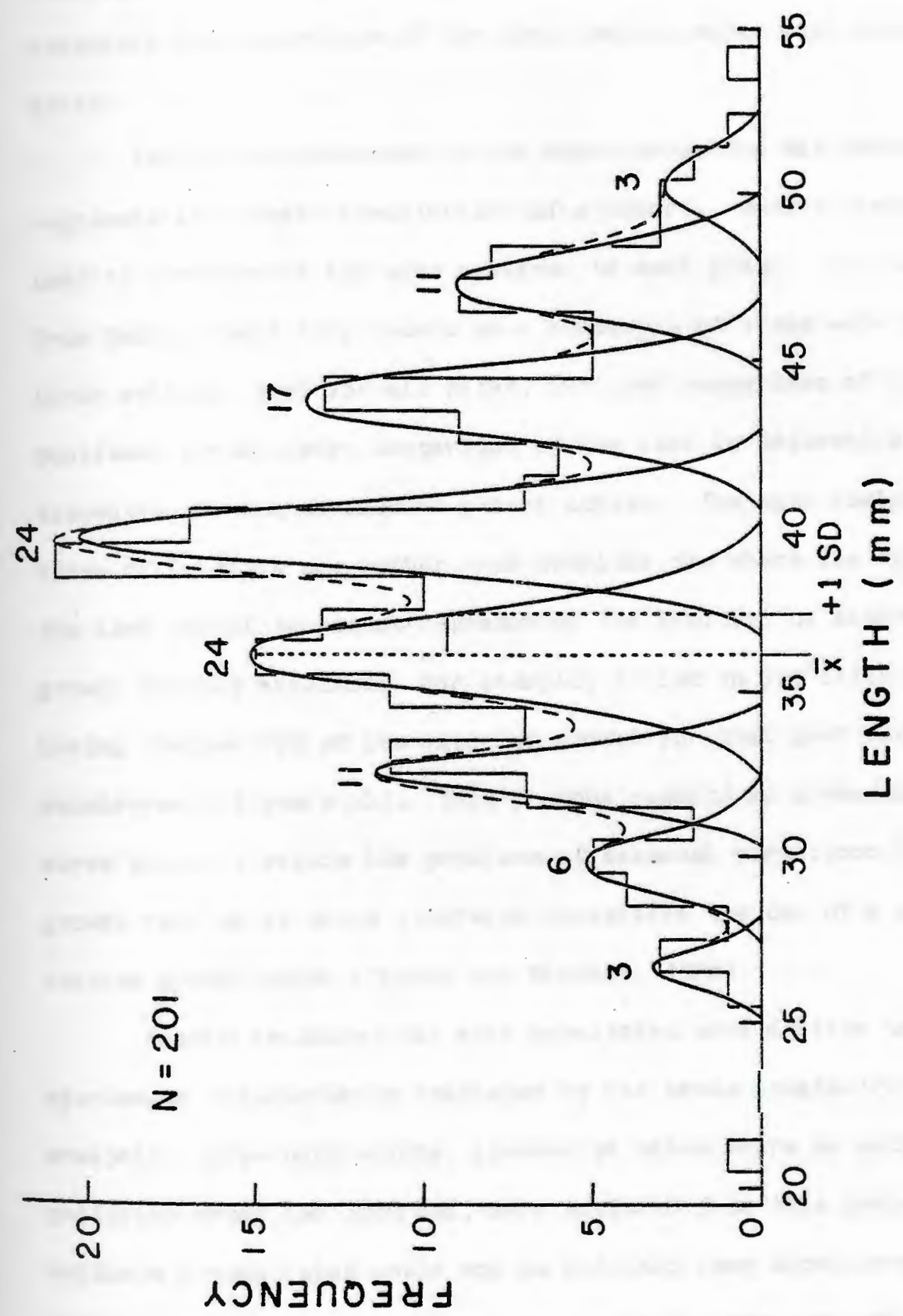


(see curve 4, Figure 2) (Macdonald and Pitcher, 1979). The curve resolver is also equipped with an integrater allowing one to determine the percentage of the whole sample under each component curve.

Each curve generated by the above procedure was assumed to represent the length distribution of a cohort. Several methods were used to corroborate the ages assigned to each group. For samples from Maine, shell ring counts on a subsample of clams were used. Other methods, used for all sites, included comparison of the data to published growth data, comparison of the data to adjacent areas, and inspection of the subsequent growth curves. The ages assigned were those of relative age rather than absolute age where the age beyond the 1 ast annual increment represented the fraction of expected yearly growth already obtained. For example, a clam in its fifth year, having reached 50\% of its expected growth for that year would be considered 4.5 years old. This process results in a smoother growth curve since it avoids the problems of seasonal variations in the growth rate which would otherwise necesitate the use of a more complex growth model ( $\mathrm{Cloern}$ and Nichols, 1978).

Growth estimates for each population were derived using the age-length relationships developed by the above length-frequency analysis. Five populations, located at sites where an acute pollution event had occurred, were excluded from this process because reliable growth rates could not be obtained (see Appeldoorn, 1980). Growtr was estimated by fitting a von Bertal anffy curve to the data. The growth curve is described by the equation: 


$$
L_{-\infty}\left(1-e^{-K\left(t-t_{0}\right)}\right)
$$

where $t=$ time, Lelength at time $t, L_{\infty}$ maximum asymtotic length, $K=$ growth constant, and $t_{0}=$ time when $L=0$. According to the methods of Gallucci and Quinn (1979) the model was fitted to the data by nonl inear least-squares regression using the NLIN procedure of SAS79 (Helwig and Council, 1979). The use of such a nonl inear regression procedure is advantageous since not only are estimates of $K, L_{\infty}$ and $t_{0}$ obtained but estimates of their asymtotic standard errors are also available as well as the correlation coefficient of $\mathrm{K}$ and $L_{\infty},\left(\operatorname{corr}\left(K, L_{\infty}\right)\right)$. Normal linear curve fitting techniques do not allow for estimates of the variance of the parameters and hence the parameters could not be compared statistically.

After obtaining estimates of the von Bertal anffy parameters the growth function was reparameterized to obtain the single growth parameter $w$ of Gallucci and Quinn (1979). The parameter is estimated by $\omega=K^{\circ} \cdot L_{\infty}$ and its variance is given as:

$\operatorname{Var}(\omega)=\mathrm{L}_{\infty}^{2} \operatorname{Var}(\mathrm{K})+\mathrm{K}^{2} \operatorname{Var}\left(\mathrm{L}_{\infty}\right)+2 \mathrm{KL} \operatorname{cor}_{\infty} \operatorname{corr}\left(\mathrm{K}, \mathrm{L}_{\infty}\right) \operatorname{Var}(\mathrm{K}) \operatorname{Var}\left(\mathrm{L}_{\infty}\right)$.

Biologically, w can be interpreted as the instantaneous rate of growth at $\mathrm{L}_{0}$. Using a single parameter to represent growt $\mathrm{h}_{2}$ simplifies the testing of growth differences between populations. Normally when comparing two curves the null hypothesis is Ho: $\mathrm{K}_{1} \mathrm{~K}_{2}$ and $\mathrm{L}_{\infty 1} \mathrm{~L}_{\infty 2^{\circ}}$ Interpretations become difficul $\mathrm{t}$ if one equality is rejected and the other is not due to the negative correlation between $L_{\infty}$ and $K$, that is, $L_{\infty}$ and $K$ represent some of the 
same growth properties. By representing growth with w one need deal with only one parameter thereby simplifying the comparisons. In addition $\omega$ tends to be more robust than either $K$ or $L_{\infty}$ to variations in the data (Gallucci and Quinn, 1979).

The environmental data 1 isted in Table 1 was subjected to principal components analysis (PCA) in an effort to reduce the observed variables to a more meaning ful and manageable number of factors without excessive loss of information. PCA is a statistical technique used to anal yze the dependence structure of multivariate data. PCA attempts to locate the hidden factors or components which have generated dependence in the observed variables. In other words, the observed variables are shown to be functions of a smaller number of 1 atent components (Morrison, 1971). These components $c$ an then be used to explain variation in the data. The components produced by PCA are (1) independent and (2) ordered such that the first component accounts for most of the observed variation, the second component accounts for most of the remaining variation and so on. The following definitions are used:

Component - a composite variable which is a linear combination of the original variables such that $c_{i} \approx b_{i 1} x_{1}$ $+b_{i 2} x_{2} \ldots+b_{\text {in }} x_{n}$ where $c$ is the ith component, the $X^{\prime}$ 's are the observed variables, and the b's are the coefficients.

Loading - the degree and direction of the relationship of a variable to its component. They are the coefficients of the component $\left(b_{i}\right)$ and the correlation coefficients $(r)$ between the variables and the component.

Communality - the amount of each variable's variation that is 
accounted for by the components.

Percent variance - the amount of variance in the observed variables accounted for by a component.

The analysis was run on the Pearson product-moment correlation matrix of the environmental parameters (to allow for standardization of the units of measurement) using the CORR, FACTOR and SCORE procedures of SAS79 (Hel wig and Council, 1979). The factors obtained from PCA were then used to anal yze variations in the growth rate $\omega$.

Variations in were analyzed using a step-wise functional regression of $\log _{10}(\omega)$ on the components generated by PCA. The anal ysis was made by calculating the functional regression of $\log _{10}(\omega)$ on Component 1 , taking the residuals and regressing them on Component 2, and so on. The geometric mean functional regression was deemed more suitable than the usual predictive regression because of variability in both $\omega$ and the components, small sample size, and uncertainties about the distribution of the data (Ricker, 1973). Predictive regression yields a regression coefficient (slope) of b While functional regression yields a regression coefficient of $v=b / r$ where $r$ is the correlation coefficient. The standard error of $v$ $\left(S E_{v}\right)$ is the same as the standard error of $b\left(S E_{b}\right)$. $95 \%$ confidence $l$ imits on $v$ are approximated by $v_{2}+2 S E_{v}$ (Ricker, 1973). The logarithmic transformation of was used because the plot of against Component 1 indicated a logarithmic relationship. Estimates of $b, r^{2}$ and $S E_{b}$ were obtained using the GLM procedure of SAS79 (Hel wig and Council, 1979). These estimates were used to calculate $\mathrm{v}$ and its $95 \%$ confidence 1 imits. The significance of the 
, egression is tested by seeing if the confidence limits bracket $v=0$. If not, the null hypothesis Ho: $v=0$ is rejected.

\section{RESULTS}

For each population the mean length at age as determined through length-frequency analysis is given in Table 2. A von Bertal anffy growth model was then fitted to these data excluding the 5 sites acutely affected by pollution. The model parameters determined by the nonlinear curve fitting process plus the growth parameter $\omega$ are presented in Table 3 . Using the $95 \%$ confidence limits around $\omega$ statistically significant growth differences become readily apparent. A regression of $\omega$ on latitude (Figure 3) clearly shows a significant latitudinal trend in growth: growth decreases with increasing latitude. Al though the regression accounts for most of the observed variation in $\omega$ it does not ind ic ate what underlying processes may be responsible for this relationship.

Principal components analysis was used to try and deduce factors which could have contributed to the latitudinal trend and to point out other factors which might be important to growth. These secondary factors could help explain some of the residual variation in growth. The correlation matrix used in the PCA is given in Table 4, and the results of the PCA are shown in Table 5. In order to simplify the table those loading 1 ess than 0.30 have been left out al though all variables contribute to all components to some degree. The first five components have been retained and account for $88 \%$ of the observed variation. Of these, the first three were examined in 
Table 2. Mya arenaria. The age (years), length $\pm_{1}$ standard deviation (mm), and percent of the population for each year class at each site as determined by length-frequency analysis. The sample size for each site is given in parentheses. -: undefined

\begin{tabular}{|c|c|c|c|c|c|c|c|c|}
\hline Age & Length & $\begin{array}{c}\% \text { of } \\
\text { Sample }\end{array}$ & Age & Length & $\begin{array}{c}\% \text { of } \\
\text { Sample }\end{array}$ & Age & Length & $\begin{array}{c}\% \text { of } \\
\text { Sample }\end{array}$ \\
\hline \multicolumn{3}{|c|}{ Quonochontaug Pond-1 (198) } & \multicolumn{3}{|c|}{ Allen Harbor (144) } & \multicolumn{3}{|c|}{ Potato Island (201) } \\
\hline $\begin{array}{l}1.33 \\
2.33 \\
3.33 \\
4.33 \\
5.33 \\
6.33 \\
7.33\end{array}$ & $\begin{array}{l}23.9 \pm 2.1 \\
30.7 \pm 2.1 \\
38.3 \pm 1.9 \\
44.9 \pm 1.3 \\
49.6 \pm 1.2 \\
54.2 \pm 1.4 \\
58.6 \pm 1.4\end{array}$ & $\begin{array}{r}33 \\
43 \\
13 \\
7 \\
2 \\
3 \\
1\end{array}$ & $\begin{array}{l}1.85 \\
2.85 \\
3.85 \\
4.85 \\
5.85 \\
6.85 \\
7.85\end{array}$ & $\begin{array}{l}30.0 \pm 1.8 \\
37.7 \pm 2.6 \\
44.5 \pm 1.5 \\
50.4 \pm 1.8 \\
55.2 \pm 1.3 \\
59.7 \pm 1.4 \\
65.8 \pm 1.4\end{array}$ & $\begin{array}{r}1.1 \\
24 \\
15 \\
18 \\
14 \\
8 \\
9\end{array}$ & $\begin{array}{l}2.5 \\
3.5 \\
4.5 \\
5.5 \\
6.5 \\
7.5 \\
8.5\end{array}$ & $\begin{array}{l}25.3 \pm 0.7 \\
30.9 \pm 1.3 \\
34.6 \pm 1.6 \\
39.2 \pm 1.5 \\
43.7 \pm 1.0 \\
47.1 \pm 0.8 \\
49.4 \pm 0.9\end{array}$ & $\begin{array}{r}2 \\
8 \\
25 \\
41 \\
13 \\
6 \\
3\end{array}$ \\
\hline \multicolumn{3}{|c|}{ Watchemoket Cove (90) } & \multicolumn{3}{|c|}{ East Greenwich Cove (192) } & \multicolumn{3}{|c|}{ Robinston (190) } \\
\hline $\begin{array}{l}1.15 \\
2.15 \\
3.15 \\
4.15 \\
6.15 \\
7.15\end{array}$ & $\begin{array}{l}27.6 \pm 2.9 \\
34.8 \pm 2.0 \\
42.4 \pm 1.7 \\
48.2 \pm 2.5 \\
57.1 \pm 1.4 \\
62.5 \pm 1.0\end{array}$ & $\begin{array}{r}24 \\
31 \\
19 \\
11 \\
8 \\
6\end{array}$ & $\begin{array}{r}1.0 \\
2.0 \\
3.0 \\
.4 .0 \\
5.0\end{array}$ & $\begin{array}{l}20.8 \pm 3.5 \\
30.8 \pm 1.0 \\
38.4 \pm 2.8 \\
45.0 \pm 1.5 \\
50.9 \pm 1.1\end{array}$ & $\begin{array}{r}30 \\
9 \\
49 \\
11 \\
3\end{array}$ & $\begin{array}{l}3.67 \\
4.67 \\
5.67 \\
6.67 \\
7.67 \\
8.67\end{array}$ & $\begin{array}{l}37.9 \pm 1.6 \\
42.5 \pm 1.6 \\
47.2 \pm 1.6 \\
51.7 \pm 1.0 \\
54.6 \pm 0.9 \\
57.0 \pm 1.2\end{array}$ & $\begin{array}{r}8 \\
16 \\
41 \\
20 \\
7 \\
4\end{array}$ \\
\hline
\end{tabular}


Table 2. Continued.

\begin{tabular}{|c|c|c|c|c|c|c|c|c|}
\hline Age & Length & $\begin{array}{c}\% \text { of } \\
\text { Sample }\end{array}$ & Age & Length & $\begin{array}{c}\% \text { of } \\
\text { Sample }\end{array}$ & Age & Length & $\begin{array}{l}\% \text { of } \\
\text { Sample }\end{array}$ \\
\hline Quonochontaug & ntaug Pond-2 & $(146)$ & Bourne & (187) & & Goose & e Cove $(101)^{a}$ & \\
\hline $\begin{array}{r}2.15 \\
3.15 \\
4.15 \\
5.15 \\
6.15 \\
7.15 \\
8.15 \\
9.15 \\
10.15\end{array}$ & $\begin{array}{l}33.7 \pm 2.7 \\
41.6 \pm 2.0 \\
49.0 \pm 1.3 \\
55.1 \pm 1.8 \\
60.2 \pm 1.0 \\
65.8 \pm 1.3 \\
70.5 \pm 0.8 \\
73.5 \pm 0.8 \\
79.0 \pm 1.1\end{array}$ & $\begin{array}{r}41 \\
28 \\
6 \\
6 \\
4 \\
6 \\
4 \\
3 \\
4\end{array}$ & $\begin{array}{l}1.15 \\
2.15 \\
3.15 \\
4.15 \\
5.15 \\
6.15 \\
7.15 \\
8.15 \\
9.15\end{array}$ & $\begin{array}{l}22.7 \pm 2.2 \\
30.6 \pm 2.4 \\
40.8 \pm 2.4 \\
48.2 \pm 2.3 \\
54.4 \pm 1.3 \\
58.9 \pm 1.5 \\
64.3 \pm 2.1 \\
70.5 \pm 1.3 \\
75.7 \pm 2.0\end{array}$ & $\begin{array}{r}8 \\
5 \\
14 \\
27 \\
10 \\
9 \\
12 \\
8 \\
3\end{array}$ & $\begin{array}{r}3.0 \\
4.0 \\
5.0 \\
6.0 \\
7.0 \\
8.0 \\
9.0 \\
10.0 \\
11.0\end{array}$ & $\begin{array}{l}24.1 \pm 1.9 \\
34.3 \pm 3.8 \\
36.4 \pm 4.1 \\
39.6 \pm 3.2 \\
46.6 \pm 9.8 \\
47.7 \pm 17.2 \\
55.2 \pm 6.9 \\
61.5 \pm 2.1 \\
59.5 \pm 5.8\end{array}$ & $\begin{array}{r}7 \\
12 \\
25 \\
23 \\
5 \\
17 \\
6 \\
2 \\
4\end{array}$ \\
\hline \multicolumn{3}{|c|}{ Saugatucket River (140) } & \multicolumn{3}{|c|}{ West Falmouth (183) } & Long & Cove, Searsport & (152) \\
\hline $\begin{array}{l}2.0 \\
2.6 \\
3.0 \\
3.8 \\
4.8 \\
5.8 \\
7.0 \\
8.0 \\
9.0\end{array}$ & $\begin{array}{l}29.0 \pm 1.3 \\
33.8 \pm 0.9 \\
37.6 \pm 1.6 \\
43.3 \pm 2.2 \\
48.9 \pm 1.5 \\
52.8 \pm 1.1 \\
56.1 \pm 0.7 \\
60.0 \pm 1.2 \\
64.5 \pm 1.2\end{array}$ & $\begin{array}{r}2 \\
5 \\
9 \\
42 \\
7 \\
12 \\
6 \\
6 \\
3\end{array}$ & $\begin{array}{l}1.15 \\
2.15 \\
3.15 \\
4.15 \\
5.15 \\
6.15 \\
7.15 \\
8.15 \\
9.15\end{array}$ & $\begin{array}{l}28.6 \pm 2.6 \\
38.8 \pm 2.6 \\
45.2 \pm 1.5 \\
53.3 \pm 2.9 \\
61.6 \pm 1.5 \\
68.2 \pm 1.9 \\
73.4 \pm 1.7 \\
78.8 \pm 1.4 \\
84.5 \pm 2.6\end{array}$ & $\begin{array}{r}9 \\
3 \\
2 \\
27 \\
8 \\
20 \\
7 \\
5 \\
1\end{array}$ & $\begin{array}{r}6.2 \\
7.2 \\
8.2 \\
9.2 \\
10.2 \\
11.2 \\
12.2 \\
13.2 \\
14.2\end{array}$ & $\begin{array}{l}38.0 \pm 0.6 \\
41.5 \pm 1.4 \\
44.9 \pm 1.0 \\
47.2 \pm 0.6 \\
49.9 \pm 1.0 \\
53.0 \pm 1.2 \\
55.3 \pm 0.7 \\
57.0 \pm 0.8 \\
59.0 \pm 0.9\end{array}$ & $\begin{array}{r}2 \\
3 \\
6 \\
5 \\
14 \\
15 \\
11 \\
10 \\
18\end{array}$ \\
\hline
\end{tabular}

Ages determined by counting shell rings 
Table 2. Continued.

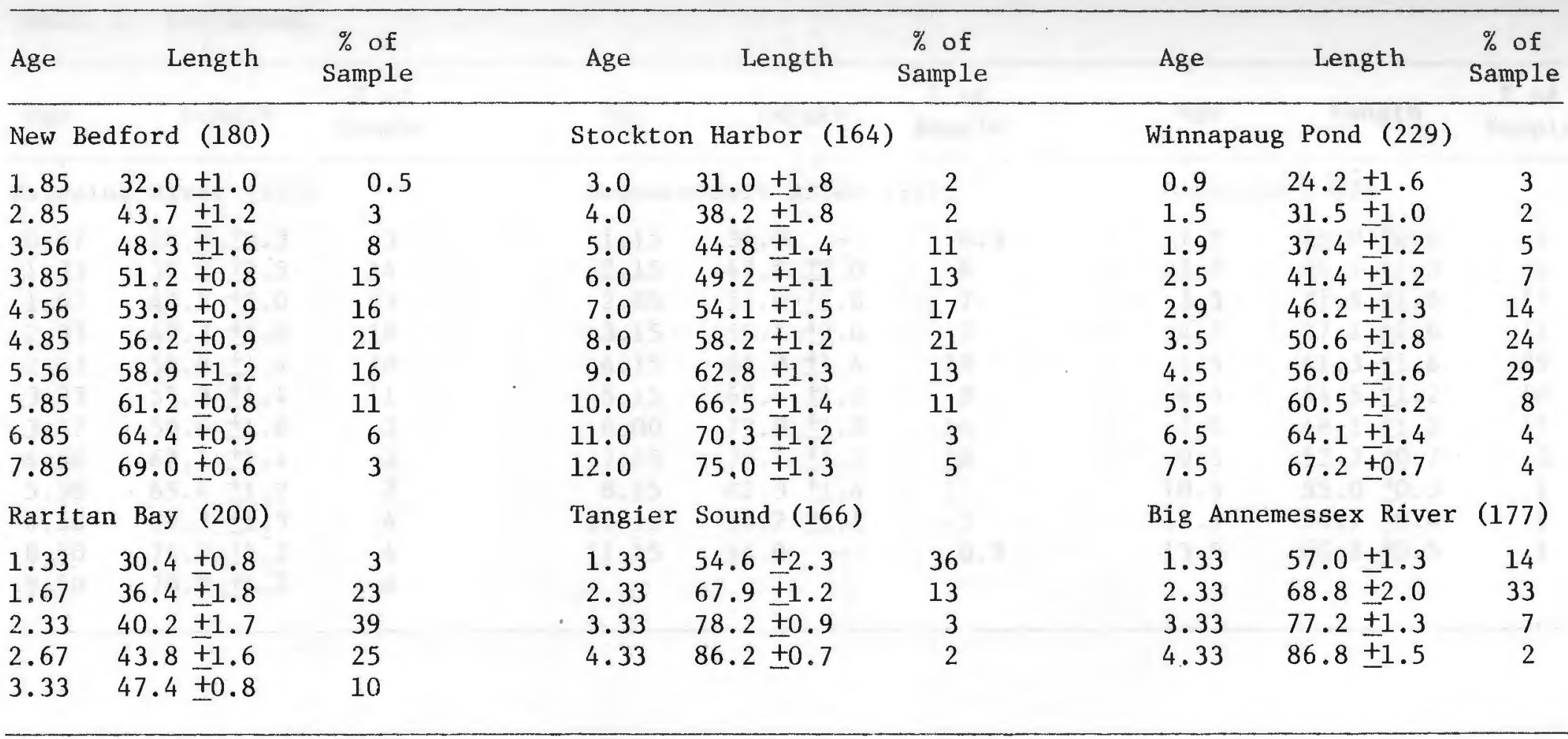


Table 2. Continued.

\begin{tabular}{|c|c|c|c|c|c|c|c|c|}
\hline Age & Length & $\begin{array}{c}\% \text { of } \\
\text { Sample }\end{array}$ & Age & Length & $\begin{array}{c}\% \text { of } \\
\text { Sample }\end{array}$ & Age & Length & $\begin{array}{c}\% \text { of } \\
\text { Sample }\end{array}$ \\
\hline Navesink & River (103) & & Coonan & sett River & (124) & Portland & $(367)$ & \\
\hline 0.67 & $26.0 \pm 2.3$ & 3 & 1.15 & $34.0-$ & 0.5 & 1.5 & $19.0 \pm 0.8$ & 1 \\
\hline 1.33 & $35.2 \pm 2.5$ & 14 & 2.15 & $42.8 \pm 2.0$ & 4 & 2.5 & $26.7 \pm 1.3$ & 4 \\
\hline 1.67 & $42.5 \pm 2.0$ & 23 & 2.85 & $52.0 \pm_{1.0}$ & 7 & 3.5 & $31.5 \pm_{1} .6$ & 17 \\
\hline 2.33 & $47.3 \pm 1.8$ & 18 & 3.15 & $56.1 \pm 2.0$ & 7 & 4.5 & $37.1 \pm 1.6$ & 21 \\
\hline 2.67 & $51.8 \pm 1.4$ & 10 & 4.15 & $64.0 \pm 1.4$ & 18 & 5.5 & $41.3 \pm_{1} .6$ & 29 \\
\hline 3.33 & $55.3 \pm 1.4$ & 11 & 5.15 & $69.4 \pm 1.2$ & 9 & 6.5 & $44.5 \pm 1.2$ & 10 \\
\hline 3.67 & $59.6 \pm 1.6$ & 2 & 6.00 & $72.8 \pm 1.2$ & 16 & 7.5 & $48.1 \pm 1.2$ & 15 \\
\hline 4.50 & $62.1 \pm_{1.4}$ & 2 & 7.15 & $77.4 \pm 1.2$ & 18 & 9.5 & $52.7+0.7$ & 3 \\
\hline 5.50 & $65.4 \pm 1.2$ & 2 & 8.15 & $82.3 \pm 1.4$ & 17 & 10.5 & $55.0 \pm 0.5$ & 1 \\
\hline 6.50 & $69.7 \pm 1.5$ & 4 & 10.15 & $88.2+1.1$ & 5 & 11.5 & $56.7 \pm 0.4$ & 1 \\
\hline 8.50 & $74.7 \pm_{1.2}$ & 4 & 11.15 & $94.0-$ & 0.5 & 13.5 & $60.2 \pm 0.5$ & 1 \\
\hline 9.50 & $78.0 \pm 1.2$ & 6 & & & & & & \\
\hline
\end{tabular}


Table 2. Continued.

\begin{tabular}{|c|c|c|c|c|c|c|c|c|}
\hline Age & Length & $\begin{array}{c}\% \text { of } \\
\text { Sample }\end{array}$ & Age & Length & $\begin{array}{c}\% \text { of } \\
\text { Sample }\end{array}$ & Age & Length & $\begin{array}{c}\% \text { of } \\
\text { Sample }\end{array}$ \\
\hline \multicolumn{3}{|c|}{ Perry (180) } & 4.80 & $68.1+2.5$ & 36 & \multicolumn{3}{|c|}{ Janvrin Lagoon (201) } \\
\hline 3.67 & $36.4 \pm 1.5$ & 3 & 5.80 & $75.1 \pm 1.8$ & 13 & 3.5 & $21.0-$ & 0.5 \\
\hline 4.67 & $41.1 \pm_{1.5}$ & 11 & 6.00 & $80.2 \pm 1.1$ & 7 & 4.5 & $26.7 \pm 0.7$ & 3 \\
\hline 5.67 & $47.1 \pm 1.8$ & 29 & 7.00 & $84.7 \pm 0.9$ & 2 & 5.5 & $29.9 \pm 0.9$ & 6 \\
\hline 6.67 & $55.2 \pm 2.3$ & 46 & 8.00 & $88.5+0.6$ & 2 & 6.5 & $32.6 \pm 0.8$ & 11 \\
\hline 7.67 & $62.3+0.8$ & 5 & \multirow{2}{*}{\multicolumn{2}{|c|}{ Deer Isle (318) }} & & 7.5 & $36.2 \pm 1.3$ & 24 \\
\hline 8.67 & $66.9 \pm 0.8$ & 3 & & & & 8.5 & $39.7 \pm 1.0$ & 24 \\
\hline 9.67 & $70.9 \pm 1.9$ & 3 & 3.0 & $25.7 \pm 1.9$ & 4 & 9.5 & $43.8 \pm 1.0$ & 17 \\
\hline Wickford & (203) & & 4.0 & $31.2 \pm 1.1$ & 7 & 10.5 & $47.4 \pm 1.0$ & 11 \\
\hline Wickiord & $(203)$ & & 5.0 & $35.2 \pm 1.3$ & 21 & 11.5 & $50.3 \pm 1.0$ & 3 \\
\hline 0.20 & $7.0-$ & 0.5 & 6.0 & $39.2 \pm 1.3$ & 18 & 12.5 & $54.0^{-}-$ & 0.5 \\
\hline 2.00 & $37.3 \pm 1.1$ & 2 & 7.0 & $42.1 \pm 1.1$ & 9 & & & \\
\hline 2.67 & $48.7 \pm 1.4$ & 4 & 8.0 & $44.6 \pm 1.0$ & 10 & & & \\
\hline 3.00 & $53.9 \pm 1.4$ & 10 & 9.0 & $47.8 \pm 1.0$ & 12 & & & \\
\hline 3.80 & $60.4 \pm 1.8$ & 18 & 10.0 & $51.5 \pm 1.0$ & 9 & & & \\
\hline
\end{tabular}


Table 3. Mya arenaria. Estimates and standard errors for the von Bertalanffy constants.

\begin{tabular}{|c|c|c|c|c|c|c|c|c|c|c|}
\hline $\begin{array}{l}\text { Sit } \\
\text { Cod }\end{array}$ & $\begin{array}{l}\text { e Num- } \\
\text { e ber }\end{array}$ & & $\mathrm{k}$ & & $L_{\infty}$ & & & $\operatorname{Corr}\left(k \cdot L_{\infty}\right)$ & $\omega$ & $\begin{array}{l}95 \% \text { Confidence } \\
\text { Interval on } \omega\end{array}$ \\
\hline TS & 90 & .2530 & $(.0597)$ & 111.05 & $(11.18)$ & -1.188 & $(.263)$ & -.9927 & 29.108 & $25.218-32.997$ \\
\hline AR & 99 & .2740 & $(.0520)$ & 107.13 & $(7.22)$ & -1.440 & $(.268)$ & -.9897 & 29.354 & $26.096-32.612$ \\
\hline NR & 101 & .3016 & $(.0162)$ & 79.69 & $(1.10)$ & -0.718 & $(.095)$ & -.8764 & 24.034 & $22.250-25.819$ \\
\hline$R B$ & 200 & .1829 & $(.0986)$ & 81.50 & $(22.08)$ & -1.450 & $(.558)$ & -.9983 & 14.906 & $13.190-16623$ \\
\hline WP & 228 & .2992 & $(.0114)$ & 73.27 & $(0.89)$ & -0.400 & $(.058)$ & -.9575 & 21.966 & $21.150-22.782$ \\
\hline$Q 1$ & 202 & .1175 & $(.0194)$ & 93.23 & $(9.20)$ & -1.104 & $(.148)$ & -.9936 & 10.954 & $9.656-12.253$ \\
\hline Q2 & 150 & .1069 & $(.0134)$ & 111.00 & $(6.96)$ & -1.205 & (.191) & -.9920 & 11.866 & $10.104-13.628$ \\
\hline SR & 129 & .2119 & $(.0229)$ & 72.34 & $(2.48)$ & -0.445 & $(.225)$ & -.9737 & 15.329 & $13.859-16.799$ \\
\hline WK & 191 & .1811 & $(.0155)$ & 111.80 & $(4.21)$ & -0.436 & $(.127)$ & -.9833 & 20.258 & $18.723-21.793$ \\
\hline CR & 127 & .1997 & $(.0114)$ & 97.75 & $(1.60)$ & -0.990 & $(.143)$ & -.9728 & 19.521 & $17.832-21.209$ \\
\hline $\mathrm{AH}$ & 144 & .0903 & $(.0184)$ & 113.20 & $(13.11)$ & -1.668 & $(.288)$ & -.9967 & 10.222 & $8.217-12.227$ \\
\hline WF & 139 & .0917 & $(.0162)$ & 136.73 & $(14.88)$ & -1.357 & $(.184)$ & -.9964 & 12.538 & $10.129-14.948$ \\
\hline NB & 179 & .1532 & $(.0198)$ & 89.28 & $(4.30)$ & -1.571 & $(.304)$ & -.9922 & 13.678 & $12.309-15.046$ \\
\hline $\mathrm{EG}$ & 196 & .1377 & $(.0425)$ & 91.95 & $(18.20)$ & -0.914 & $(.186)$ & -.9974 & 12.662 & $11.064-11.259$ \\
\hline WC & 89 & .1411 & $(.0246)$ & 07.18 & $(7.37)$ & -1.549 & $(.236)$ & -.9894 & 12.301 & $9.919-14.683$ \\
\hline $\mathrm{PT}$ & 379 & .1468 & $(.0077)$ & 67.91 & $(1.39)$ & -0.836 & $(.122)$ & -.9734 & 9.967 & $9.501-10.438$ \\
\hline $\mathrm{DI}$ & 287 & .1255 & $(.0114)$ & 67.96 & $(2.46)$ & -0.781 & $(.218)$ & -.9911 & 8.533 & $7.896-9.170$ \\
\hline $\mathrm{SH}$ & 159 & .0565 & $(.0083)$ & 135.71 & $(12.34)$ & -0.980 & $(.336)$ & -.9973 & 7.668 & $5.838-9.497$ \\
\hline RS & 182 & .1623 & $(.0287)$ & 73.13 & $(4.52)$ & -0.745 & $(.434)$ & -.9910 & 11.896 & $10.654-13.084$ \\
\hline PI & 196 & .0986 & $(.0248)$ & 81.55 & $(10.78)$ & -0.171 & $(.432)$ & -.9958 & 8.041 & $6.806-9.276$ \\
\hline
\end{tabular}


Figure 3. Mya arenaria. A plot of growth rate versus I atitude. Solid line is the functional regression of the relationship. 


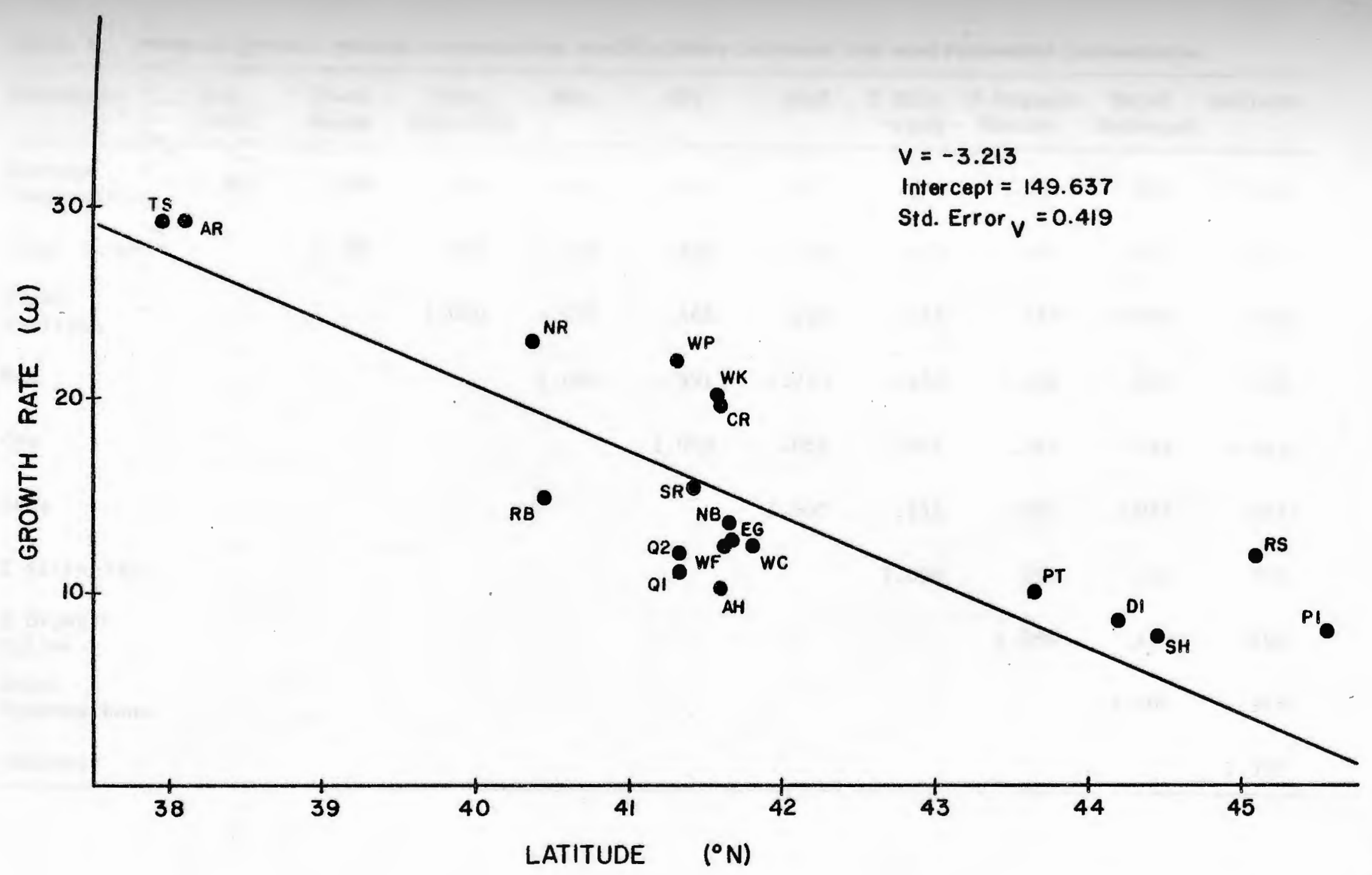


Table 4. Pearson product-moment correlation coefficients between the environmental parameters.

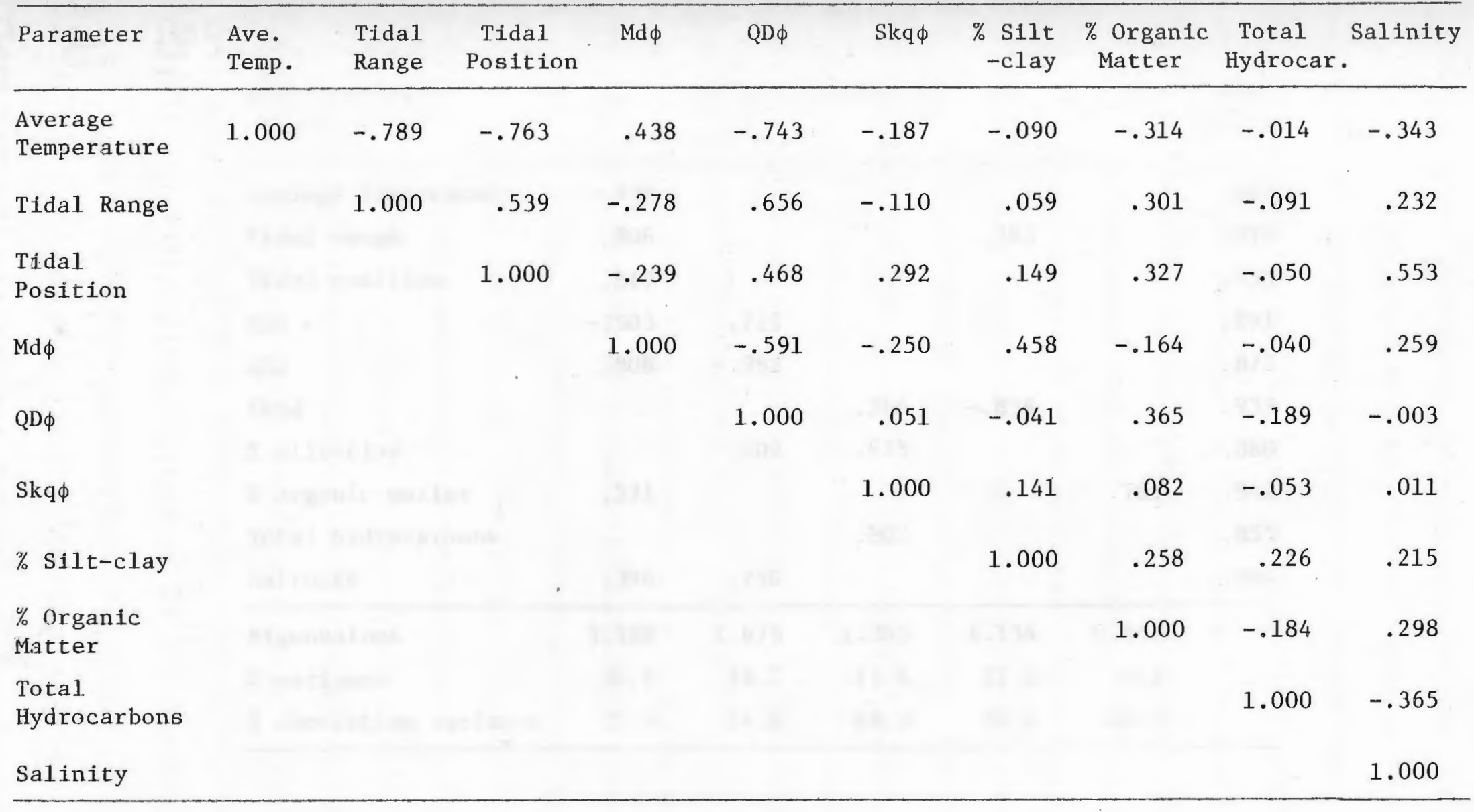


Table 5. Results of the principal components analysis on environinental data. Loadings less than 0.30 have been omitted for clarity.

\begin{tabular}{|c|c|c|c|c|c|c|}
\hline \multirow{2}{*}{$\begin{array}{l}\text { Envi ronmental } \\
\text { Parameter }\end{array}$} & \multicolumn{5}{|c|}{ Principal Components } & \multirow{2}{*}{$\begin{array}{l}\text { Commu- } \\
\text { nality }\end{array}$} \\
\hline & 1 & 2 & 3 & 4 & 5 & \\
\hline Average temperature & -.938 & & & & & .925 \\
\hline Tidal range & .806 & & & .383 & & .819 \\
\hline Tidal position & .817 & & & & & .855 \\
\hline $\operatorname{Md} \phi$ & -.503 & .725 & & & & .891 \\
\hline$Q D_{\dot{\varphi}}$ & .808 & -.382 & & & & .872 \\
\hline $\operatorname{Skq} \phi$ & & & .386 & -.858 & & .933 \\
\hline$\%$ silt-clay & & .609 & .675 & & & .880 \\
\hline$\%$ organic matter & .521 & & & & .765 & .942 \\
\hline Total hydrocarbons. & & & .802 & & & .855 \\
\hline Salinity & .396 & .750 & & & & .840 \\
\hline Etgenvalues & 3.588 & 1.875 & 1.363 & 1.134 & 0.851 & \\
\hline$\%$ variance & 35.9 & 18.7 & 13.6 & 11.3 & 8.5 & \\
\hline$\%$ cumulative variance & 35.9 & 54.6 & 68.3 & 79.6 & 88.5 & \\
\hline
\end{tabular}


greater detail for purposes of reification and further analysis.

The first component is interpreted as representing latitude since the major contributing variables vary with latitude. Average annual temperature, as $\mathrm{might}$ be expected, shows the highest correlation to this component. It decreases with latitude. Tidal range, tidal position, sediment grain size, variability, and organic matter are all positively associated with latitude. To avoid confusion this component will be refered to as 'northness'. The second component is interpreted as siltiness of the sediment. Grain size (negatively correlated) and percent silt-clay (positively correlated) are the main contributing variables. The high correlation of salinity may reflect the role of flocculation and estuarine circulation in the distribution of silts and clays in estuarine sediments (Krumbein and Sloss, 1963; Knaus, 1978). The third component, positively correlated with hydrocarbons and percent silt-clay, is interpreted as representing sedimentary hydrocarbons. The small grain size indicated by the percent silt-clay, and to some degree by positive skewness, can allow for a greater sedimentary surface area for the retention of hydrocarbons (Lytle and Lytle, 1977 ).

The se three components (northness, siltiness, sedimentary hydrocarbons) were then used for the further analysis of growth through step-wise regression. Several sites were omitted from this analysis because missing values precluded the calculation of the component scores. For this analysis the $\log _{10}(\omega)$ was regressed against northness, the residuals from this regression were regressed against siltiness, and residuals from this second regression were 
regressed against sedimentary hydrocarbons. The component scores and residuals are given in Table 6 . The results of the analysis are given in Table 7 and Figures 4,5 and 6. As expected, growth was found to be negatively correlated with northiness. The second regression showed a negative relationship between siltiness and growth. The last regression indicated that growth was negatively correlated with sedimentary hydrocarbons. Much of the deviation about this regression is due to the abnormally high values for Allen Harbor.

\section{DISCUSS ION}

The use of many length-frequency analysis techniques for the determination of age structure and growth is not straightforward. Macdonald and Pitcher (1979) consider the lack of reproducibility as its major drawback. This results from the difficulty in properly distinguishing all the modes in a distribution, especially when multiple spawnings occur or sample size is low. As such, the results of analysis can depend, in 1 arge part, upon the experience of the observer. This is not only evident in the resolution of the distribution mixtures but also in the assignment of ages to the various modes. In this respect, however, even the more sophisticated curve resolving techniques are 1 imited since independent estimates of the number of modes present and length at age are usually required. However, length-frequency analysis has proven itself to be a useful and informative technique and the results obtained here are generally reliable. 
Table 6. Mya arenaria. Component scores for the first three principal components plus the logarithm and residuals of $\omega .-$ : missing value

\begin{tabular}{|c|c|c|c|c|c|c|}
\hline $\begin{array}{l}\text { Site } \\
\text { Code }\end{array}$ & $\begin{array}{l}\text { North- } \\
\text { ness }\end{array}$ & $\begin{array}{l}\text { Silti- } \\
\text { ness }\end{array}$ & $\begin{array}{l}\text { Sedimentary } \\
\text { Hydrocarbons }\end{array}$ & $\log \omega$ & $\begin{array}{l}\text { lst Resid- } \\
\text { ual of } \omega\end{array}$ & $\begin{array}{l}\text { 2nd Resid- } \\
\text { ual of } \omega\end{array}$ \\
\hline NR & -0.701 & 0.187 & -0.525 & 1.138 & .151 & .183 \\
\hline $\mathrm{RB}$ & -0.471 & 0.691 & -0.380 & 1.173 & -.018 & .070 \\
\hline$W P$ & -0.619 & 0.508 & -0.846 & 1.342 & .126 & .194 \\
\hline Q1 & -0.536 & 0.257 & -1.080 & 1.040 & -.163 & -.123 \\
\hline Q2 & -0.736 & 1.305 & -0.598 & 1.074 & -.161 & -.004 \\
\hline SR & -0.558 & -1.352 & 1.023 & 1.186 & -.020 & -.160 \\
\hline WK & -0.065 & 0.350 & -0.689 & 1.307 & .079 & .185 \\
\hline CR & -1.065 & -1.111 & -0.259 & 1.290 & .001 & -.112 \\
\hline AH. & -0.483 & 2.473 & 2.864 & 1.010 & -.184 & .103 \\
\hline WF & -0.431 & -1.746 & 0.518 & 1.095 & -.087 & -.272 \\
\hline $\mathrm{NB}$ & -0.428 & -0.742 & 1.316 & 1.136 & -.048 & -.120 \\
\hline $\mathrm{EG}$ & -0.651 & -0.239 & -0.910 & 1.102 & -.119 & -.134 \\
\hline $\mathrm{BN}$ & -0.146 & -0.008 & -0.739 & - & - & - \\
\hline $\mathrm{PT}$ & 0.602 & 0.402 & 0.427 & 0.997 & -.016 & .040 \\
\hline $\mathrm{DI}$ & 1.175 & 0.721 & -0.094 & 0.931 & .012 & .103 \\
\hline GC & 1.165 & -1.152 & 0.220 & - & - & - \\
\hline SP & 1.391 & $0.25+7$ & 0.900 & - & - & - \\
\hline $\mathrm{SH}$ & 1.291 & -1.047 & 0.953 & 0.885 & -.016 & -.121 \\
\hline PY & 1.380 & 0.643 & -1.636 & - & - & - \\
\hline RS & 1.824 & -0.309 & -0.485 & 1.074 & .262 & .239 \\
\hline JL & -0.042 & 0.729 & 0.082 & - & - & - \\
\hline PI & 1.328 & 0.145 & -0.452 & 0.905 & .011 & .038 \\
\hline
\end{tabular}


Table 7. Mya arenaria. Results of the stepwise regression of growth ( $\omega$ ) on the first three principdl components. The slope of the predictive regression (b) can be found by $b=v \cdot r$

\begin{tabular}{|c|c|c|c|c|}
\hline Regression & $\mathbf{r}$ & Intercept & $\mathrm{v}=\mathrm{slope}$ & $\begin{array}{l}\text { Approximate } 95 \% \\
\text { Confidence Limits }\end{array}$ \\
\hline $\log _{10}(\omega)$ vs Northness & .693 & 1.1137 & -.1653 & $-.2269<v<-.1037$ \\
\hline 1st residual vs Siltiness & .184 & -0.0112 & -.1116 & $-.1682<v<-.0549$ \\
\hline 2nd residual vs Sedimentary Hydrocarbons & .217 & 0.0065 & -.1472 & $-.2214<v<-.0730$ \\
\hline
\end{tabular}


Figure 4. Mya arenaria. A plot of the common logarithm of the growth rate versus the first principal component - northness. Solid line is the functional regression of the relationstip. 


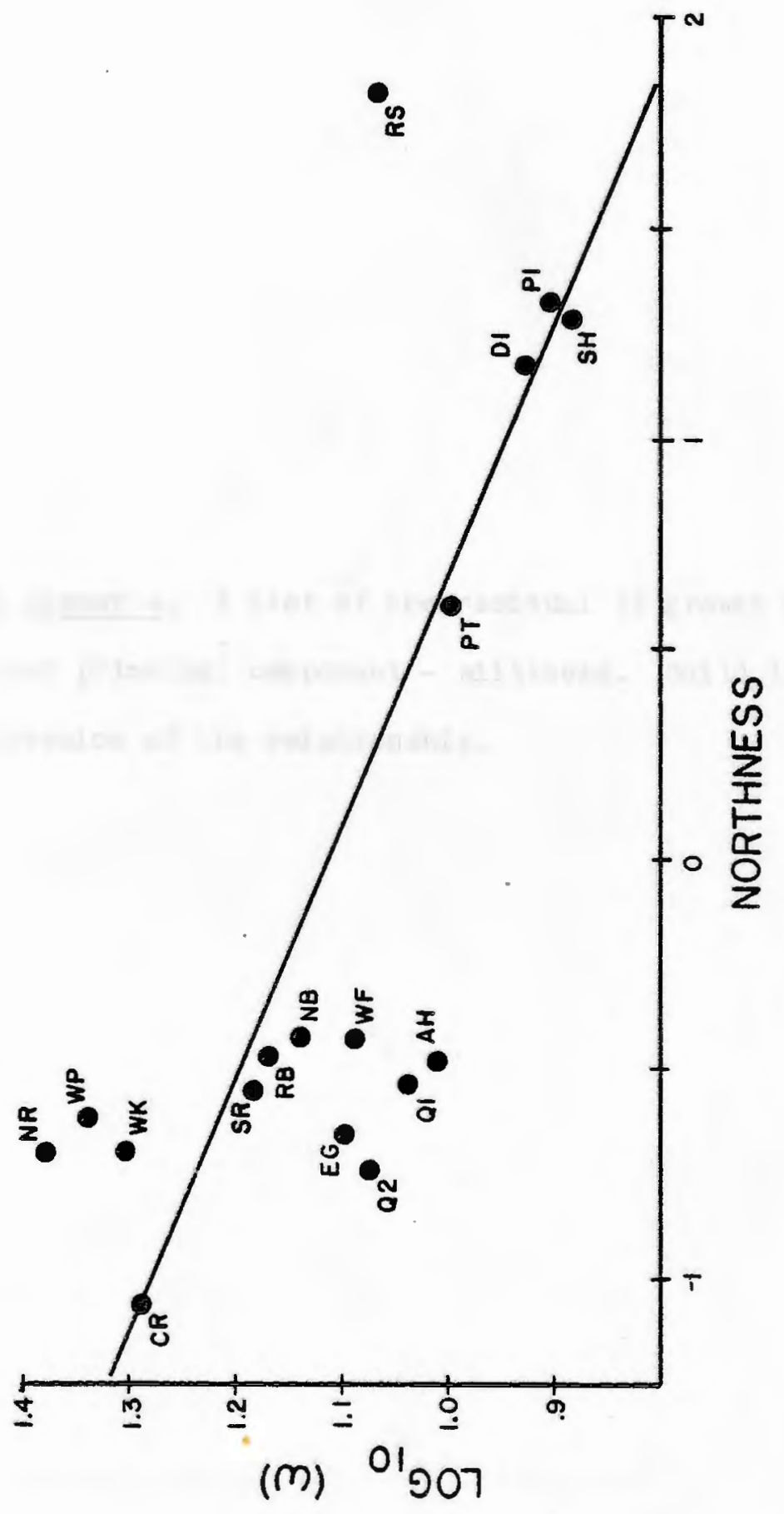


Figure 5. Mya arenaria. A plot of the residual of growth rate versus the second principal component - siltiness. Solid line is the functional regression of the relationship. 


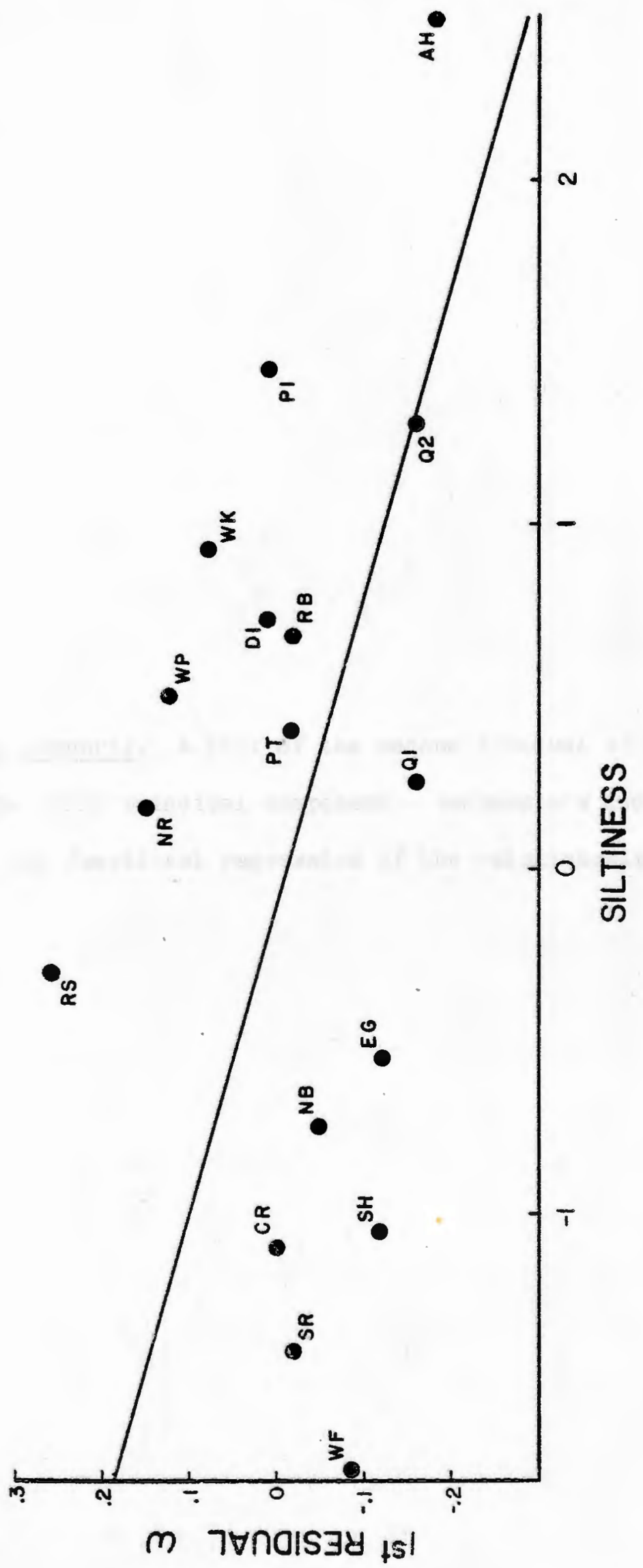


Figure 6. Mya arenaria. A plot of the second residual of growth rate versus the third principal component - sedimentary hydrocarbons. Solid line is the functional regression of the relationship. 


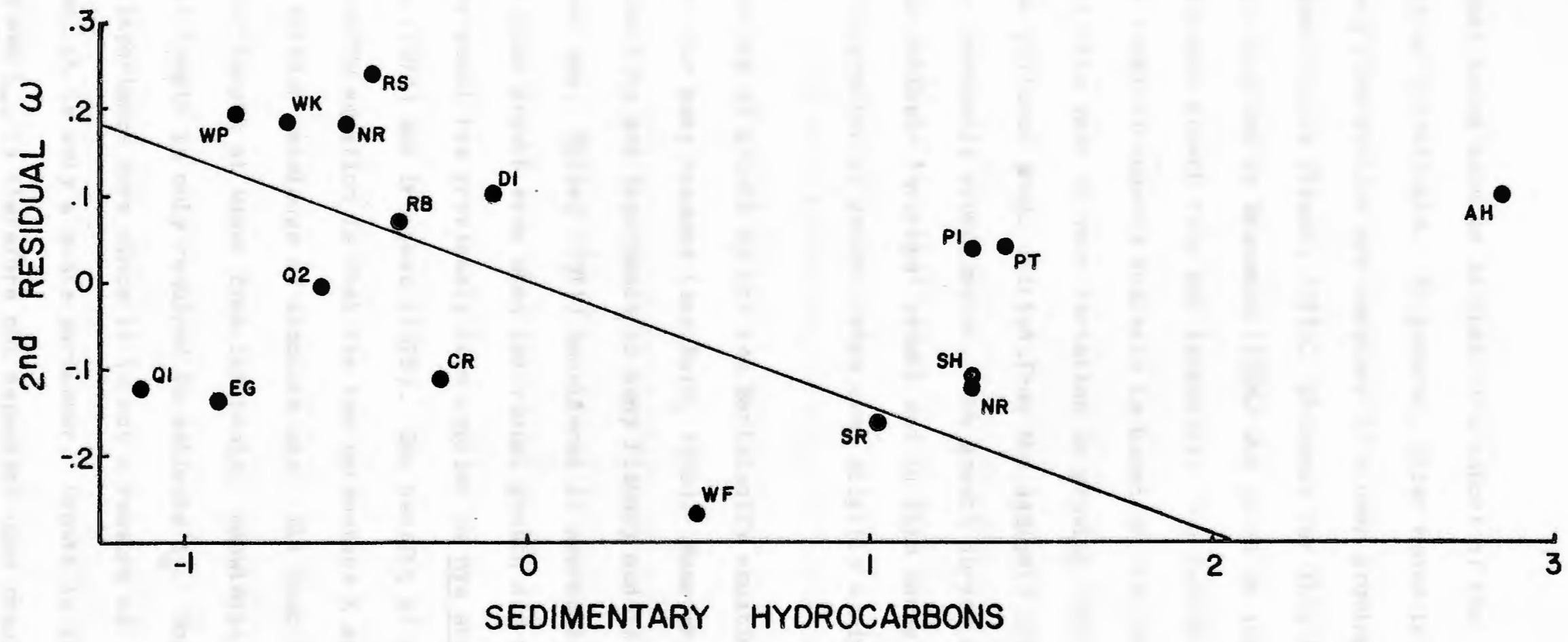


The growth being modeled is that of a cohort of the population, not of individuals. In general, older modes in a length-frequency distribution are composed of slower growing but longer lived individuals (Tesch, 1971). Evidence for this trend in Mya arenaria is supplied by Newcombe (1936) who found an inverse relationship between growth rate and longevity. The determination of growth through length-frequency analysis is based on the assumption that there is little year to year variation in growing conditions. Except in those polluted areas omitted from the analysis this assumption was reasonably approximated. The growth curves obtained are designed to estimate 'average' growth and in this sense they represent an integration of growth rates over slightly varing conditions.

The modeling of growth by the von Bertal anffy equation has been criticized for many reasons (see Roff, 1980). However, its general applicability and importance to many fishery models have led to its continued use. Dickey (1971) considered it appropriate for modeling population growth even when individual growth did not fit the model. The model has previously been applied to Mya arenaria by Munch-Petersen (1973) and Brouseau (1978). One benifit of applying the von Bertalanffy equation is that the two parameters $K$ and $L$ can be determined without knowledge of absolute age. All that is needed are estimates of length at known time intervals. Knowledge of absolute age at length is only required to estimate $t_{0}$. However, $t_{0}$ is of less importance here since it is not a measure of growth. Indeed, it is only a scale parameter. Growth in this study, as measured by $\omega=K \cdot L_{\infty}$, is therefore not dependent upon possible 
inaccuracies in the assigment of ages to modes of the leng th-frequency distribution.

The parameter $w$ proved to be a suitable measure of growth in this study. By reducing the description of growth to a single parameter the discrimination and interpretation of growth rate differences was simplified. In addition, weasily lent itself to further analysis, using more sophisticated techniques, since its simplicity made it more tractable to manipulation and interpretation. As with any parameter, the limits of $\omega$ are dependent upon the quality of the orginal data. In the present study it was impossible to determine how much of the variation in w was due to inaccuracies in the data. However, after three regressions the variation in $\omega$ due to errors of measurement was approaching a 'significant' proportion of the remaining total variation and further regressions would have been suspect.

The observed relationship between latitude and growth is not surprising, especially considering the range of temperatures reflected in the data. Increasing growth would be expected at higher temperatures due to temperature's direct effect on metabolism and length of the growing season (Brouseau, 1979). In addition, with increasing temperature Mya is found lower intertidally or even subtidally, thereby increasing its daily feeding period. However, Belding (1930), Dow and Wall ace (1961), Newcombe and Kessler (1936), and Swan (1952) have stated that local rydrologic and edaphic conditions are more important than temperature in affecting growth; and previous studies have failed to firmly establish such a latitud inal relationship. Newcombe (1936) noticed growth differences 
between three widely separated sites which he attributed to temperature differences. Turner (1948) made a similar observation also based on three areas. Brouseau (1978) showed a tendency for populations in Massachusetts to grow faster than more northernly populations but the relationship was not definite. Each of these studies suffered from two deficiencies: (1) small sample size and (2) limited geographical range. Under these conditions variations in growth due to local conditions can mask any latitudinal trends. The wide variation of points around the regression line in Figure 3 gives evidence for this.

Principal components analysis proved to be useful in the further detailed analysis of growth. PCA produced a smaller number of meaning ful variables, which were easily interpretable, and when used for further analysis produced lucid and rational results.

The first component, northness, correlated well with growth. Again this is not surprising. Temperature had the highest loading for this component and its influence on growth has al ready been discussed. Tidal position, as mentioned, is a secondary result of temperature variations. As with many factors, the components produced by PCA represent an integration of effects and the correlation between growth and northness may al so be dependent upon factors other than temperature. The increase in tidal range with northness, due to the large tides of the Gulf of Maine and the Bay of Fundy represents to some degree an increase in tidal current. Belding (1930) considered current the most important factor pertaining to growth. Current, in turn, can also influence edaphic conditions. Hence a coarse but variable grain size distribution is 
associated with northness. The coarser sediments found toward the north are also a reflection of their glacial origins; and they are beneficial in their ow right since they allow for ample water percolation, drainage and exchange (Dow and Wallace, 1961; Swan, 1952). Within northness, then, there are two sets of opposing conditions which influence growth. Temperature is positively associated with growth while current and sediment characteristics are negatively associated with growth. Since northness is itself negatively correlated with growth it must be concluded that the effects of temperature are overriding and dominant.

The relationship between northness and $\omega$ was logarithmic in nature. Since temperature dominates the relationship this result is reasonable. The effect of temperature on metobolic systems is known to be exponential in nature (Gunter, 1957). What requires explanation is the 1 inear relationship between growth and latitude. It is felt that the addition of the two Maryland sites in the growth-latitude graph unjustly extends the relationship since the large change in latitude may not be accompanied by equally 1 arge changes in ecological conditions. In this case northness should be a more proper representation of the geographical variation in conditions than is 1 atitude.

The effect of the second component, siltiness, on growth al so represents an integration of processes. In small quantities silt and clay help to stablize surface sediments (Kellogg, 1905) but in large quantities they become detrimental. Sanders (1958) found that the distribution of filter feeders, in general, was limited by the silt-clay content of the sediment. Studies with Mya have shown that 
excessive siltation can reduce feeding, through clogging of the gills (Belding, 1930), or lead to complete smothering and death (Wilton and Wilton, 1929; Dow and Wal ace, 1961). Silty sediments al so tend to be fairly consolidated and reduced growth has been observed in such sediments (Swan, 1952; Dow and Wallace, 1961). Silt can easily become trapped between the shell and mantle, with a consequent interruption of growth (Shuster, 1951). Small grain size is al so an indication of a poor current regime, itself a contributing factor to reduced growth. The negative correlation found between siltiness and growth is, therefore, logical and consistant with previous reports. Sedimentary hydrocarbons, the third component derived from the PCA, was al so negatively associated with growth. Many studies have shown that the growth of Mya is adversely affected by the presence of petroleum hydrocarbons (Dow, 1975; Dow and Hurst, 1975; Gilfillan and Vandermeul en, 1978; Gilfillan et al., 1976; Appeldoorn, 1980). Hydrocarbon pollution can adversely affect growth through direct toxicity, smothering, and sediment compaction.

The components identified through PCA have been shown to influence growth. However, these should not be considered the only factors. PCA is 1 imited by the input data and can only reflect the factors represented by that data. In the present study no direct measurements were made on current flow, food supply, and a number of other important factors. Estimates of tidal range, sediment size, etc. can account for only some of these factors. In general the study supported the use of PCA for the analyis of ecological systems. The three components identified accounted for much of the growth differences between the sites and the component loadings reveal ed the 
integration of processes within each component.

ACKNOWLEDGEMENTS The author wishes to express his gratitude to those people who assisted in clam collection, particularly R.L. Dow, M. Richards, J.M. Hickey, M.L.H. Thomas, and M. Worobec; and to those people who were involved in sample processing, notably R.S. Brown, J. Keller, A. Miller, S. Polofsky, C. Brown and E. Frankl in. S.B. Saila, A.N. Sastry, and R.C. Bullock reviewed the manuscript. Financial support for sample collection was provided by a grant from the American Petroleum Institute to Dr. Saila. 


\section{LITERATURE CITED}

American Society for Testing Materials: Grain-size analysis of soils. D422-63. A.S.T.M. Standards 11, 205-216 (1963) Appeldoorn, R.S.: The response of population growth rate in the soft-shell clam, Mya arenaria to the onset and abatement of pollution. Ph.D. Thesis. University of Rhode Is $l$ and 1980

Beaven, G.F.: Temperature and salinity of surface water at Solomons, Maryl and. Che sapeake Sei. 1, 2-11 (1960)

Belding, D. L.: The soft-shelled clam fishery of Massachusetts. Mar. Fish. Ser. Div. Fish Game Mass. 1, $1-65(1930)$

Brousseau, D. J.: Anal ysis of growth rate in Mya arenaria using the von Bertal anffy equation. Mar. Biol. 51, $221-227$ (1979)

Brown, R.S., R.E. Wolke, C.W. Brown, and S.B. Saila:

Hydrocarbon pollution and the prevlence of neoplasia in New England soft-shell clams (Mya arenaria). In: Animal s as Monitors of Environmental Pollutants, pp 41-51. Ed. by F.M. Peters, Washington, D.C.: Nat. Acad. Sei. 1979 Buchanan, J.: Sediments. In: Methods for the Study of Marine Benthos, pp 30-51. Ed. by N.A. Holme and A. D. McIntyre, Oxford: Blackwell Seientific Publications 1971

Cloern, J.E., and F.H. Nichols: A von Bertal anffy growth model with a seasonally varying coefficient. J. Fish. Res. Bd Can. 35, 1479-1882 (1978) 
Dickie, L. M.: Addendum: mathematical models of growth.

In: Methods for Assessment of Fish Production in Fresh

Waters, pp 120-123. Ed. by W.E. Ricker, Oxforò: Bl ackwell

Scientific Publications 1971

Dow, R.L.: Reduced growth and survivial of clams transplanted to an oil spill site. Mar. Pollut. Bull. 6, 124-125 (1975) Dow, R.L., and J.W. Hurst, Jr.: The ecological, chemical, and histopathological evaluation of an oil spill site. Part I. Ecological studies. Mar. Pollut. Bull. 6, 164-166 (1975) Dow, R.L., and D.E. Wallace: The soft-shell clam industry of Maine. Circ. Fish Wilfl. Serv., Wash. 110, 1-36 (1961)

Gallucci, V.F., and T.J., Quinn: Reparameterizing, fitting, and testing a simple growth model.

Trans. Am. Fish. Soc. 108, 14-25 (1979)

Gilbert, M.A.: Growth rates, longevity and maximum size of Macoma balthica (L.). Biol. Bull.mar. bio. lab., Woods Hole 145, 119-126 (1973)

Gilfillan, E.S., D. Mayo, S. Hanson, D. Donov an and L.C. Jiang: Reduction in carbon $f l u x$ in Mya arenaria caused by a spill of No. 6 fuel oil. Mar. Biol. 37, $115-123(1976)$

Gilfillan, E.S., and J.H. Vandermeulen: Alternations in growth and physiology of soft-shell clams, Mya arenaria, crronically oiled with Bunker C from Chedabucto Bay, Nova Scotia, 1970-76. J. Fish. Res. Bd Can. 35, 630-636 (1978) Gunter, G.: Temperature. In: Treatise on Marine Ecology and Paleoecology, Vol. 1, Ecology, Mem. geol. Soc. Am. 67, pp 
159-18 . Ed. by J.W. Hedgepath, Boulder, Colorado:

Geological Society of America 1957

Helwig, J. T., and K.A. Council: SAS User's Guide. 1979

Edition, 494 po. Raleigh, North Carolina: SAS Institute

Inc. 1979

Hicks, S.D.: Physical oceanograhpic studies of Narragansett

Bay, 1957 and 1958.

Spec. scient. Rep. U.S. Fish. Wilfl. Serv. 457, 1-30 (1963)

Jeffries, H.P.: Environmental characteristics of Raritan Bay,

a polluted estuary. Limnol. Oceanogr. 7, 21-31 (1962)

Kellogg, J.L.: Conditions governing existence and growth of

the soft clam. Report of the special commission for the

investigation of the lobster and the soft-shell clam.

Rept. Comm. year ending June 30, 1903.

U.S. Govt. Print. Office 29, 195-224. (1905).

Knauss, J.A.: Introduction to Physical Oceanography, 338 pp.

Highl ands, New Jersey: Prentice-Hall 1978

Krumbein, W.C., and L.L. Sloss: Stratigraphy and

Sedimentation, 660 pp. San Francisco: W.H. Freeman and

Company 1963

Lytle, J.S., and T.F. Lytle: Sediment hydrocarbons as

environmental indicators in the northeast Gulf of Mexico.

In: Fate and Effects of Petroleum Hydrocarbons in Marine

Ecosystems and Organisms, pp 404-412. Ed. by D.A. Wolfe,

New York: Pergamon Press 1977

Macdonald, P.D.M., and T.J. Pitcher: Age-groups from

si ze-frequency data: a versitile and efficient method of 
analyzing distribution mixtures. J. Fish. Res. Bd Can. 36, 987-1001 (1979)

Marine Research: Charleston study annual report. April 1974 - March 1975, 241 pp. Falmouth, Massachusetts: Marine Research Inc. 1975

Morrison, D.F.: Multivariate Statistical Methods, $415 \mathrm{pp}$.

New York: McGraw-Hill 1976

Munch-Petersen, S.: An investigation of a population of the soft clam (Mya arenaria L.) in a Danish estuary. Meddr Komm n Danm. Fisk. -og Havunders. 7, 47-73 (1973)

National Ocean Survey: Tide Tables 1979: East Coast of North and South America, including Greenland, 293 pp. Rockville, Maryl and: National Oceanic and Atmospheric Administration, National Ocean Survey 1978

Newcombe, C.L.: A comparitive study of the abundance and the rate of growth of Mya arenaria L. in the Gulf of St. Lawrence and Bay of Fundy regions. Ecology 17, 418-428 (1936)

Newcombe, C.L., and H. Kessler: Variations in growth indicies of Mya arenaria L. on the Atlantic coast of North America. Ecology 17, 321-352 (1936)

Pfitzenmeyer, H.T.: Tentative outline for inventory of molluses: Mya arenaria (soft shell clam). Chesapeake Sci. 13, S182-S 184 (1972)

Ricker, W.E.: Linear regressions in fishery research.

J. Fish. Res. Bd Can. 30, 409-434 (1973)

Roff, D.A.: A motion for the retirement of the von 
Bertalanffy function. Can. J. Fish. Aquat. Sci. 37 , $127-129(1980)$

Sameoto, D.D.: Yearly respiration rate and estimated energy budget for Sagitta elegans. J. Fish. Res. Bd Can. 29, 987-996 (1972)

Sanders, H.L.: Benthic studies of Buzzard's Bay. I. Animal-sediment relationships. Limnol. Oceanogr. 3, $245-258(1958)$

Shorey, W.K.: Macrobenthic ecology of a sawd ust-bearing substrate in the Penobscot River estuarty (Maine). J. Fish. Res. Bd Can. 30, $493-497$ (1973)

Shuster, C.N.: On the formation of midseason checks in the shell of Mya. Anat. Rec. 111, 543 (1951)

Swan, E.F.: The growth of the clam Mya arenaria as affected by the substratum. Ecology $33,530-534$.

Tesch, F.W.: Age and growth. In: Methods for Assessment of Fish Production in Fresh Waters, pp 98-120. Ed. by W.E. Ricker, Oxford: "Blackwell Scientific Publications 1971

Thomas, M.L.H.: Comparison of oiled and unoiled intertidal communities in Chedabucto Bay, Nova Scotia. J. Fish. Res. Bd Can. 35, 707-716 (1978)

Turner, H.J., Jr.: Report on investigations of the propagation of the soft-shell clam. Mya arenaria. Rep. Invest. Shellfish. Mass 1, 3-9 (1948)

Wilton, M.H., and H.I. Wilton: Conditions affecting the growth of the soft shell clam, Mya arenaria L. 
Contr. Can. Biol. Fish. 4, 81-93 (1929) 
THE RESPONSE OF POPULA TION GROWTH RATE IN THE SOF T-SHELL

CLAM, Mya arenaria, TO THE ONSET AND

ABATEMENT OF POLLUT ION

Richard S. Appeldoorn

Graduate Sohool of Dceanography

University of Rhode Isl and

King ston, R.I. 02881 


\section{ABSTRACT}

Length-frequency anal ysis was used to generate age-length curves for six populations of the soft-shell clam, Mya arenaria, exposed to a sudden pollution event. Five of the populations were each subjected to a single oil spill. The sixth population was subjected to the onset and subsequent abatement of the effluent from a heavy metals mine. With one exception, where no effect was noticed, the onset of pollution was accompanied by a noticeable break in the age-length curve representing a decrease in the population growth rate following the event. At the site where abatement occurred the age-length curve showed a second break indicating the resumption of near normal growth. An attempt is made to relate the severity and persistence of the pollution effect on growth to the degree of deflection in the age-length curve. A method whereby pre-pollution growth $c$ an be estimated is presented and applied to two populations. 


\section{INTRODUCTION}

The need for more information on the effects of discharging pollutants into marine ecosystems has long been recognized. However, only recently has significant progress been made toward this end. Early investigators studied only acute lethal effects, and the variability in the number and reliability of the methods involved led to much confusion (Hyland and Schneider, 1976). With improving methodology there has been an increase in the interest of investigating chronic and sublethal effects (Anderson, 1977). This has been coupled with the recognition that research should be concerned with effects on population processes rather than on individuals (Vanderhorst et al.., 1978). Notable studies involving the long term monitoring of populations following a pollution event are those of the West Falmouth oil spill, the Chedabucto Bay oil spill, and studies of pulp mill effects in Sweeden (Rosenberg, 1976). One major problem in studying the effects of sudden environmental changes is the availability of reliable control data from either measurements made prior to the change or from a suitable control area.

Recently an investigation into the status of soft-shell clam (Mya arenaria) populations and their relationship to various forms of pollution has taken place (Brown et al., 1979). Within the context of this investigation samples were collected from several sites characterized by a sudden change in environmental quality due to the onset or abatement of pollution. Population growth has been one of the parameters studied for each site. The effect of each pollution event on growth was obviously of particular interest. 
The purpose of this paper is primarily to present age-length curves of soft clam populations from the sample sites where a pollution event occurred. Based on a few assumptions these curves can be used to represent growth. It will be shown that a sudden change in the environmental qualtiy resulting from the onset or abatement of pollution is reflected by a shift in the age-length curve. In addition, a method will be presented whereby growth prior to a pollution event may be estimated.

\section{METHODS}

The growth of clams was studied at six sites where a discrete pollution incident (either onset or abatement) occurred. Five of the sites were affected by spills of $v$ arious types of oil. The sixth site was exposed to the effluent from an intertidal heavy metals mine. Table 1 lists the sampling sites and gives a brief characterization of each area. Initial estimates for the extent of pollution are given in Table 2.

Each site was sampled once with the exception of Searsport which was sampled quarterly in 1977 and 1978. $\mathrm{Cl}$ ams were dug using a standard clam hoe. All clams excavated were measured for length to the nearest millimeter using vernier calipers. For Searsport, length data for clams setting after the spill were obtained from Dow ( 1978 , Table 2, p. 47) using ring measurements on live clams from the 1971 year class.

To obtain growth rates clams were aged using length-frequency anal ysis. A single exception was for Goose Cove where shell ring counts were used exclusively to age the clams. For each site the 
Table 1. Description of sampling sites.

\begin{tabular}{|c|c|c|c|c|}
\hline Area & Pollution Event & $\begin{array}{l}\text { Date of } \\
\text { Sampling }\end{array}$ & $\begin{array}{l}\text { Hydrocarbon } \\
\text { Concentration }\end{array}$ & $\begin{array}{l}\text { Sediment } \\
\text { Characteristics }\end{array}$ \\
\hline $\begin{array}{l}\text { Basset's Island } \\
\text { Red Brook Harbor }\end{array}$ & $\begin{array}{l}\text { No. } 2 \text { fuel oil spill from } \\
\text { Bouchard No. } 65 \text {, September } \\
1974\end{array}$ & $5 / 12 / 76$ & 11.4 & Predominantly clean sand \\
\hline $\begin{array}{l}\text { Wild Harbor } \\
\text { North Falmouth, } \\
\text { Massachusetts }\end{array}$ & $\begin{array}{l}\text { West Falmouth oil spill } \\
\text { No. } 2 \text { fuel oil \& detergents } \\
\text { from Florida, September } 1969\end{array}$ & $5 / 3 / 77$ & 47 & Clean coarse sand \\
\hline $\begin{array}{l}\text { Long Cove } \\
\text { Searsport, Me. }\end{array}$ & $\begin{array}{l}\text { No.2 fuel oil \& JP- } 4^{2} \text { jet } \\
\text { fuel spill, March } 1971\end{array}$ & $4 / 15 / 77$ & 58 & $\begin{array}{l}\text { Consolidated sand with } \\
\text { silt \& some gravel \& rock }\end{array}$ \\
\hline $\begin{array}{l}\text { Gleason Cove } \\
\text { Perry, Me. }\end{array}$ & $\begin{array}{l}\text { Crude ofl \& detergents } \\
\text { sp } 111 \text { from Irving } 0 \text { il } \\
\text { Refinery, June } 1974\end{array}$ & $8 / 15 / 78$ & 11 & $\begin{array}{l}\text { Consolidated coarse sand } \\
\text { and mud with rocks in a } \\
\text { patchy distribution }\end{array}$ \\
\hline $\begin{array}{l}\text { Janvrin Lagoon } \\
\text { Madame Is Iand } \\
\text { Chedabucto Bay, } \\
\text { Nova Scotia }\end{array}$ & $\begin{array}{l}\text { Chedabucto Bay ofl spill } \\
\text { Bunker C of } 1 \text { from the } \\
\text { Arrow, February } 1970\end{array}$ & $7 / 18 / 78$ & 38 & Muddy sand with some rocks \\
\hline $\begin{array}{l}\text { Goose Cove } \\
\text { Harborside, Me. }\end{array}$ & $\begin{array}{l}\text { Effluent from a settling } \\
\text { pond of a heavy metals } \\
\text { mine, } 1969-1972\end{array}$ & $7 / 20 / 76$ & -- & $\begin{array}{l}\text { Coarse sand to very consoli- } \\
\text { dated sand with rock \& shell } \\
\text { in a patchy distribution }\end{array}$ \\
\hline
\end{tabular}

IAll hydrocarbon concentrations are for the sediment ( $\mathrm{gg} / \mathrm{g}$ dry weight by GC). Samples were taken at the time of clam collection.

Source: C. Brown (personal communication).

2Originally reported as JP-5 (Gilfillan et al., 1977). 
Table 2. The magnitude of pollution at each site.

Area

Bourne

Wild Harbor

(West Falmouth)

Long Cove

Searsport

Perry

Janvrin Lagoon

Goose Cove
Pollution History

The site was initially covered by ofl. Changing wind and current patterns eventually washed most of the oil out of the area. Hampson \& Moul (1977) reported that some of the oil was still present in certain marsh areas, but little evidence of oil was found at sampling.

A sediment concentration of $590 \mu \mathrm{g} / \mathrm{g}$ (dry wt.) was reported at Site II of the WHOI studies. This site is located up a tidal creek (Wild Harbor River) just below the present sampling location. Later concentrations steadily declined reaching $1 / 3$ of the intial value after 2 years (Sanders, 1970).

The site, located near the inner most of 3 main culverts where oil entered the cove, is equivalent to Station 12 of Mayo et al. (1975) who found an initial concentration of $58 \mu \mathrm{g} / \mathrm{g}$ (dry wt.). At two adjacent stations (11 and 13) sampled the following year the concentration had increased by an order of magnitude. Further contamination was due to oil leaching from saturated sediments upslope.

Crude ofl and detergents initially covered the flat. Little evidence of contamination was found at sampling.

The lagoon was initially covered by $30 \mathrm{~cm}$ of oil. Much of the oil has remained and is periodically.remobilized. Measurements taken 6 years later by Thomas (1978) and Gilfillan \& Vandermeulen (1978) showed average concentrations at thousands of $\mu \mathrm{g} / \mathrm{g}$ (dry wt.). However, these measurements tended to vary by four orders of magnitude. At sampling oil was still abundant, and a slick would form on any depression made on the flat.

During mine operations record levels of 8 metals (Mn 341, Cd 1.7, Cr 29.5, Ni 4.1, Zn 195 , $\mathrm{Pb} \mathrm{55}$, Fe 2471, Co $1.5 \mathrm{ppm}$ ) and extremely high $\mathrm{Cu}$ levels were found in soft clams near the outflow. Levels typically ranged 1 to 2 orders of magnitude above those found in control clams (Dow \& Hurst, 1972). 
leng th-frequencies were plotted a $1 \mathrm{~mm}$ intervals and the modes on the resulting graph were broken down into a series of normal curves by inspection (Peterson Method) (Tesch, 1971; Macdonald and Pitcher, 1979) using a Dupont 310 Curve Resolver. The curve resolver is an analog computer which allows the investigator to break down a complex envelope into its basic components (in this case normal curves) in a graphical fashion. It utilizes function generator channels (10) capable of generating normal curves on a cathode ray tube. The images are then projected on to the length-frequency histogram drawn for each population. The histogram is broken down from left to right (young to old) in the following manner. One channel is switched on and the projected curve is positioned such that its location, width, and height correspond to the left edge of the histogram. The remainder of the histogram is then resolved by successivel y turning on the channels and positioning them such that the envelope projected (formed by the summation of the outputs of all the 'on' channels) matched the outline of the histogram. The optical output gives the observer immediate feedback, and repeated trials can be made quickly by varying the size, shape, position, and number of curves until it is felt that a reasonable 'fit' to the data has been obtained. At this point the output of each channel can be turned on and displayed independently, and its projection can be traced on the histogram. The result of this process is exemplified in Figure 1. From the resulting graphs the mean and standard deviation of each distribution can be obtained (Macdonald and Pitcher, 1979). The mean occurs at the peak and the standard deviation is the half width at $61 \%$ of the height (See curve 4, Figure 1). The curve resolver is also equipped 
F IGURE 1. Leng th-frequency histogram for Janvrin Lagoon with superimposed distributions for each age group as determined with the curve resolver. Solid curves represent age groups. Dashed curves represent the total fitted envelope. The mean plus one standard deviation are shown for the fourth curve. The numbers above represent the percentage of the sample under each curve respectively. 


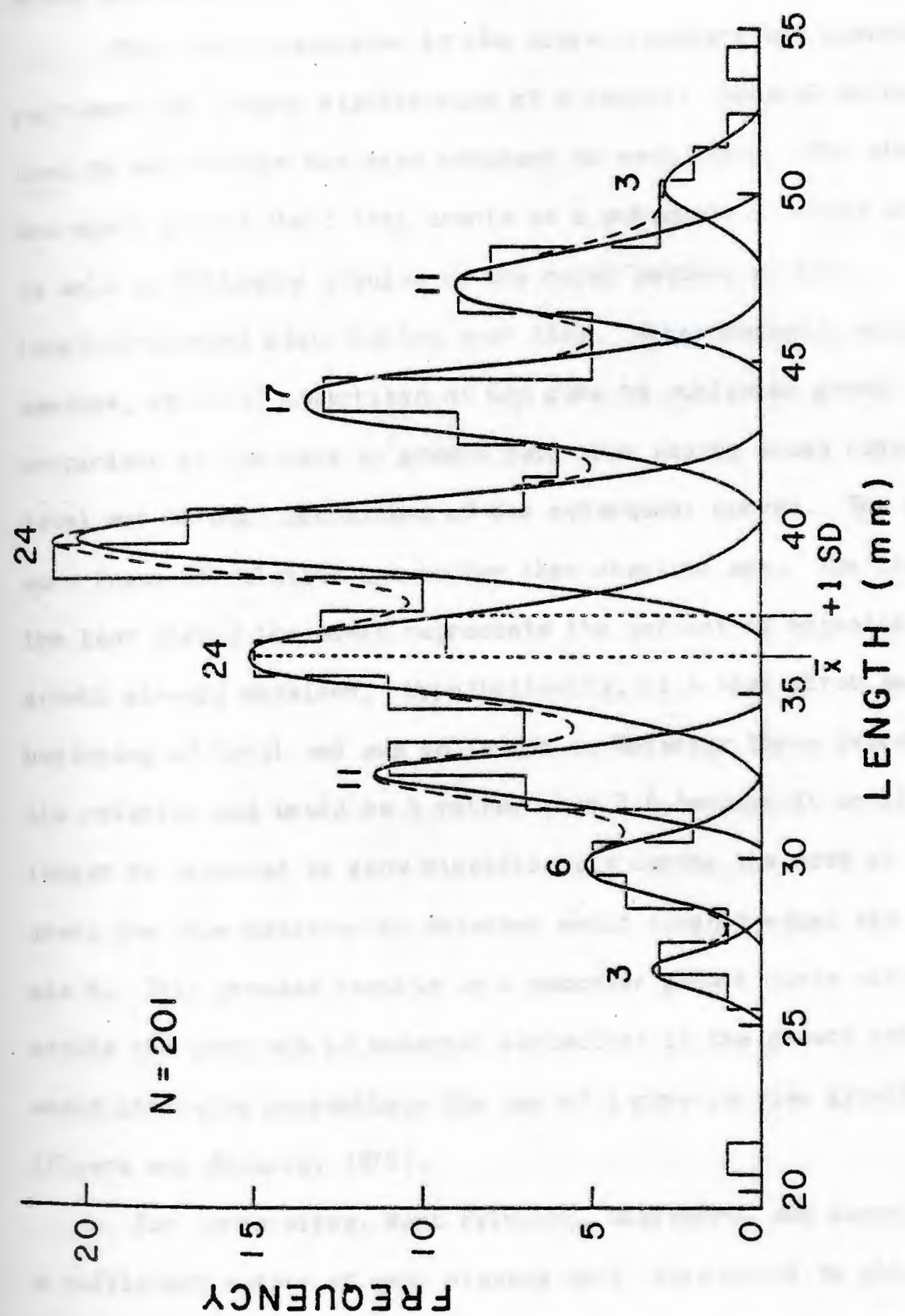


with an integrator which allows one to obtain the percentage of the whole sample under each component curve.

Each curve generated by the above procedure was assumed to represent the length distribution of a cohort. Several methods were used to corroberate the ages assigned to each group. For the Searsport sample shell ring counts on a subsample of clams were used as well as following changes in the modal pattern of the length-frequency distribution over time. Other methods, used for all samples, included comparison of the data to published growth $d a t a$, comparison of the data to growth data from nearby areas (un published data) and through inspection of the subsequent curves. The ages used were those of relative age rather than absolute age. The time beyond the last yearly increment represents the percent of expected yearly growth already obtained. Hypothetically, if a clam first set in the beginning of April and was collected in November three years 1 ater its relative age would be 4 rather than 3.6 because it would no longer be expected to grow significantly during the rest of its third year; the size obtained by November would roughly equal its size at age 4. This process results in a smoother growth curve since it avoids the problems of seasonal variations in the growth rate which would otherwisw necessitate the use of a more complex growth model (Cloern and Nichols, 1978).

For three sites, West Falmoutr, Searsport, and Janvrin Lagoon, a sufficient number of year classes were represented to allow a von Bertal anffy growth curve to be fitted to the data. Only post-spill age classes were used to fit the curve which reduced the number of points available for the analysis. The growth curve was fitted by 
nonl inear regression according to Gallucci and Quinn (1979) using the NLIN procedure of SAS 76 (Barr et al., 1976). This procedure yielded estimates of the parameters for the von Bertal anffy growth equation $L_{x_{m}}\left(1-\exp \left(-K\left(t-t_{0}\right)\right)\right.$ where $t=$ time, Lalength at time $t$, $L_{\text {max }}$ max imum asymptotic length, $K=$ growth constant, and $t_{0} x$ time when $L m 0$.

Using the calculated von Bertal anffy curve the growth rate prior to pollution was estimated. This analysis was based on the assumption that growth follows a fixed schedule or pattern. Growth prior to pollution may be different (i.e. have its own growth schedule) from growth after pollution. It was assumed that the post-pollution growth sohedule was adequately modeled by the calculated von Bertal anffy curve. The pre-pollution growth schedule was then approximated in the following manner. The length (L.1) of the last year class to set prior to pollution was found. Then the age correspoding to this length on the von Bertal anffy curve was determined. One year was subtracted from this age and its corresponding length ( $L$ 2) on the growth curve was determined. Next the length (L 3) corresponding to an age equal to (age at L 1)-1 was found. The difference between $L_{2} 2$ and $L 3$ represents the extra growth experienced by clams having one year's growth on the pre-pollution growth schedule. This difference was then added to the expected length at year one on the post-pollution curve (von Bertal anffy curve) to obtain the expected length at year one on the pre-pollution curve. The second point on the pre-pollution schedule was found by applying the above procedure to the year class that set two years prior to pollution. This process was repeated for all available 
pre-pollution year classes. An approximation of this technique could be used when few post-pollution points exist by drawing an approximate growth curve by eye. However, it is felt that the variability introduced would reduce the meaningfulness of the results and no such approximations are attempted here.

\section{RESULTS}

For each area the mean length and standard deviation for each age group as obtained from the length-frequency analysis are shown in Table 3. The se data are plotted in Figures 2-7. For West Falmouth, Searsport, and Janvrin Lagoon the calculated von Bertal anffy curve is also plotted. Table 4 describes the parameters for these curves. In addition, pre-pollution growth approximations for Searsport and Janvrin Lagoon are plotted. For the remaining three areas approximate curves have been drawn by eye to smooth out the age-length relationship and to accentuate its change following a pollution event.

The figures demonstrate that changes in the incidence of pollution are reflected by changes in the growth rate. Only west Falmouth fails to show a significant change. The breaks in the curves clearly indicate that pollution has an adverse effect on growth and they reflect the degree to which growth can be reduced. Growth was severly affected at Searsport, Janvrin Lagoon, and Goose Cove. At Goose Cove growth improved following pollution abatement. At west Falmouth the lengths of the year classes existing prior to the spill fail to differ significantly from the lengths expected on the basis of post-spill growth. In would appear that the spill had 
Table 3. The age (yrs.), length ( $\mathrm{mm}$ ), standard devtation, and percent of the sample population for each year class at each site as determined by length-frequency analysis. The sample size for each site is given in parentheses.

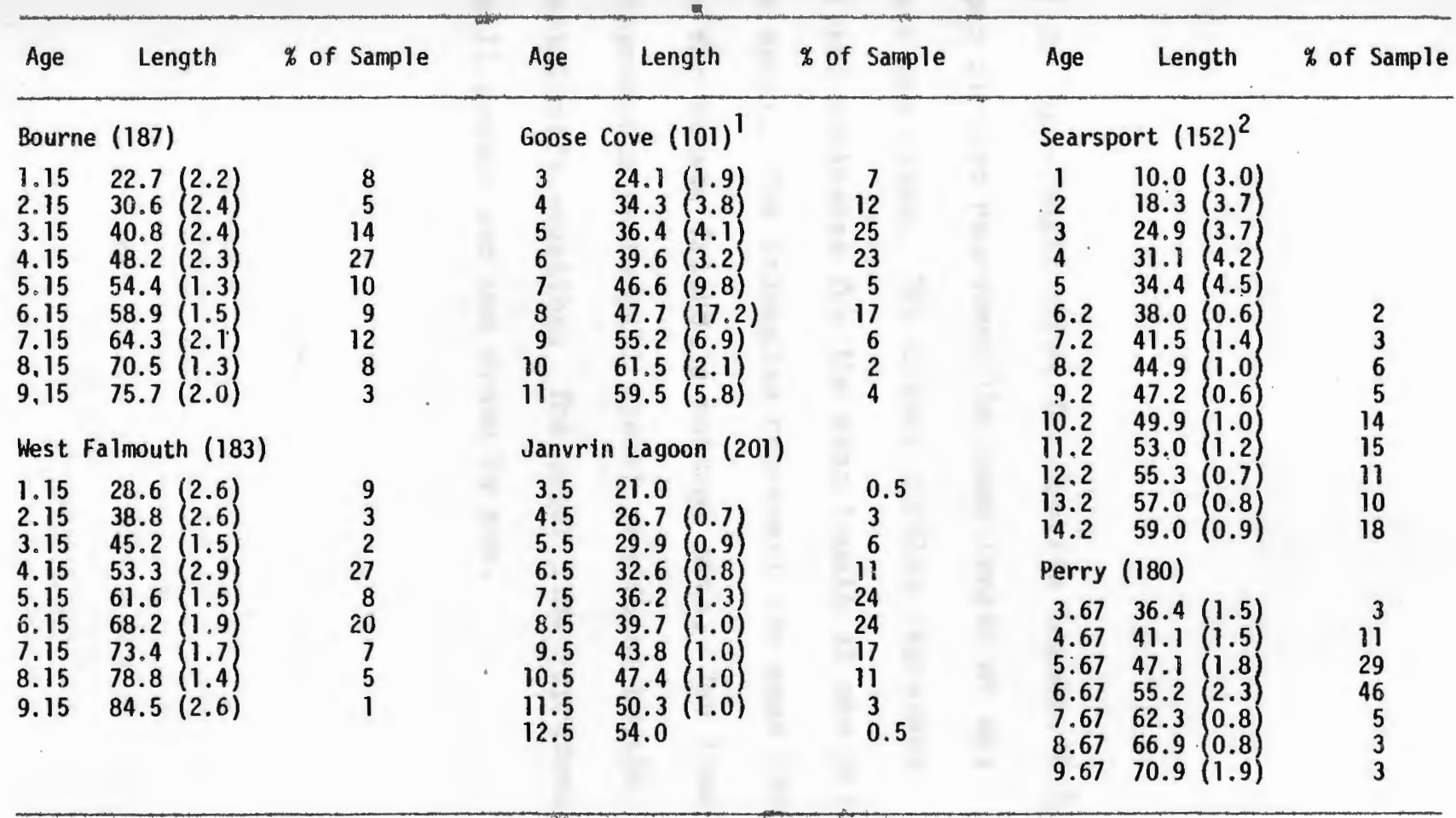

1Ages determined by counting shell rings

First. five year classes from Dow (1978) 
FIGURE 2. Age-length curve for Janvrin Lagoon, N.S. The open circles represent the mean length at age for each age class. The closed circles represent calculated estimates for the mean length at age prior to the spill. The triangles represent the mean length at age for Potato Island, a control site. The lower line represents post-spill growth predicted by the von Bertalanffy equation. The upper 1 ine represents pre-spill growth and was drawn by eye. 


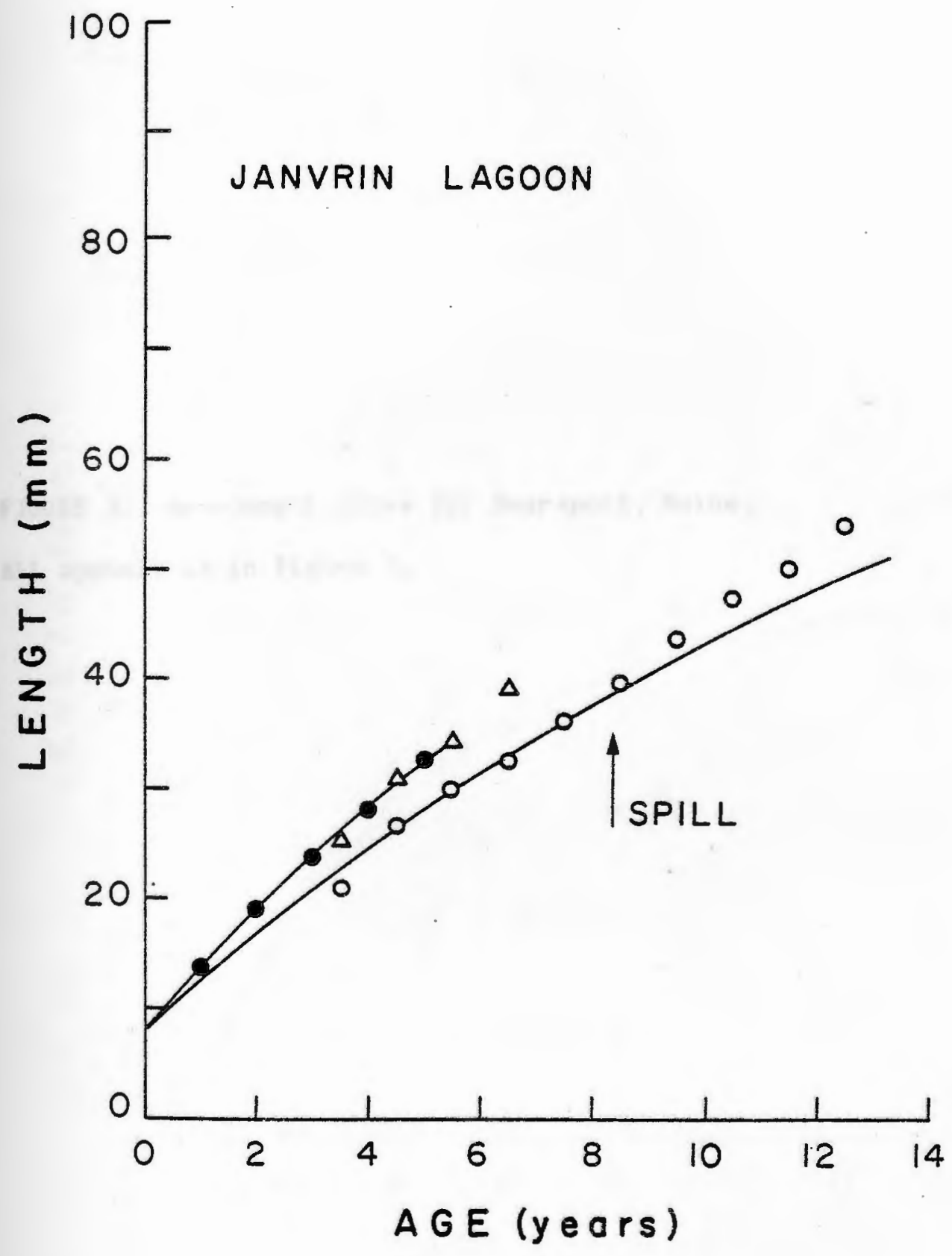


FIGURE 3. Age-leng th curve for Searsport, Maine. All symbols as in Figure 1. 


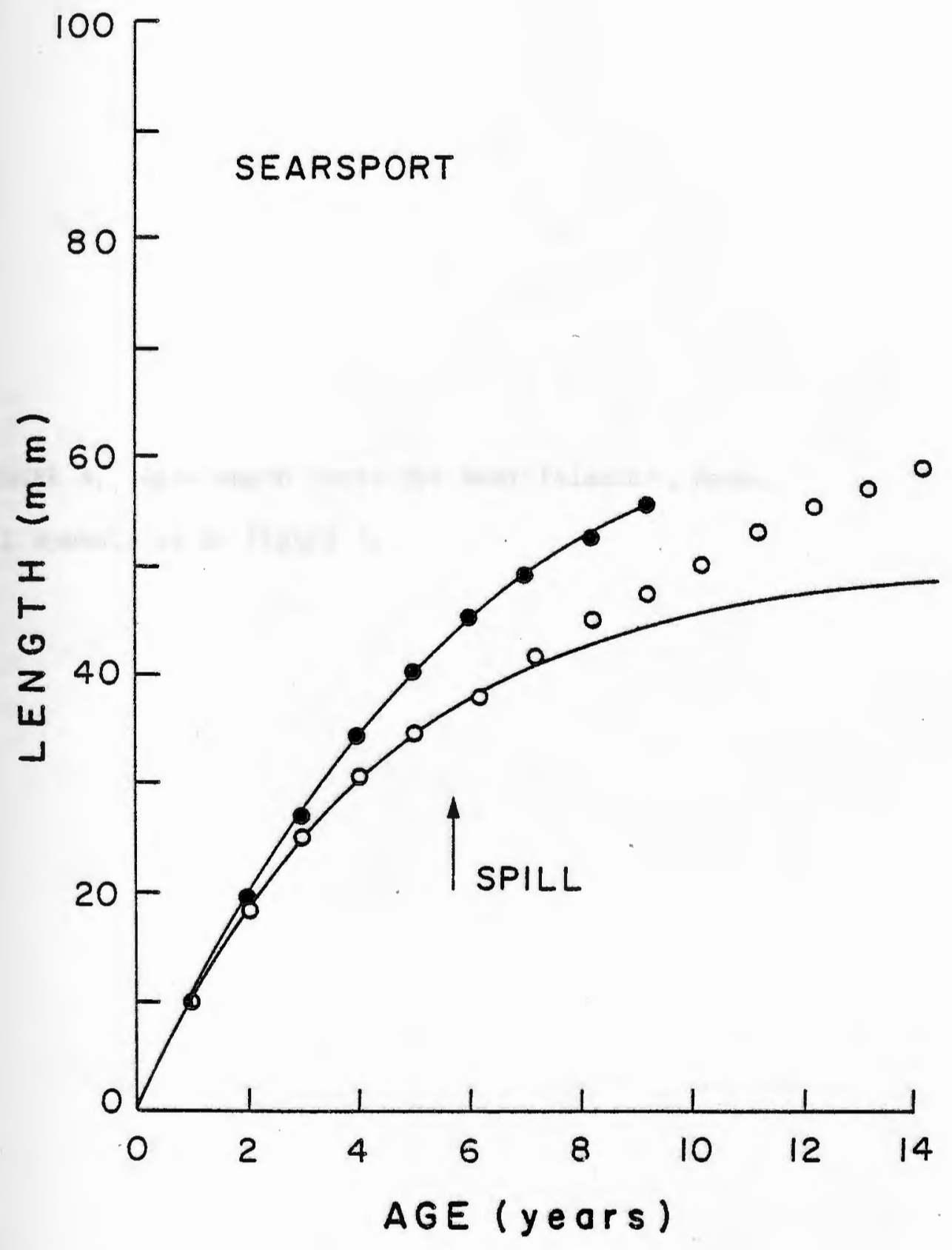


FIGURE 4. Age-leng th curve for West Falmouth, Mass. All symbols as in Figure 1. 


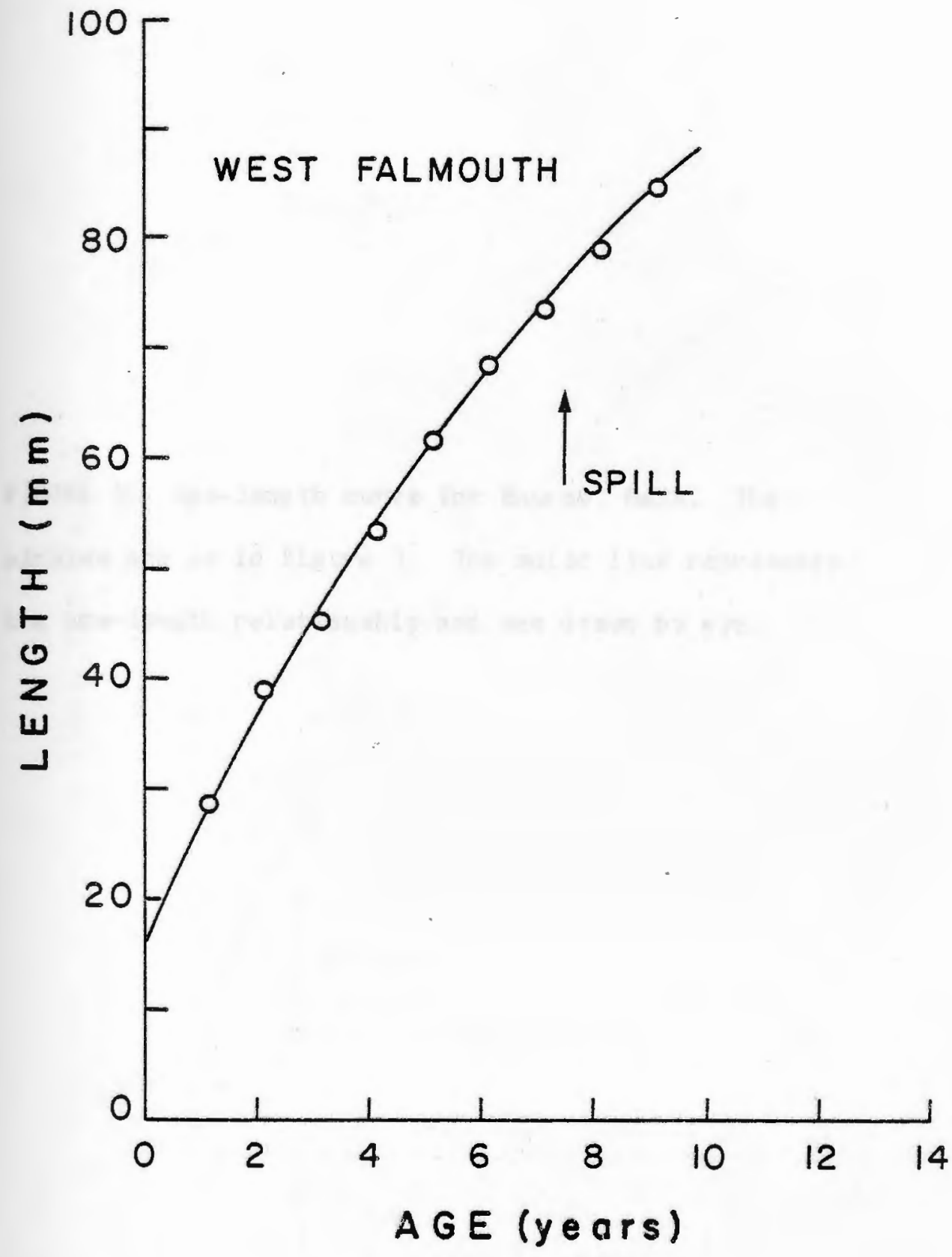


FIGURE 5. Age-leng th curve for Bourne, Mass. The circles are as in Figure 1. The solid line represents the age-length relationship and was drawn by eye. 


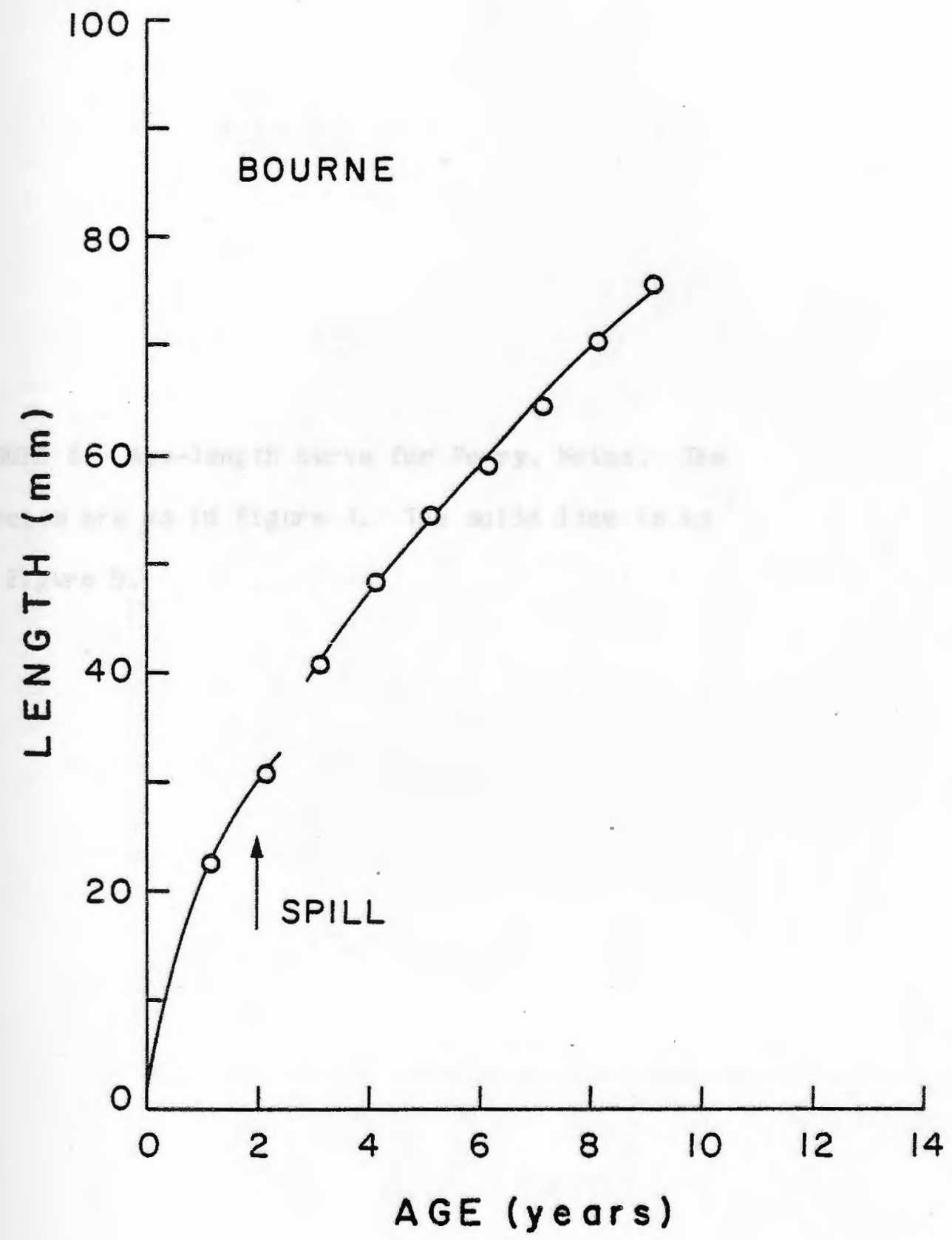


F IGURE 6. Age-leng th curve for Perry, Maine. The circles are as in Figure 1. The solid line is as in Figure 5 . 


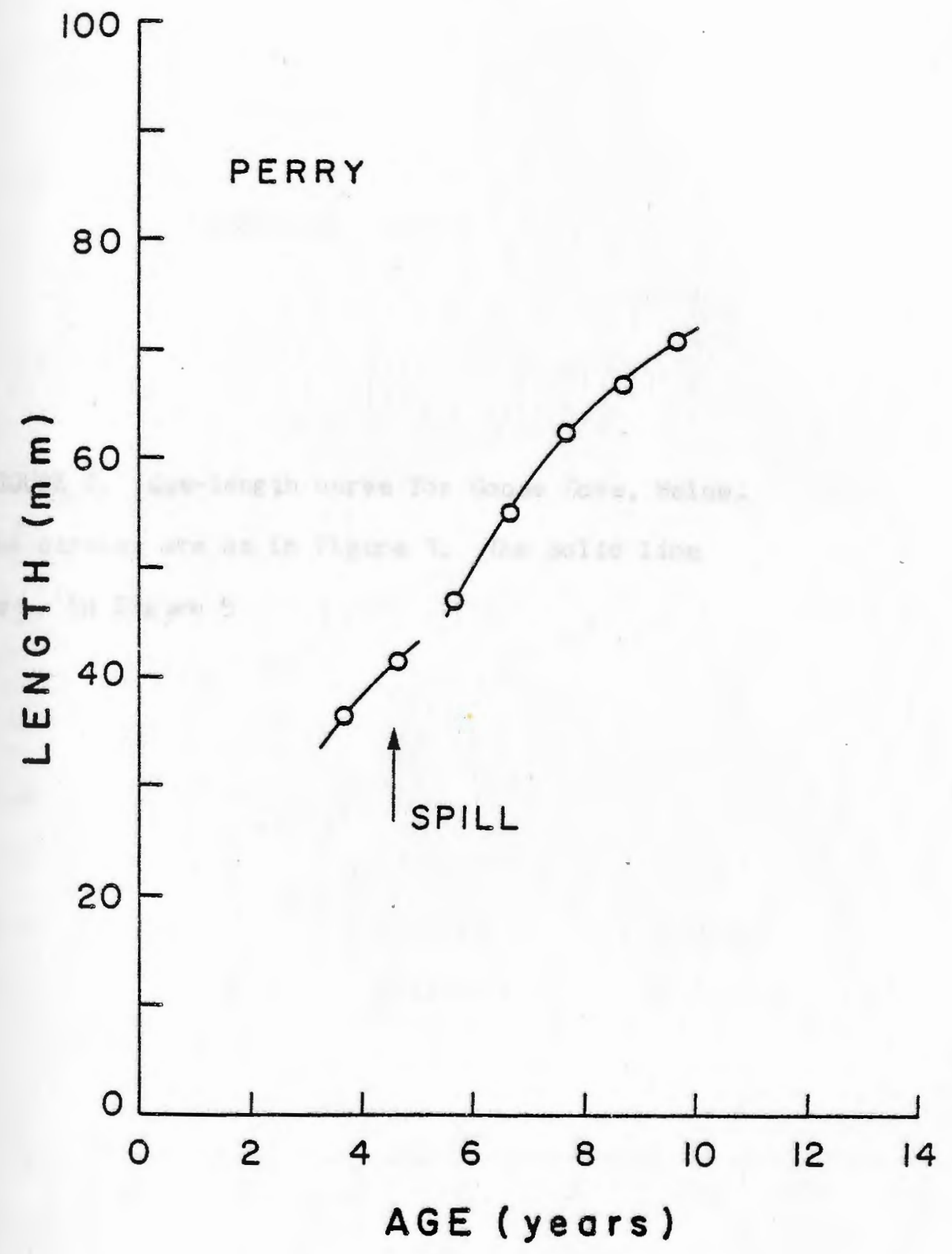


FIGURE 7. Age-length curve for Goose Cove, Maine. The circles are as in Figure 1. The solid line is as in Figure 5. 


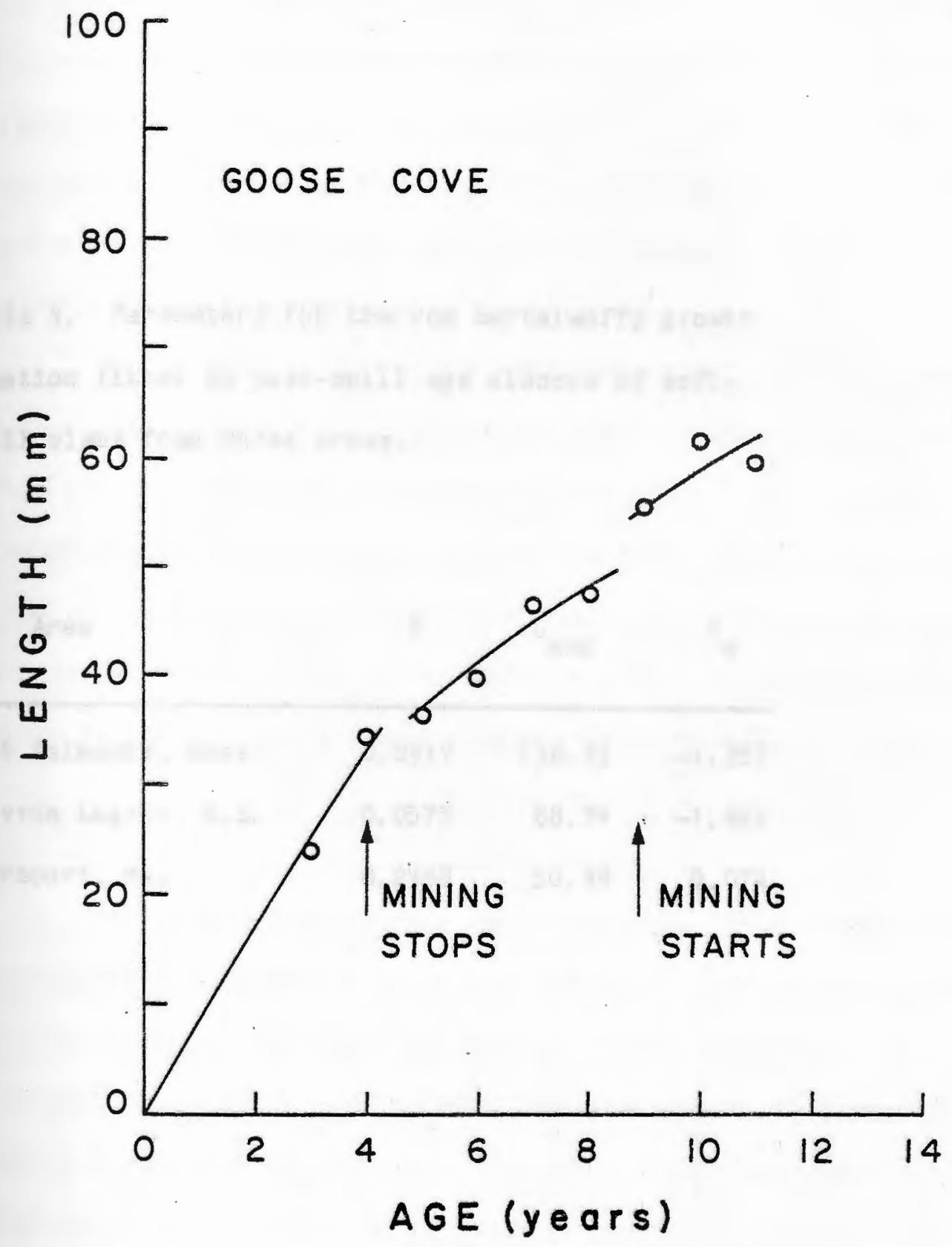


Table 4. Parameters for the von Bertal anffy growth equation fitted to post-spill age classes of softshell clams from three areas.

Area

$\begin{array}{lrrr}\text { West Falmouth, Mass. } & 0.0917 & 136.73 & -1.357 \\ \text { Janvrin Lagoon, N.S. } & 0.0575 & 88.74 & -1.622 \\ \text { Searsport, Me. } & 0.2358 & 50.48 & 0.074\end{array}$


no drastic effect on growth in clams from the collection site.

For comparison purposes the age-leng th determinations for Potato Island (unpublished data) are plotted in Figure 2. This area was used as a control site by Thomas (1978) and by Gilfillan and Vandermeul en (1978) in their studies of Chedabucto Bay. In the latter study it was reported that soft clam growth at Janvrin Lagoon and Potato Island were similar prior to the spill. The estimate of pre-spill growth calcul ated here agrees remarkably well with the age-leng th determinations for Potato Island.

The parameters of the von Bertal anffy curve for Searsport appear anomolous in comparison to the other values shown in Table 4. This probably resul ted from sampling errors (note the standard deviations in Table 3) associated with a small sample size (N=15) and from successive improvments in post-spill growing conditions (see discussion below). The latter would tend to increase the initial slope of the age-leng th curve, thereby increasing $\mathrm{K}$.

\section{DISCUSS ION}

The problems inherently associated with the estimation of population age structure and growth through length-frequency anal ysis were reviewed by Macdonald and Pitcher (1979) and others. A reiteration of these problems does not seem necessary here. It should be pointed out, however, that the growth being measured is that for a cohort of the population and not of individuals (see Ricker, 1975; pp 217-218). The difference between the two arises from the fact that the older modes in the length-frequency histogram are usually composed of slower growing individuals. It has been 
shown for fish that individuals which grow rapidly tend to mature earlier, become senile earlier, and die earlier than slow growing individuals (Gerking, 1957). For M. arenaria in general an inverse relationship has been found between longevity and the rate of growth (Newcombe, 1936), i.e. older clams are slow growers. A good example of this has been shown by Dow (1978) for clams growing at Searsport. As clams grow their burrow depth increases. Faster growing clams were penetrating the buried stratum of oil polluted sediment at an ealier age whereupon mortality occurred. Hence only the slower growing individuals survived and they now constitute the bulk of the older age groups in the population.

The assumption that clams grow according to a fixed schedule (especially after a pollution incident) is probably not valid. For example Dow (1978) has shown successive improvements in the growth of M. arenaria for each year class following the Searsport oil spill. This is due both to the the further weathering of the oil and through the further deposition of clean sediment over the oil contaminated sediment. However, at Searsport and Janvrin Lagoon post-spill recovery has been slow enough to allow the use of the von Bertal anffy curve to generate pre-spill growth estimates. Since only approximate growth estimates have been obtained no effort was made to apply rigorous statistical analysis to the data. It is sufficient here only to illustrate the apparent gross responses of population growth. The results of this study show that there is a response in the growth rate to environmental changes due to pollution. This response is characterized by a noticeable break in the age-length curve. In each case the onset of pollution was coupled with a reduction in 
growth. The exact mechanisms for the observed growth reductions at each site are unknown. The volume of literature on the effects of pollutants on marine organisms in general and on bivalves in particular is now vast but it is still difficult to relate specific effects in the laboratory to responses observed in the field.

For M. arenaria other field studies have shown that the onset of oil pollution is generally followed by a reduction in growth and an increase in mortality. Dow (1975) found a $65 \%$ reduction in the annual growth rate of clams transplanted to a site polluted with Iranian crude oil. At Searsport he reported a reduction in the growth of soft clams following the spill (Dow, 1978). That mortality at Searsport greatly increased when clams came into direct contact with the oil seems to indicate the the oil has either a direct toxic effect or that it 1 eads to smothering (Dow and Hurst, 1975; Dow 1978). Smothering was considered to be the main cause of the large soft clam mortality following the spill of Bunker $\mathrm{C}$ oil at Chedabucto Bay (Thomas, 1973). Gil fillan and Vand ermeulen (1978) found a reduced carbon $\mathrm{flux}$ in soft clams from Janvrin Lagoon as compared to Potato Island. This was coupled with a calculated reduction in the rate of shell growth in Janvrin Lagoon clams following the spill. In an earlier study Gilfillan et al. (1975) found a 50\% reduction in the carbon flux of soft clams polluted by No. 6 fuel oil. They concluded that for bivalves a reduction in the assimilation ratio was a general response to environmental stress which could be triggered by a number of factors including pollution.

For West Falmouth the age-length curve failed to show a break at the time of the spill. There are two possible explanations for 
this. The first explanation is sampling error. Because sampling took place 8 years after the spill it is possible that the age of the sample masked any true effect. Only $6 \%$ of the sample consisted of clams that had set prior to the spill. Such a small sample size could have led to underestimation of the mean lengths for each age class.

The second explanation is that the curve accurately reflects the spill's true effect on growth. While this may be true studies made after the spill indicated initially severe effects. Blumer et al. (1970) reported large mortalities among the benthos, including shellfish, immediately following the spill. Site II was particularly devastated (Sanders, 1978). A hydrocarbon concentration of $69 \mu \mathrm{g} / \mathrm{g}$ (dry wt.) was found in oysters from the tidal creek (Blumer et al., 1970 ) one month after the spill. This value is above those reported for soft clams from other oil impacted sites (Brown et al., 1979). It seems unlikely, then, that clam growth would have remained uneffected. If conditions improved, however, the effect $\mathrm{might}$ become unnoticeable. Sediment oil concentrations at Site II steadily decreased over time reaching $140 \mu \mathrm{g} / \mathrm{g}$ after two years. This is only twice the level reported for indigenous sedimentary hydrocarbons within the area (Blumer and Sass, 1972). The degree of this decrease may be attributable to sediment characteristics at the sampling site. Loose coarse, shifting sand should facilitate rapid depuration or burial of the oil. As a result growth may only have been affected during the first couple of years. Significantly improving conditions invalidate the assumption of a fixed post-spill growth schedule. Hence the von Bertal anffy curve cannot be expected to approximate the 
growth of an affected population. Given the sampling problems mentioned above and the 8 year time 1 age between sampling and the spill any initial effect on growth would now be undetaectable by the methods used. This situation differes both from Bourne and Perry, sites where little oil was found but which were sampled shortly after the spill, and from Searsport and Janvrin Lagoon, sites sampled several years after contamination but which still contained enough oil to adversely affect growth.

The mining operations at Goose Cove could have led to a reduction in growth through three mechanisms: siltation, food destruction, and direct heavy metal toxicity. Dow and Hurst (1972) suggested that much of the damage done by the mining operations was due to heavy siltation and smothering. This would definitely interfere with feeding by clogging the clams' filtering apparatus. They also reported that the mine effluent was highly toxic to phytoplankton, the main food source for soft clams, and that this could contribute to malnutrition and starvation. Eisler (1977) reported that $M$. arenaria was fairly susceptable to heavy metal contamination. Many of the metal concetrations reported by Dow and Hurst (1972) were higher than the lethally toxic concentrations determined in bioasssay studies dealing with pure (Eisler and Hennekey, 1977) and mixed (Eisler, 1977) metal solutions.

The concentrations of metals in soft clams at Goose Cove were still high at the time of sampling, four years after mining operations ceased (L. Fink, personal communication). From the graph in Figure 7 it $c$ an be seen that growth improved following pollution abatement, although it did not seem to have returned to its original 
rate. If starvation and smothering were the major contributing factors to reduced growth then growth should have dramatically improved upon the cessation of $m$ ining activities. This may have been the case. However, the exact degree of recovery is difficult to gauge in this case due to the variability of the data. These observations would lead one to conclude that smothering and starvation were major factors working in conjunction with direct toxicity to reduce growth ouring the period of mining operations. In addition, it appears that to some extent growth was still being adversely affected at the time of sampling possibly due to direct toxic effects.

The pronounced growth reduction at Goose Cove can be attributed to the variety of ways in which the mining effluent affected the clams and to the constant output of effluent during the period of mine operation. Once mining operations ceased recovery was fairly rapid. This is in contrast to recovery at oil polluted sites and reflects the persistence of oil in the sediment, and the different mechanisms by which oil and mining effluent affect clams. Major contributing factors toward reduced growth at Goose Cove such as siltation and food reduction were removed after mining operations ceased. On the other hand, oil itself is a major factor in growth reduction. Oil can be taken up through the siphons (Fong, 1976) and the leaching of oil from saturated sediments following a spill can result in a contaminated water supply for an extended period of time (Mayo et al., 1975). Because oil can be detrimental upon contact (Dow, 1978), the effects of a spill can persist after burial of the oiled sediment. In addition, Vandermeulen (1977) and Vandermeulen 
and Penrose (1978) found that significant quantities (40\%) of oil remained in polluted soft clams following three month exposure to clean water. All these factors contribute to the persistance of an effect following initial hydrocarbon contamination.

In spite of these tendencies, some areas showed signs of recovery. No break in the age-length curve was observed at West Falmouth as discussed earlier. Bourne seems to be a similar case. Little evidence of oil was found at the time of sampling, and the break in the curve (Figure 5) appears like a short depression in an otherwise normal looking growth curve. This would seem to indicate that growth was disrupted only for a short period of time, on the order of a few years.

The techniques used here are considered valuable in assessing pollution effects. Primarily they are useful in detecting gross responses in growth due to changes in environmental quality and they allow one to estimate pre-pollution growth. This is helpful since measurements taken prior to a pollution event are rare and usually fortuitous. A number of studies have used shell growth bands to monitor, in detail, subtle environmental changes (e.g. Kennish and Olsson, 1975). However, these techniques are 1 imited in their application and the methods are involved and costly. The techniques used here sacrifice detail but have more general applicability. For example they allow one to study populations of $\mathrm{M}$. arenaria south of Cape Cod where annual ring formation is unreliable (Mead and Barnes, 1904; Shuster, 1951). The responses observed only directly reflect the effects on growth. They do not directly reflect changes in mortality, settlement, or population age structure. As was observed 
at Searsport, however, continued size-dependent mortality may indirectly affect the resulting growth curve.

\section{ACKNOWLE DGEMENTS}

The author wishes to express his gratitude to those people and agencies who assisted in clam collection, in particular R. L. Dow and M. Richards, Maine Department of Marine Resources; J.M. Hickey, Massachusetts Division of Marine Fisheries; and M.L.H. Thomas, University of New Brunswick. Collection was funded by a grant from the American Petroleum Institute. Saul Saila reviewed the manuscript and provided helpful criticism. 


\section{LITERATURE CITED}

Anderson, J.W. 1977. Responses to sublethal levels of petroleum hydrocarbons: are they sensnsitive indicators and do they correlate with tissue contamination? pp. 95-114. In: D. A. Wolfe (ed.) Fate and Effects of Petroleum Hydrocarbons in Marine Ecosystems and Organisms. Pergamon Press. New York. $478 \mathrm{pp}$.

Barr, A. J., J.H. Goodnight, J.P. Sall, and J.T. Helwig. 1976. A User's Guide to SAS 76. Sparks Press. Raleigh, North Carolina. $329 \mathrm{pp}$.

Belding, D.L. 1930. The soft shelled clam fishery of Massachusetts. Mar. Fish. Ser. Div. Fish Game Mass. 1: $1-65$.

Bl umer, M., and J. Sass. 1972. Oil pollution: persistence of degradation of spilled fuel oil. Science 176: 1120-1122.

Bl umer, M., G. Souza, and J. Sass. 1970. Hydrocarbon pollution of edible shellfish by an oil spill. Mar. Biol. 5: $195-202$.

Brown, R.S., R.E. Wol ke, C.W. Brown, and S.B. Saila. 1979. Hydrocarbon pollution and the prevalence of neoplasia in feral New England soft-shell clams, Mya arenaria. pp. 41-51. In: F.M. Peters (ed.) Animals as Models of Environmental Pollution. National Academy of Science. Washington, D.C.

Cloern, J.E., and F.H. Nichols. 1978. A von Bertal anffy growth model with a seasonally varying coefficient. 
J. Fish. Res. Board Can. 35: 1479-1482.

Dow, R.L. 1975. Reduced growth and survival of clams transplanted to an oil spill site. Mar. Pollut. Bull. 6: $124-125$.

Dow, R.L. 1978. Size-selective mortalities of clams in an oil spill site. Mar. Pollut. Bul1. 9: 45-48.

Dow, R.L., and J.W. Hurst, Jr. 1972. Renewable resource problems of heavy metal mining in coastal Maine. Maine Sea and Shore Fisheries Research Bulletin 35: 1-8.

Dow, R.L., and J.W. Hurst, Jr. 1975. The ecological, chemical, and histopathological evaluation of an oil spill site. Part I. Ecological studies. Mar. Pollut. Bull. 6: $164-166$.

Fisler, R. 1977. Toxicity evaluation of a complex metal mixture to the soft-shell clam. Mar. Biol. 43: 265-276. Eisler, R., and R.J. Hennekey. 1977. Acute toxicities of $\mathrm{Cd}^{2+}, \mathrm{Cr}^{+6}, \mathrm{Hg}^{2+}, \mathrm{Ni}^{2+}$, and $\mathrm{Zn}^{2+}$ to estuarine macrofauna. Arch. Environm. Contam. Toxicol. $6: 315-323$.

Fong, W.C. 1976. Uptake and retention of Kuwait Crude Oil and its effects on oxygen uptake by the soft-shell clam, Mya arenaria. J. Fish. Res. Board Can. 33: $2774-2780$.

Gallueci, V.F., and T.J. Quinn II. 1979. Reparameterizing, fitting, and testing a simple growth model. Trans. Am. Fish. Soc. 108: $14-25$. Gerking, S.D. 1957. Evidence of aging in natural populations of fishes. Gerontologia 1: 287-305. 
Gilfillan, E.S., S.A. Hanson, D.J. Page, D. Mayo, J. Cooly,

J. Chalfant, T.Archambeault, A. West, and

J.C. Har shbarger. 1977. Comprehensive study of petroleum hydrocarbons in the marine environment at Long Cove, Searsport, Maine. Final Report to the Dept. of

Environmental Protection, Contract №. 906439. 192 pp. Gilfillan, E.S., D. Mayo, S. Hanson, D. Donovan, and L.C. Jiang. 1976. Reduction in carbon flux in Mya arenaria caused by a spill of No. 6 fuel oil. Mar. Biol. 37: 115-123.

Gilfillan, E.S., and J.H. Vandermeulen. 1978. Alterations in growth and physiology of soft shell clams, Mya arenaria, chronically oiled with Bunker C from Chedabucto Bay, Nova Scotia, 1970-76. J. Fish. Res. Board Can. 35: 630-636. Hampson, G.R., and E.T. Moul. 1977. Salt marsh grasses and \#2 fuel oil. Oceanus 20(4): 25-30.

Hyl and, J.L., and E.D. Schneider. 1976. Petroleum hydrocarbons and their effects in marine organisms, populations, communities, and ecosystems. pp. 436-506. In: Sources, Effects and Sinks of Hydrocarbons in the Aquatic Environment. Proceedings of a conferance held 9-11 August, 1976. American Institute for Biological Sciences. Washington, D.C.

Kennish, M.J., and R.K. Ollson. 1975. Effects of thermal discharges on the microstructural growth of Mercenaria mercenaria. Environ. Geol. 1: $41-64$.

Macdonald, P.D.M., and T.J. Pitcher. 1979. Age-groups from size-frequency data: a versitle and efficient method of 
analyzing distribution mixtures. J. Fish. Res. Board Can. 36: $987--1001$.

Ma yo, D.W., C.G. Cogger, D.J. Donovan, R.A. Gambardella, L.C. Jiang, and J. Quan. 1975. The ecological, chemical, and histopathological evaluation of an oil spill site. Part II. Chemical studies. Mar. Pollut. Bull. 6: $166-171$.

Mead, A.D., and E.W. Barnes. 1904. Observations on the soft-shell clam (fifth paper). R.I. Comm. Inl and Fish., 34th. Annu. Rep., pp. 29-68.

Newcombe, C.I. 1936. A comparitive study of the abundance and the rate of growth of Mya arenaria L. in the Gulf of St. Lawrence and Bay of Fundy regions. Ecology 17: $418-428$.

Ricker, W.E. 1975. Computation and interpretation of biological statistics of fish populations. Bull. Fish. Res. Board Can. 191: 1,-382.

Rosenberg, R. 1976. Benthic faunal dymamics during succession following pollution abatement in a Sweedish estuary. Oikos 27: $414-427$.

Sanders, H.L. 1977. The West Falmouth oil spill-Florida, 1969. Oceanus 20(4): 15-24.

Sanders, H.L. 1978. Florida oil spill impact on the Buzzards Bay benthic fauna: West Falmouth. J. Fish. Res. Board Can. 35: $717-730$

Shuster, C.N., Jr. 1951. On the formation of midseason checks in the shell of Mya. Anat. Rec. 111: 543. 
Tesch, F.W. 1971. Age and growth. pp. 98-130. In: W.E. Ricker (ed.) Methods for Assessment of Fish

Production in Fresh Waters. Int. Biol. Program, Handboook

3. Blackwell Seientific Publications, Ox ford.

Thomas, M.L.H. 1973. Effects of Bunker $\mathrm{C}$ oil on intertidal and lag oonal biota in Chedabucto Bay, Nova Scotia.

J. Fish. Res. Board Can.30: 83-90.

Thomas, M.L.H. 1978. Comparison of oiled and unoiled intertidal communities in Chedabucto Bay, Nova Scotia. J. Fish. Res. Board Can. 35: 707-716.

Vand erborst, J.R., J.W. And erson, P. Wilkinson, and D.L. Woodruff. 1978. Estimation of effects from oil on intertidal populations: experimental perturbations versus natural variation. pp. 807-820. In: Procedings of the Conferance on Assesment of Ecological Impacts of Oil Spills, 14-17 June 1978. American Institute for Biological Sciences. Washington, D.C.

Vandermeulen, J.H. 1977. The Chedabucto Bay spill - Arrow, 1970. Oceanus 20(4): $31-39$.

Vandermeul en, J.H., and W. R. Penrose. 1978. Absence of aryl hydrocarbon hydroxylase (AHH) activity in three marine bivalves. J. Fish. Res. Board Can. 35: 643-647. 
ADAPTATIONS TO ENVIRONMENTAL VARIATION AND THE LIFE-HISTORY STRATEGY OF THE SOF T $\rightarrow$ SHELL CLAM, Mya arenaria:

Relationships Between Parameters

Rickard S. Appeldoorn

Graduate School of Oceanography

University of Rhode Isl and

Kingston, Rhode Isl and 02881 
SUMMAR Y

Rel ationships between various 1 ife-history parameters were studied in 25 populations of the soft-shell clam, Mya arenaria, in order to elucidate the species's modes of adaptation and life-ristory strategy. The relationships between growth and the other parameters were analyzed within the context of latitudinal variations in the environment. An association was found between decreasing latitude and the following traits: faster growth, greater variations in juvenile mortality, larger size of maturation, larger egg size, lower egg density, and decreasing longevity. With the exception of longevity, these relationships and those evident in the literature are consistant with the predictions of a bet-hedging life-history strategy. Decreasing longevity can be explained by the increase in stress on $M$. arenaria, a boreal species, toward the southern portions of its geographical range. In terms of life-history evolution high and variable density independent juvenile mortality is seen to be a more significant factor than a trend in adult mortality.

Pair-wise comparisons between populations on a local scale showed a relationship between larger egg size and greater egg density. This trend seems to be associated with the condition of the population and represents a physiological response to local conditions within the framework imposed by genetic adaptations to latitudinal variations in the environment.

The proportion of females (52\%) was found to be significantly greater than the proportion of males. No evidence of a mechanism behind this disparity was detected, and its cause remains enigmatic. 
INTRODUCTION

The theory of I ife-history strategies has developed rapidly over the last 15 years. A life-history strategy is a design for survival. It consists of a set of traits coadapted through natural selection, which provide a species with a means of dealing successfully with environmental problems. In other words, a strategy is the way a species genetically adapts to variations in its environment. Stearns (1976) provided an excellent review of the history and development of the study of life-history tactics. He emphasized the need for more empirical work and suggested that this work be done through the study of intraspecific populations in contrasting environments.

A major factor limiting the number of empirical studies is the difficulty in measuring the necessary population parameters, especially those involving reproduction. As a consequence, only a few studies have been conducted on benthic invertebrates and these have primarily dealt with brooding species. This work is exemplified by an excellent study on the freshwater mussel Anodonta piscinalis by Haukioja and Hakal a (1979). Much less work bas been done on broadcast spawners. Age-fecundity relationships have been reported for the mussel Mytilus edulis (Thompson, 1979; Bayne, 1976) and for the soft-shell clam Mya arenaria (Brouseau, 1978b). Further work on the fecundity and mortality schedules of Mya arenaria has been attempted (Brouseau, 1978a).

Mya arenaria is a suitable species for the study of Iife-ristory strategies. It is abundant and occupies a variety of habitats over a wide geographic range. Thus Mya encounters a wide 
range of conditions, and thereby satisfies Stearns's (1976) criterion of contrasting environments. Being a deep burrowing infaunal filter feeder, Mya is exposed to both the conditions of the substrate and the overlying water column. Being sedentary it cannot escape any prolonged deleterious environmental perturbations; to survive it must be able to cope with these problems. Lastly, M. arenaria is commercially important (MacKenzie, 1979) and further und er standing of the species may prove useful to its management.

The purpose of this study is to establish relationships between various life-history parameters in Mya arenaria and to use those relationships to elucidate its life-history strategy. The parameters are estimated from data collected on 25 populations of Mya arenaria. These populations were initially sampled for a study on neoplasia and pollution (Brown et al., 1979). As such, the sampling design and the data obtained were not entirely suited for the present study. Samples were collected at different times and under different conditions. Many of the estimates made here are crude approximations and estimates could not be made on all parameters for all populations. This variability makes individual comparisons tenuous. However overall trends can be educed. It has been shown that a considerable and consistant change in environmental parameters (temperature, tidal position, sediment grain-si ze distribution) exists with changing latitude (Appeldoorn, 1980). This study deals mainly with the response of Mya arenaria to this latitudinal gradient in its environment. 
MATERIALS AND METHODS

Data collection

Samples of soft-shell clams were collected at 25 sites along the northeast coast of North America (Table 1 and Figure 1). All individuals were measured for shell length, weighed, and sectioned for histological analysis. The sections were prepared using standard histological techniques (Brown et al.. 1977), cut at $6 \mathrm{~m}$, and stained with hematoxyl in and eosin. These data were then analyzed to obtain estimates of some population life-history parameters.

Calculation of the Variation in Juvenile Mortality (VJM)

To adequately discuss variations in population parameters it is necessary to have some estimate of the stability of the various environments. Environmental stability can be inferred by a low variability in reproductive success or juvenile mortality (Stearns, 1976). To estimate the variation in juvenile mortality an adation of catch-curve analysis (Ricker, 1975) was employed. Under the assumption of constant adult mortality and nonselective sampling there is a linear relationship between age and the natural logarithm of age-class size. Data from Brouseau (1979a) indicate that adult mortality in M. arenaria is uniformly low amoung the age classes studied. In the present analysis only the larger year classes (usually $>40 \mathrm{~mm}$ ) were used to ensure complete recruitment. Under these two assumptions any variation around the linear relationship must represent variability in the set and survival of juveniles (Haukioja and Hakala, 1978). In a regression of $\log _{e}(N)$ on age the standard deviation of the residuals is then a measure of the 
Table 1. Life-history parameters estimated for each population. Measurements of egg density and egg diameter represent late developing individuals. -: Missing value VJM: Variation in juvenile mortality DSI: Disease severity index

\begin{tabular}{|c|c|c|c|c|c|c|c|c|c|c|}
\hline $\begin{array}{l}\text { Samp11ng } \\
\text { S1 te }\end{array}$ & $\begin{array}{l}\text { Site } \\
\text { Code }\end{array}$ & $\begin{array}{l}\text { Date of } \\
\text { Sampling }\end{array}$ & $\omega$ & V.JM & $\begin{array}{l}\text { Longevity } \\
\text { (years) }\end{array}$ & $\begin{array}{l}\text { Size of } \\
\text { Maturation } \\
\text { (InI) }\end{array}$ & $\begin{array}{l}\text { Egg } \\
\text { Density }\end{array}$ & $\begin{array}{l}\text { Egg } \\
\text { Dlameter } \\
\text { ( } \mu \mathrm{m})\end{array}$ & DSI & $\begin{array}{l}\text { Proportion } \\
\text { of Females } \\
(\%)^{a}\end{array}$ \\
\hline Tangler Sound MD & TS & $27-3-78$ & 29.108 & -.226 & 4.39 & - & 676 & 44.9 & 6.359 & $49.7(167)$ \\
\hline B1g Annemessex River MD & AR & $27-3-78$ & 29.354 & .301 & 4.84 & -- & 495 & 36.6 & 2.801 & $57.8(166)$ \\
\hline Navesink River N.J & NR & $2-6-77$ & 24.034 & .212 & 15.03 & 27 & - & - & 2.155 & $48.9(180)$ \\
\hline Rarttan Bay NJ & RB & $1-6-77$ & 14.034 & -.014 & 4.11 & 24 & - & - & 0.405 & $50.0(194)$ \\
\hline W1nnapaug Pond RI & WP & $18-7-77$ & 21.996 & .050 & 1.3 .13 & 20 & - & - & 6.545 & $55.3(170)$ \\
\hline Quonochontaug Pond-1 RI & $\mathrm{Q1}$ & $22-6-76$ & .10 .954 & -.101 & 9.37 & 29 & 1515 & 38.9 & - & $56.7(60)$ \\
\hline Quonochontaug Pond-2 KI & Q2 & $4-4-77$ & 1.1 .866 & -.510 & 12.02 & 28 & - & - & 5.074 & 49.1 (159) \\
\hline Saugatucket RIver RI & SR & $14-12-78$ & 15.329 & - & 14.07 & 32 & - & - & - & $54.2(144)$ \\
\hline W1 ckford RI & WK & $15-3-76$ & 20.258 & .273 & 8.34 & - & 1009 & 42.2 & - & $54.7(190)$ \\
\hline Coonamessett River MA & $\mathrm{CR}$ & $12-5-77$ & 19.521 & .220 & 14.15 & - & - & - & 6.581 & 51.1 (133) \\
\hline Allen Harbor RI & AH & $27-9-77^{b}$ & 10.222 & -.352 & 12.25 & 19 & 1303 & 38.5 & 9.863 & $53.3(283)$ \\
\hline West Falmouth MA & WF & $3-5-77$ & 12.538 & - & 9.67 & 21 & - & - & 6.914 & $52.7(186)$ \\
\hline New Bedford MA & NB & $18-10-78$ & 13.678 & -.009 & 8.10 & - & - & - & 9.756 & $48.1(156)$ \\
\hline East Greenwich Cove RI & EG & $3-3-76^{b}$ & 12.662 & .051 & 7.10 & 17 & 890 & 38.4 & - & $51.6(310)$ \\
\hline Bourne MA & $\mathrm{BN}$ & $22-5-76$ & $8.500^{\mathrm{c}}$ & - & - & 30 & 1285 & 40.4 & - & $50,3(159)$ \\
\hline Watchemoket Cove RI & WC & $12-5-76$ & 12.301 & .484 & 7.54 & 23 & - & - & - & $64.6 \quad(82)$ \\
\hline Portiand ME & P'T & $21-7-76$ & 9.696 & -.113 & 14.73 & 27 & 1318 & 25.9 & - & $54.3(162)$ \\
\hline Deer Isle ME & DI & $22-9-76^{b}$ & 8.533 & -.285 & - & 32 & 1541 & 35.9 & 4.512 & $50.3(159)$ \\
\hline Goose Cove ME & GC & $20-7-76$ & $8.500^{\mathrm{c}}$ & - & - & 25 & 1414 & 35.1 & - & $52.2(161)$ \\
\hline Long Cove, Searsport ME & $S P$ & $22-9-76^{b}$ & $11.903^{\mathrm{c}}$ & - & - & 30 & 1260 & 35.1 & 10.289 & $52.7(693)$ \\
\hline Stockton llarbor ME & SH & $13-9-78$ & 7.668 & -.228 & 13.26 & 25 & - & - & 11.267 & $48.1(156)$ \\
\hline Perry ME & PY & $15-8-78$ & - & - & - & 41 & - & - & 0.539 & $46.7(167)$ \\
\hline Robinston $M E$ & RS & $15-8-78$ & 11.869 & .278 & 10.85 & 36 & - & - & 4.497 & $50.3(185)$ \\
\hline Janurin Lagoon NS & JL & $18-7-78$ & $5.103^{\mathrm{c}}$ & - & - & 27 & - & - & 4.976 & $51.9(183)$ \\
\hline Potato Island NS & PI & $18-7-78$ & 8.041 & -.031 & 9.79 & 28 & 1337 & 37.6 & 2.223 & $53.5(198)$ \\
\hline
\end{tabular}

a Total number of sexed tadividuals is glven in parentheses

b supplementary samples were taken on other dates

c Previously unreported estimate 
FIGURE 1. Location of sampling sites. 


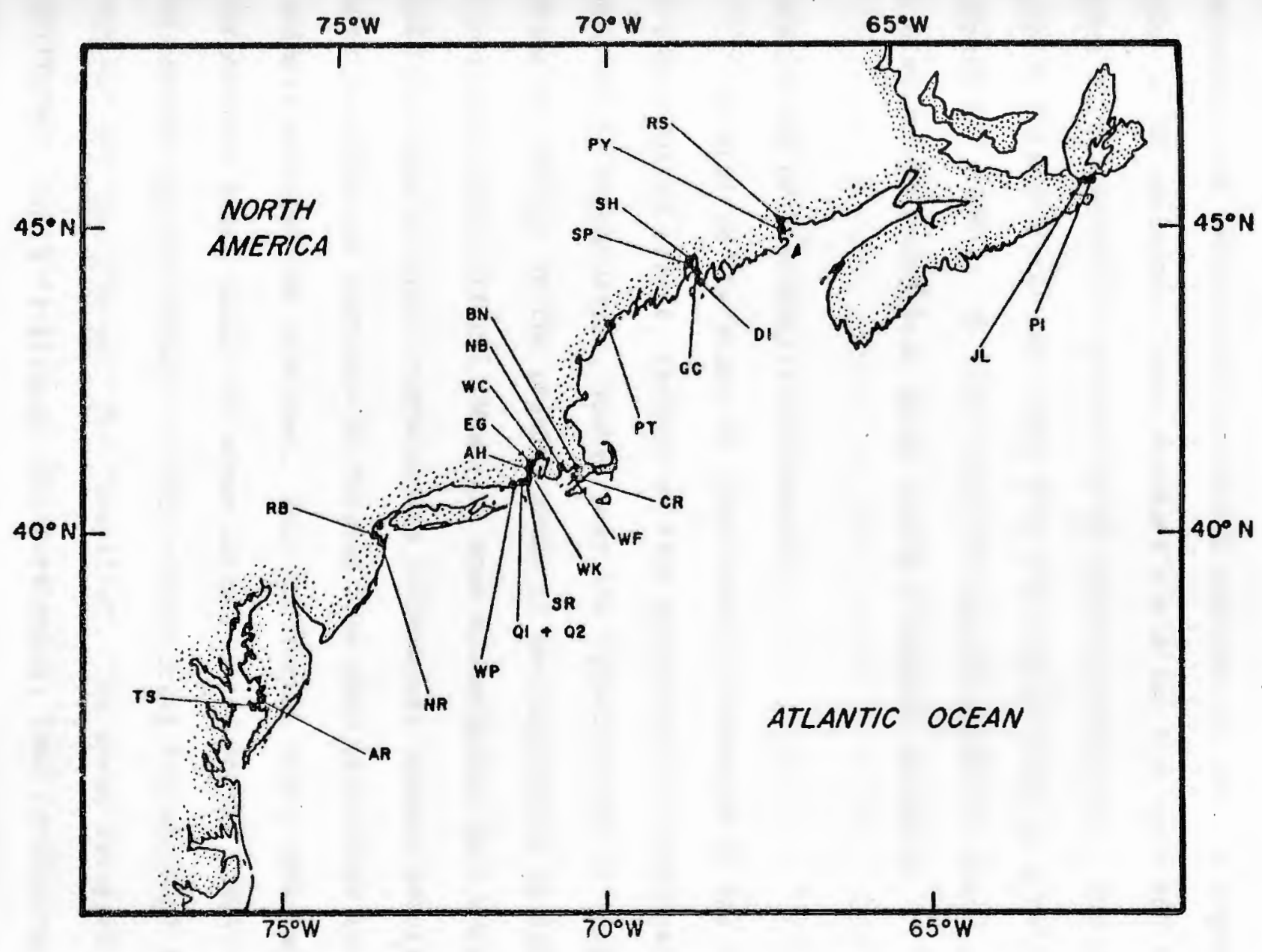


variation about the line. Since the standaro deviation is somewhat dependent upon sample size a regression of the standard deviation against the number of age groups was made. The residuals from this regression are taken as the corrected estimate of VJM. A negative value would indicate a lower standard deviation than expected and hence a low degree of variability in juvenile mortality. The data used in this analysis was taken from a previous study on growth (Appeldoorn, 1980). In that study the age structure of each population was determined using length frequency analysis.

Calculation of Reproductive Parameters

Central to the study of life-history strategies is the concept of reproductive effort, defined as "the proportion of resources diverted to reproduction, summed over the time interval in question" (Stearns, 1976). In the present study it was impossible to estimate true reproductive effort. However, some measurements were made that could indicate relative reproductive differences between populations. Using histological sections 20 females from each population were randomly selected and examed. Each individual was classified as to reproductive stage using the seven catagories of Porter (1974) and the terminology of Brouseau (1978b) substituting "developing" for "active" and "indifferent" for "inactive". The seven catagories are: ind ifferent, early developing, mid-developing, late developing, ripe, partially spawned, and spent. As with previous studies (Ropes and Stickney, 1965; Porter, 1974; Brousseau, 1978b) the continuous nature of gametogenic activity often led to classification problems. Frequently clams at the spent stage contained new ova already 
developing for a possible second spawn.

Egg diameters were measured on five ova per individual using an occular micrometer. These data were converted to the average egg size at each observed reproductive stage.

Triplicate egg density counts were made for each individual. Egg density was defined as the number of eggs (with nucleus visible)/microscope field $=.29 \mathrm{~mm}^{2}$. Although based on a single section, these measurements were assumed to be reliable since Brousseau (1978b) found that egg densities remained constant throug hout the gonad. These data were converted to the average egg density at each observed reproductive stage. The density estimates reflect the fecundity/unit of gonadal tissue, termed relative fecundity. Absolute fecundity could not be measured because variations in the relative gonadal volume could not be accounted for if indeed such variations took place.

Other Parameters

Sex proportions were calculated for each population by comparing the number of females to the total number of sexed individuals. All sex determinations were based on histological examination of the gonads.

Growth rate estimates were taken as the parameter w (Gallucci and Quinn, 1979) of the von Bertal anffy growth model. These estimates were obtained from a previous detailed analysis of growth in these populations (Appeldoorn, 1980).

Longevity was crudely estimated by calculating the age of the 1 argest individual collected at each site. 
The size of sexual maturation was estimated as the size of the smallest female collected at each site. Size was measured instead of age because sexual maturation occurs when a clam reaches a certain size rather than a certain age (Belding, 1930; Coe and Turner, 1938; Hanks, 1963). In addition, the concept of increased cost of early maturation is easier to comprehend from the standpoint of size, especially given the wide variations in growth that occur between $M$. arenaria populations.

For some sites estimates for the pathological condition of the clam population were available. These were taken as the disease severity index (DSI) of Walker et al. (in press).

\section{Calculation of Regressions}

Geometric mean functional regressions were used in all cases due to the natural variability of both the $x$ - and $y$-variates, and the small sample size (Ricker, 1973). In the regressions between population parameters no single parameter could be considered as the independent variable. As a standard, the growth parameter $\omega$ was somewhat arbitrarily chosen as the $x$-variate in these regressions. The rest of the parameters were then regressed against $\omega$. All regressions were run using the GLM procedure of SAS79 (Helwig and Council, 1979). The predictive regression coefficient (slope) b was converted to the functional regression coefficient $v$ throug $\mathrm{v}=\mathrm{b} / \mathrm{r}$ where $r$ is the correlation coefficient. The significance of the regression can be tested by seeing if the $95 \%$ convidence interval around v ( $v \pm 2$ standard errors) brackets zero (Ricker, 1973). 
RESULTS

Estimates of all the parameters used in the regressions are shown in Table 1.

\section{Sex Proportions}

From Table 1 it $c$ an be seen that in the majority of the populations females outnumbered males. The overall average proportion of females was $52.3 \%$. The null hypothesis of equal sex ratios among all samples was tested using the Wilcoxon sign rank test (Hollander and Wolfe, 1973). The test showed that females significantly outnumbered $\mathrm{males}\left(\mathrm{T}^{*}=2.874, \mathrm{p}=.004\right)$ so the null hypothesis was rejected.

VJM, Longevity, Maturation vs $\omega$

Table 2 shows the results of the regression of VJM, long evity, and the size of maturation against growth. The regressions indicated that longevity was negatively related to growth while the size of maturation and variation in juvenile mortality were positively associated with growth. The size of maturation showed the weakest correlation. This might be expected since the realized size of maturation depends upon the present nutritional condition of the population (Coe and Turner, 1938). The genetically determined minimum size of maturation would be realized only if the nutritional requirements were met.

Egg Diameter and Egg Density vs $w$

Table 2 al so shows the results for the regressions of egg 
Table 2. Results of the functional regressions. The slope of the predictive regression (b) can be found by $b=v \cdot r$

\begin{tabular}{lcccc}
\hline Regression & $r$ & Intercept & $\mathrm{v}=$ slope & $\begin{array}{l}\text { Approximate 95\% } \\
\text { Confidence Limits }\end{array}$ \\
\hline VJM vs $\omega$ & .372 & -0.575 & 0.038 & $0.020<\mathrm{v}<0.055$ \\
Longevity vs $\omega$ & .278 & 18.473 & -0.536 & $-0.785<\mathrm{v}<-0.287$ \\
Maturation Size vs $\omega$ & .190 & 36.557 & -0.861 & $-1.361<\mathrm{v}<-0.360$ \\
Egg Size vs $\omega$ & .437 & 29.137 & 0.594 & $0.256<\mathrm{v}<0.932$ \\
Egg Density vs $\omega$ & .903 & 1762.743 & -42.320 & $-53.819<\mathrm{v}<-30.820$ \\
\hline
\end{tabular}


diameter and egg density against growth. These analyses were based soley on individuals classified as being in the late developing stage of reproduction. This stage was chosen because more populations had individuals in this stage than in any other. The data in Table 1 gives the average values for the late developing stage individuals. The regressions show a positive relationship between egg size and growth, and a strong negative relationship between egg density and growth.

Egg Diameter vs Egg Density

Table 3 illustrates the relationship between egg diameter and egg density in a series of pair-wise comparisons. The sample pairs consist of two sites sampled proximally in both time and space. Hence any apparant trends should represent differences due to variations in local conditions. The table shows evidence of a positive relationship between egg diameter and egg density. This relationship was tested using a binomial test ( $\mathrm{Holl}$ ander and Wolfe, 1973), and was found to be significant at $p=0.07$. At only 2 of the 7 sites for which comparisons of the pathological condition could be made did a poorer condition associate with a larger egg density and diameter. This relationship was similarly tested and found to become significant at pan 0.22 .

DISCUSSION

Sex Proportions

In previous studies on Mya arenaria Shaw (1965), Pfitzenmeyer (1972), Porter (1974), and Brousseau (1978b) all reported that the 
Table 3. Pair-wise comparisons of egg density, egg diameter, and DSI. -: Missing value

\begin{tabular}{llll}
\hline Comparison & $\begin{array}{l}\text { Larger Egg } \\
\text { Density }\end{array}$ & $\begin{array}{l}\text { Larger Egg } \\
\text { Diameter }\end{array}$ & $\begin{array}{l}\text { Smaller } \\
\text { DSI }\end{array}$ \\
\hline GC - PT & GC $^{\mathrm{a}}$ & $\mathrm{GC}$ & - \\
$\mathrm{JL}-\mathrm{PI}$ & $\mathrm{JL}^{\mathrm{b}}$ & $\mathrm{JL}$ & $\mathrm{PI}$ \\
$\mathrm{PY}-\mathrm{RS}$ & $\mathrm{RS}^{\mathrm{C}}$ & $\mathrm{PY}$ & $\mathrm{RS}$ \\
$\mathrm{EG}-\mathrm{WK}$ & $\mathrm{WK}^{\mathrm{a}}$ & $\mathrm{WK}$ & - \\
$\mathrm{EG}-\mathrm{BN}$ & $\mathrm{BN}^{\mathrm{b}}$ & $\mathrm{EG}$ & - \\
$\mathrm{EG}-\mathrm{WC}$ & $\mathrm{WC}^{\mathrm{b}}$ & $\mathrm{EG}$ & - \\
$\mathrm{BN}-\mathrm{WC}$ & $\mathrm{BN}^{\mathrm{b}}$ & $\mathrm{BN}$ & - \\
$\mathrm{AR}-\mathrm{TS}$ & $\mathrm{TS}^{\mathrm{a}}$ & $\mathrm{TS}$ & $\mathrm{AR}$ \\
$\mathrm{AH}-\mathrm{Q} 2$ & $\mathrm{Q}^{\mathrm{a}}$ & $\mathrm{Q} 2$ & $\mathrm{Q} 2$ \\
$\mathrm{DI}-\mathrm{SP}$ & $\mathrm{DI}^{\mathrm{a}}$ & $\mathrm{DI}$ & $\mathrm{DI}$ \\
$\mathrm{DI}-\mathrm{SH}$ & $\mathrm{DI}^{\mathrm{c}}$ & $\mathrm{DI}$ & $\mathrm{DI}$ \\
$\mathrm{SP}-\mathrm{SH}$ & $\mathrm{SP}^{\mathrm{C}}$ & $\mathrm{SP}$ & $\mathrm{SP}$
\end{tabular}

a Comparisons involving reproduction were made using late developing individuals

b Comparisons involving reproduction were made using ripe individuals

c Comparisons involving reproduction were made using early developing individuals 
porportion of females did not significantly differ from the proportion of males. Porter's study was the only one to give the actual figures. He found slightly more females (52\%). The present finding of an unequal sex ratio is not unexpected, though. Unequal sex ratios are not uncommon in the mollusks, including the bivlaves and Fretter and Graham (1964) stated the females tend to out number males in gonochoristic species. Some examples of the percentage of females found in some bivalves are: Cardium (-Cerastoderma) edule $40 \%$ Donax vittatus $45 \%$; Tellina balthica $53 \% ;$ T. fragilis $52 \%$; Scrobicularia piperata 59\%; Pholas candida 55\%; and Anodonta cygnea 46\% (Pel seneer, 1926). Normally in the se species the disparity is not present in the young but increases with age. It is assumed to be due to a higher mortality rate for the males (Pel seneer, 1926). In the present study, populations with similar growth rates were pooled, and trends in the sex ratio were examined. No trend with size was apparent. The cause for this disparity remains enigmatic.

\section{Life-History Strategy}

Previous empirical and theoretical studies have identified two opposing life-history strategies: $r$ - and $\mathrm{K}-$ selection, and bet-hedging (Stearns, 1976). Under conditions where environmental variability and density independent mortality affect the young more than the adults these two strategies yield contradictory predictions. In a fluctuating environment $r$ - and $\mathrm{K}$-selection predicts $\mathrm{rapid}$ development, early maturation, semelparity, large reproductive effort, more young, and shorter life; bet-hedging predicts just the opposite. Al though contradictary results are predicted by the two 
theories it is often difficult to classify a particular species because of complicating factors (Stearns, 1976).

In a previous study on growth and environmental variation it was found that there existed strong and fairly consistant environmental changes with latitude and that growth was correlated to this 1 atitudinal trend (Appeldoorn, 1980). Growth decreased toward the north. In the following discussion some simplifications are made. It is assumed that a decrease in latitude represents an increase in growth and all results will be discussed in a north-south context. This is done strictly for convience; to simplify the discussion of strategies exhibited by the observed trends in population parameters.

Mya arenaria produces vast numbers of planktotrophic larvae. Estimates of its fecundity range from 120,000/year by Brousseau $(1978 \mathrm{~b})$ to 3 or 4 million/spawn ${ }^{1}$ by Belding (1930) and 1 to 5 million/spawn by Stickney (1964). This high fecundity is consistant with the strategy of larval dispersal (Thorson, 1950). Concommitant with high fecundity is high mortality and as a species M. arenaria exhibits a basic pattern of high juvenile mortality and low adult mortality (Brousseau, 1978a). Tris juvenile mortality is by and large density independent (Ayers, 1956).

Overlying this basic pattern are two observable trends in

1 For a 2.5 inch clam Belding reported a fecundity of 4 million in the text, but 3 million in a summary of Mya's life-history. Earlier publications of this work (Belding, 1907; 1916) gave no figures for absoluted fecundity. It remains unclear which figure is correct al though the latter figure is most often quoted (e.g. Turner, 1948; Ayers, 1956; Dow and Wallace, 1961; Brousseau, 1978b). 
mortality. First, adult mortality increases toward the soutr. This is indicated by reduced longevity in the faster growing populations. Evidence for this trend is also found in the literature, with a reported Iife span for Mya of 5 years in Che sapeake Bay (Pfitzenmeyer, 1972), 12 years in Massachusetts (Belding, 1930), and over 20 years in Nova Scotia (Vandermeulen, 1977). This trend is probably ove to temperature effects. Mya arenaria is a boreal species (Laursen, 1966) and is under temperature stress in the southern part of its range (Pfitzenmeyer, 1972). Second, juvenile mortaltiy becomes more variable toward the south as evidenced by the positive correlation between $\omega$ and VJM. This implies that the environment is more variable toward the south. In Chesapeake Bay Mya can be limited by high temperatures, low salinity, low disolved oxygen (Pfitzenmeyer, 1972) and unsuitable substrate conditions (Pfitzenmeyer and Drobeck, 1963). Bayne (1965) showed with Mytilus edilis than any delay in finding a suitable substrate for settlement may exhaust energy reserves and prevent normal metamorphosis; a problem compounded by rapid metabolism at high temperatures. In addition, with increased submergence, southern populations are exposed to more consistant predation pressure after settlement.

These two opposing mortality trends would make any apriori prediction of a Iife-history strategy for Mya difficult. However, the trends observed in the present study reveal a consistant north-south pattern. (1) Growth rate increases. When the environment becomes more variable with respect to the juveniles the best strategy is to grow quickly and thereby escape the problems faced by small clams. With Mya, increased growth means an increase 
in burial depth and protection from short-term adverse environmental conditions and predation. (2) On the basis of size there is a delay in maturation. Al though not strong, this relationship is supported in the literature. The size of maturation is reported as $25 \mathrm{~mm}$ in Chesapeake Bay (Pfitzenmeyer, 1972), $20 \mathrm{~mm}$ in southern New England (Coe and Turner, 1938), and $15 \mathrm{~mm}$ in Maine (Hanks, 1963). Delayed reproduction allows more energy to be allocated toward early growth and also reduces the demand on resources already strained by high metabolic activity. Al though a cost of reproduction has not been demonstrated for Mya, such a cost as measured by increased stress and mortality has been observed in Mytilus edulis (Bayne et al, 1978). The diverting of productivity toward growth in early life, however, results in an increased reproductive potential in later life due to a general fecundity-si ze relationship (Brousseau, 1978b). (3) Egg density decreases. Assuming equal gonadal volumes this would mean fewer eggs/brood. Since the possibility of a total reproductive failure from a single spawn increases towards the south, it would be advantageous to reduce the output/spawn but have more spawns. Ropes and Stickney (1965) gave evidence for such a trend in spawning. Northern populations spawned only once. Populations in the mid-range can spawn twice if conditions are favorable. The frequency of the second spawn increases towards the south. Two spawns are the rule in Chesapeake Bay (Pfitzenmeyer, 1962; 1965; Shaw, 1962; 1965).

Egg size increases. The production of 1 arger eggs may be interpreted as an attempt to increase survival amoung the larvae. Studies by Vance (1973) and Crisp (1975) indicate that the planktotrophic larval strategy is optimized when the maximum number of eggs are produced 
subject to the constraint that each egg contains the minimum energy reserve necessary for successful larval development to the feeding stage. Consistant with the increase in the VJM, a larger egg size would mean that towards the south Mya needs more energy for successful development. The work of Bame et al. (1975; 1978) on Mytilus edulis and Helm et al. (1973) on Ostrea edulis has demonstrated that egg size has a very significant effect on the development and survival of larvae. Eggs with insufficient energy reserves result in smaller larvae, which remain planktonic longer, and have a decreased capacity for successful metamorhosis and survival .

To summarize: with decreasing latitude there is evidence for an association between an increase in the variability of juvenile mortality, faster growth, delayed maturation, reduced fecundity, more broods/year, and larger eggs. All these traits are consistant with the predictions of the bet-hedging strategy. The only anomolous and confounding trait is the increase in adult mortality already discussed. In variable environments bet-hedging predicts an increase in longevity coupled with a longer reproductive life. This clearly does not occur in Mya. However, the shortened reproductive life observed toward the south is somewhat offset by an increased frequency of spawning and a greater age-specific fecundity due to a larger age-specific size. A reduction in the total mmber of spawning seasons should be associated with a reduction in the juvenile mortality/adul mortaltiy ratio (Stearns, 1976). In this sense the trends may be consistant since there is an increase in adult mortality toward the south while larger eggs may help reduce 
juvenile mortality toward the south.

The above discussion considers the 1 ife-history adaptations of populations to environmental conditions. These are adaptations to long-term variations and are therefore assumed to be genetic in nature. Direct evidence of genetic differences in Mya arenaria is scarce. Morgan et al. (1975) did report genetic differences between clams from Chesapeake Bay and Maine. Clams from Chesapeake Bay where found to have greater polymorphism and heterozygosity.

Effects of Local Environmental Variability

Organisms adapt genetically to long-term environmental variations. Within trat genetic framework there can also be physiological response to short-term variations in the environment. The evidence to date indicates that an increase in stress results in reduced reproduction. In the present study there was a correlation amoung proximal populations between egg density, egg size, and to a lesser degree patrological condtion indicating that when conditions are good more and larger eggs are produced. Brouseau (1978b) found a direct relationship between egg size and fecundity when comparing spring and summer spaws and she showed that total fecundity could vary between both seasons and years. However, no connection was made between reproduction and the conditon of the population. Coe and Turner (1938) reported that the number of young ovocytes developing to mature ova was dependent upon the nutritional condition of the individual. These findings for Mya are consistant with those reported by Bayne $(1972 ; 1976)$ and Bayne et al. (1975; 1978) for Mytilus edulis. They found that in stressed individuals fewer, 
smaller eggs were produced resulting in larvae with reduced viability. It is assumed that under local conditions of stress Mya responds in a manner similar to that observed for Mytilus.

ACKNOWLEDGEMENTS The author wishes to express his gratitude to those people who assisted in clam collection, particularly R.L. Dow, M. Richards, J.M. Hickey, M.L.H. Thomas, and M. Worobec; and to those people who were involved in sample processing, notably R.S. Brown, J. Keller, A. Miller, and S. Polofsky. S.B. Saila, A.N. Sastry, and R.C. Bullock reviewed the manuscript. Financial support for sample collection was provided by a grant from the American Petroleum Institute to Dr. Saila. 
REF ERENCES

Appeldoorn, R.S.: Variation in the growth rate of Mya arenaria and its relationship to the environment as anal yzed through principal components analysis and the $w$ parameter of the von Bertal anffy equation. Ph.D. Thesis. University of Rhode Island 1980

Ayers, J.C.: Population dynamics of the marine clam, Mya arenaria. Limnol. Oceanogr. 1, 26-34 (1956)

Bayne, B.I.: Growth and the delay of metamorphosis of the larvae of Mytilus edulis (L.). Ophelia 2, 1-47 (1965) Bayne, B.L.: Some effects of stress in the adult on the larval development of Mytilus edulis. Nature (London) 237, $459(1972)$

Bayne, B.L.: Aspects of reproduction in bivalve molluscs. In: Estuarine processes, Vol. I. Uses, stresses and ad aptation to the estuary (M. Wiley, ed) pp. 259-277. Columbia, South Carolina: University of South Carolina Press 1976

Bayne, B.L., Gabbott, P.A., Widdows, J.: Some effects of stress in the adult on the eggs and larvae of Mytilus edulis L. J. Mar. Biol. Ass. U.K. 55, 675-689 (1975)

Bayne, B. L., Holl and, D. L., Moore, M.N., Lowe, D.M., Widdows, J.: Further studies on the effects of stress in the adult on the eggs of Mytilus edulis.

J. Mar. Biol. Ass. U.K. 58, 825-841 (1978)

Belding, D. L.: Report on the shellfisheries of Massachusetts. 
Ann. Rept. Div. Fish Game, Mass. 41, 46-53 (1907)

Belding, D.L.: A report on the clam fishery.

Ann. Rept. Div. Fish Game, Mass. 50, 93-234 (1916)

Belding, D.L.: The soft-shelled clam fishery of

Massachusetts. Mar. Fish. Ser. Div. Fish Game Mass. 1, $1-65(1930)$

Brousseau, D. J.: Population dynamics of the soft-shell clam

Mya arenaria. Mar. Biol. (Berlin) 50, 63-71 (1978a)

Brousseau, D. J.: Spawning cycle, fecundity, and recruitment

in a population of soft-shell clam, Mya arenaria, from

Cape Ann, Massachusetts. Fish. Bull. 76, 155-166 (1978b)

Brown, R.S., Wolke, R.E., Saila, S.B., Brown, C.W.:

Prevalence of neoplasia in $10 \mathrm{New}$ England populations of the soft-shell cla (Mya arenaria).

Ann. N. Y. Acad. Sci. 288, 522-534 (1977)

Brown, R.S., Wolke, R.E., Brown, C.W., Saila, S.B.:

Hydrocarbon pollution and the preval ence of neoplasia in New England soft-shell clams (Mya arenaria). In:

Animals as monitors of environmental pollutants (F.M. Peters, ed), pp. 41-51. Washington, D.C.: National Academy of Sciences 1979

Coe, W.R., Turner, H. J.: Development of the gonads and gametes of the soft-shell clam (Mya arenaria).

J. Morphol. 62, 91-111 (1938)

Crisp, D.J.: The role of the pelagic larva. In:

Perspectives in experimental biology, Vol. I (P.S. Davis, 
ed), pp. 145-155. Oxford: Pergamon Press 1975

Fretter, V., Graham, A.: Reproduction. In: Physiology of mollusca, Vol. I (K.M. Wilbur and C.M. Yonge, eds), pp. 127-164. New York: Academic Press, Inc. 1964

Gallucci, V.F., Quinn, T.J.: Reparameterizing, fitting, and testing a simple growth model.

Trans. Am. Fish. Soc. 108, 14-25 (1979)

Hanks, R.W.: The soft-shell clam. U.S. Fish. Wildl. Serv., Circ. 162, 1-16 (1963)

Haukioja, E., Hakala, T.: Life-history evolution in Anodonta piscinalis (Mollusca, Pel ec ypoda). Oecologia 35, 253-266 (1978)

Helm, M.M., Holl and, D.L., Ste phenson, R.R.: The effect of supplementary algal feeding of a hatchery breeding stock of Ostrea edulis (L.) on larval vigor.

J. Mar. Biol. Ass. U.K. 53, 673-684 (1973)

Helwig, J.T., Council, K. A.: SAS user's guide, 1979 edition. Raleigh, North Carolina: SAS Institute Inc. 1979

Holl ander, M., Wol fe, D.A.: Nonparametric statistical methods. New York: John Willey \& Sons 1973 Laursen, D.: The genus Mya in the arctic region. Malacologia 3. $399-418(1966)$

Mackenzie, C.L.: Manag ement for increasing clam abundance. Mar. Fish. Rev. $41(10), 10-22$ (1979)

Morgan, R.P., Block, S.B., Ul anowicz, N.I., Buys, C.: Genetic variation in the soft-shelled clam. Mya arenaria. Estuaries 1, 255-258 (1978) 
Pelseneer, P: La proportion relative des sexes chez les animaux et particulierment chez les mollusques. Mem. Cl. Sci., Acad. R. Belg., Collect. $8^{\circ}$ 8, 1-258 (1926)

Pfitzenmeyer, H.T.: Periods of spawning and setting of the soft-shelled clam, Mya arenaria, at Solomons, Maryl and. Che sapeake Sci. 3, 114-120 (1962)

Pfitzenmeyer, H.T.: Annual cycle of gametogenesis of the soft-shelled clam, Mya arenaria at Solomons, Maryl and. Che sapeake Sci. 6, $52-59$ (1965)

Pfitzenmeyer, H.T.: Tentative outl ine for inventory of Molluses: Mya arenaria (soft shell $\mathrm{clam}$ ). Chesapeake Sci. 13, S182-S 184 (1972)

Pfitzenmeyer, H.T., Drobeck, K.G.: Benthic survey for populations of soft-shelled clams, Mya arenaria, in the lower Potomic River, Maryl and. Chesapeake Sci. 4, 67-74 (1963)

Porter, R.G.: Reproductive cycle of the soft-shell clam, Mya arenaria, at Skagit Bay, Washington. Fish. Bull. 72, 648-656 (1974)

Ricker, W.E.: Linear regression in fishery research. J. Fish. Res. Board Can. 30, 409-434 (1973)

Ricker, W.E.: Computation and interpretation of biological statistics of fish populations. Bull. Fish. Res. Board Can. 191, 1-382 (1975)

Ropes, J.W., Stickney, A.P.: Reproductive cycle of Mya arenaria in New England. Biol. Bull. Woods Hole, 
Mass. 128, 315-327 (1965)

Shaw, W.N.: Seasonal gonadal changes in female soft-shell clams, Mya arenaria in the Tred Avon River, Maryl and. Proc. Natl. Shellfish. Assoc. 53, 121-132 (1962)

Shaw, W.N.: Seasonal gonadal cycles of the male soft-shell clam, Mya arenaria, in Maryl and. U.S. Fish Wildl. Serv. Spec. Sci. Rep. Fish. 508, 1-5 (1965)

Stearns, S.C.: Life history tactics: a review of the ideas. Q. Rev. Biol. 51, 3-47 (1976)

Stickney, A.P.: Sal inity, temperature, and food requirements of soft-shell clam larvae in laboratory culture. Ecology $45,283-291(1964)$

Thompson, R.J.: Fecundity and reproductive effort in the blue mussel (Mytilus edulis), the sea urchin (Strongylongcentrotus diobachiensis), and the snow crab (Chionoecetes opilio) from populations in Nova Scotia and Ne wfo und land. J. Fish. Res. Board Can. 36, 955-964 (1979)

Thorson, G.: Reporductive and larval ecology of marine bottom invertebrates. Biol. Rev. Cambridge Philos. Soc. 25, $1-45(1950)$

Turner, H.J.: Report on investigations of the propagation of the soft-shell clam, Mya arenaria. Rep. Invest. Shellfish. Mass. 1, 3-9 (1948)

Vance, $R_{0} R_{0}:$ On reproductive strategies in marine benthic invertebrates. Am. Nat. 107, 339-352 (1973)

Vandermeul en, J.H.: The Chedabucto Bay spill - Arrow, 1970. 
Oceanus 20(4), 31-39(1977)

Walker, H.A., Lorda, E., Saila, S.B.: A comparison of the incicence of five pathological conditions in soft shell clams Mya arenaria from environments with various pollution histories. Mar. Environ. Res. (in press) 
Appendix A.

Complete References Cited 
American Society for Testing Materials: Grain-size analysis of soils. D422-63. A.S.T.M. Stand ards 11, 205-216 (1963) Anderson, J.W.: Responses to sublethal levels of petroleum hydrocarbons: are they sensnsitive indicators and do they correlate with tissue contamination? In: Fate and Effects of Petroleum Hydrocarbons in Marine Ecosystems and Organisms (D.A. Wolfe, ed.) pp. 95-114. New York: Pergamon Press. 1977

Appeldoorn, R.S.: The response of population growth rate in the soft-shell clam. Mya arenaria, to the onset and abatement of pollution. Ph.D. Thesis. University of Rhode Isl and $1980 \mathrm{a}$

Appeldoorn, R.S.: Variation in the growth rate of Mya arenaria and its relationship to the environment as analyzed through principal components analysis and the $w$ parameter of the von Bertal anffy equation. Ph.D. Thesis. University of Rhode Isl and $1980 \mathrm{~b}$

Ayers, J.C.: Population dynamics of the marine clam, Mya arenaria. Limnol. Oceanogr. 1, 26-34 (1956)

Barr, A.J., J.H. Goodnight, J.P. Sall, and J.T. Helwig: A User's Guide to SAS 76. Sparks Press. Raleigh, North Carolina. 329 pp. (1976)

Bayne, B.L.: Growth and the delay of metamorphosis of the 1 arvae of Mytilus edulis (L.). Ophelia 2, 1-47 (1965) Bayne, B.L.: Some effects of stress in the adult on the larval development of Mytilus edulis. Nature (London) 237. 
$459(1972)$

Bayme, B.L.: Aspects of reproduction in bivalve molluscs.

In: Estuarine processes, Vol. I. Uses, stresses and adaptation to the estuary (M. Wiley, ed) pp. 259-277. Col umbia, South Carolina: University of South Carolina Press 1976

Bayme, B.I., Gabbott, P.A., Widdows, J.: Some effects of stress in the adult on the eggs and larvae of Mytilus edulis L. J. Mar. Biol. Ass. U.K. 55, 675-689 (1975)

Bayne, B.L., Holl and, D. L., Moore, M.N., Lowe, D.M., Widdows, J.: Further studies on the effects of stress in the adult on the eggs of Mytilus edulis. J. Mar. Biol. Ass. U.K. 58, 825-841 (1978)

Belding, D. L.: Report on the shellfisheries of Massachusetts. Ann. Rept. Div. Fish Game, Mass. 41, 46-53 (1907)

Beloing, D. L.: A report on the clam fishery. Ann. Rept. Div. Fish Game, Mass. 50, $93-234$ (1916)

Belding, D.L.: The soft-shelled clam fishery of Massachusett.s. Mar. Fish. Ser. Div. Fish Game Mass. 1, $1-65(1930)$

Beaven, G.F.: Temperature and sal inity of surface water at Solomons, Maryl and. Che sapeake Sci. 1, 2-11 (1960)

Blumer, M., and J. Sass: Oil pollution: persistence of degradation of spilled fuel oil. Science 176, 1120-1122 (1972)

Bl umer, M., G. Souza, and J. Sass: Hydrocarbon pollution of edible shellfish by an oil spill. Mar. Biol. 5, 195-202 
(1970)

Brousseau, D.J.: Population dymics of the soft-shell clam Mya arenaria. Mar. Biol. (Berlin) 50, 63-71 (1978a)

Brousseau, D. J.: Spawning cycle, fecundity, and recruitment in a population of soft-shell clam, Mya arenaria, from Cape Ann, Massachusetts. Fish. Bull. 76, 155-166 (1978b)

Brousseau, D. J.: Analysis of growth rate in Mya arenaria

using the von Bertal anffy equation. Mar. Biol. 51, 221-227 (1979)

Brown, R.S., Wolke, R.E., Saila, S.B., Brown, C.W.:

Preval ence of neoplasia in 10 New England populations of the soft-shell clam (Mya arenaria). Ann. N. Y. Acad. Sci. 288, 522-534 (1977)

Brown, R.S., Wolke, R.E., Brown, C.W., Saila, S.B.: Hydrocarbon pollution and the prevalence of neoplasia in New England soft-shell clams (Mya arenaria). In: Animals as monitors of environmental pollutants (F.M. Peters, ed), pp. 41-51. Washington, D. C.: National Academy of Sciences 1979

Buchanan, J.: Sediments. In: Methods for the Study of Mar ine Benthos, pp 30-51. Ed. by N.A. Holme and A. D. McIntyre, Ox ford: Blackwell Scientific Publications 1971

Cloern, J.E., and F.H. Nichols: A von Bertal anffy growth model with a seasonally varying coefficient. J. Fish. Res. Bd Can. 35, 1479-1882 (1978) Coe, W.R., Turner, H.J.: Development of the gonads and 
gametes of the soft-shell clam (Mya arenaria).

J. Mor phol. 62, 91-111 (1938)

Crisp, D.J.: The role of the pelagic larva. In:

Perspectives in experimental biology, Vol. I (P.S. Davis, ed). pp. 145-155. Oxford: Pergamon Press 1975

Dickie, L. M.: Addendun: mathematical models of growth. In: Methods for Assessment of Fish Production in Fresh Waters, pp 120-123. Ed. by W.E. Ricker, Oxford: Bl ackwell

Scientific Publications 1971

Dow. R.L.: Reduced growth and survivial of clams transplanted to an oil spill site. Mar. Pollut. Bull. 6, $124-125(1975)$

Dow. R.L.: Size-selective mortalities of clams in an oil spill site. Mar. Pollut. Bull. 9, 45-48 (1978)

Dow. R.L., and J.W. Hurst, Jr.: Renewable resource problems of heavy metal mining in coastal Maine. Maine Sea and Shore Fisheries Research Bulletin 35, 1-8 (1972)

Dow, R.L., and J.W. Hurst, Jr.: The ecological, chemical, and histopathological evaluation of an oil spill site. Part I. Ecological studies. Mar. Pollut. Bull. 6, 164-166 (1975)

Dow, R.L., and D.E. Wallace: The soft-shell clam industry of Maine. Circ. Fish Wilfl. Serv., Wash. 110, 1-36 (1961)

Eisler, R.: Toxicity evaluation of a complex metal mixture to the soft-shell clam. Mar. Biol. 43, 265-276 (1977)

Eisler, R., and R.J. Hennekey: Acute toxicities of $\mathrm{Cd}^{2+}$, $\mathrm{Cr}^{+6}, \mathrm{Hg}^{2+}, \mathrm{Ni}^{2+}$, and $\mathrm{Zn}^{2+}$ to estuarine macrofauna. Arch. Environm. Contam. Toxicol. 6, 315-323 
(1977)

Fong, W.C.: Uptake and retention of Kuwait Crude Oil and its effects on oxygen uptake by the soft-shell clam, Mya arenaria. J. Fish. Res. Board Can. 33, 2774-2780 (1976)

Fretter, V., Graham, A.: Reproduction. In: Physiology of mollusca, Vol. I (K.M. Wilbur and C.M. Yonge, eds), pp. 127-164. New York: Academic Press, Inc. 1964

Gallucci, V.F., Quinn, T.J.: Reparameterizing, fitting, and testing a simple growth model. Trans. Am. Fish. Soc. 108, $14-25(1979)$

Gerking, S.D.: Evidence of aging in natural populations of fishes. Gerontologia 1, 287-305 (1957)

Gilbert, M.A.: Growth rates, long evity and maximum size of Macoma balthica (L.). Biol. Bull. mar. bio. lab., Woods Hole 145, 119-126 (1973)

Gilfillan, E.S., S.A. Hanson, D.J. Page, D. Mayo, J. Cooly, J. Chal fant, T. Archambeaul t, A. West, and J.C. Har shbarger: Comprehensive study of petroleum hydrocarbons in the marine environment at Long Cove, Searsport, Maine. Final Report to the Dept. of Environmental Protection, Contract No. 906439. 192 pp. 1977

Gilfillan, E.S., D. Mayo, S. Hanson, D. Donov an and L.C. Jiang: Reduction in carbon flux in Mya arenaria caused by a spill of No. 6 fuel oil. Mar. Biol. 37, $115-123(1976)$

Gilfillan, E.S., and J.H. Vanoermeulen: Alternations in 
growth and physiology of soft-shell clams, Mya arenaria, chronically oiled with Bunker C from Chedabucto Bay, Nova Scotia, 1970-76. J. Fish. Res. Bd Can. 35, 630-636 (1978) Gunter, G.: Temperature. In: Treatise on Marine Ecology and Pal eoecology, Vol. 1, Ecology, Mem. geol. Soc. Am. 67, pp 159-184. Ed. by J.W. Hedgepath, Boulder, Colorado: Geological Society of America 1957

Hampson, G. R., and E.T. Moul: Salt marsh grasses and \#2 fuel oil. Oceanus 20(4), 25-30 (1977)

Hanks, R.W.: The soft-shell clam. U.S. Fish. Wildl. Serv., Circ. 162, 1-16 (1963)

Haukioja, E., Hakala, T.: Life-history evolution in Anodonta piscinalis (Mollusca, Pelecypoda). Oecologia 35, 253-266 (1978)

Helm, M.M., Holl and, D.L., Stephenson, R. R.: The effect of supplementary algal feeding of a hatchery breeding stock of Ostrea edulis (L.) on larval vigor. J. Mar. Biol. Ass. U.K. 53, 673-684 (1973)

Hel wig, J. T., Council, K.A.: SAS user's guide, 1979 edition. Raleigh, North Carolina: SAS Institute Inc. 1979 Holl ander, M., Wolfe, D.A.: Nonparametric statistical methods. New York: John Willey \& Sons 1973

Hyl and, J. L., and E.D. Sehneider: Petrol eum hydrocarbons and their effects in marine organisms, populations, communities, and ecosystems. In: Sources, Effects and Sinks of Hydrocarbons in the Aquatic Environment. Proceedings of a conferance held 9-11 August, 1976. 
pp. 436-506. Washington, D.C.: American Institute for

Biological Sciences. 1976

Jeffries, H.P.: Environmental characteristics of Raritan Bay,

a polluted estuary. Limnol. Oceanogr. 7, 21-31 (1962)

Kellogg, J.L.: Conditions governing existence and growth of

the soft clam. Report of the special commission for the

investigation of the lobster and the soft-shell clam.

Rept. Comm. year ending June 30, 1903.

U.S. Govt. Print. Office 29, 195-224. (1905).

Kennish, M.J., and R.K. Oll son: Effects of thermal discharges

on the microstructural growth of Mercenaria mercenaria.

Environ. Geol . 1, 41-64 (1975)

Knauss, J.A.: Introduction to Physical Oceanography, $338 \mathrm{pp}$.

Highl ands, New Jersey: Prentice-Hall 1978

Krumbein, W.C., and L.L. Sloss: Stratigraphy and

Sedimentation, 660 pp. San Francisco: W.H. Freeman and Company 1963

Laursen, D.: The genus Mya in the arctic region. Malacologia 3. 399-418 (1966)

Lytle, J.S., and T.F. Lytle: Sediment hydrocarbons as

environmental indicators in the northeast Gulf of Mexico.

In: Fate and Effects of Petroleum Hydrocarobns in Marine

Ecosystems and Organisms, pp 404-412. Ed. by D. A. Wolfe,

New York: Pergamon Press 1977

Macdonald, P.D.M., and T.J. Pitcher: Age-groups from

size-frequency data: a versitile and efficient method of

anal yzing distribution mixtures. J. Fish. Res. Bd Can. 36, 
987-1001 (1979)

Mackenzie, C. L.: Management for increasing $\mathrm{clam}$ abundance. Mar. Fish. Rev. $41(10), 10-22$ (1979)

Marine Research: Charleston study annual report. April 1974 - March 1975, 241 pp. Falmouth, Massachusetts: Marine Research Ine. 1975

Mayo, D.W., C.G. Cogger, D. J. Donovan, R.A. Gambardella, L. C. Jiang, and J. Quan: The ecological, chemical, and histopathological evaluation of an oil spill site. Part II. Chemical studies. Mar. Pollut. Bull. 6, 166-171 (1975)

Mead, A.D., and E.W. Barnes: Observations on the soft-shell clam (fiftr paper). R.I. Comm. Inland Fish., 34th. Annu. Rep., pp. 29-68 (1904)

Morgan, R.P., Block, S.B., Ul anowicz, N.I., Buys, C.: Genetic variation in the soft-shelled clam. Mya arenaria.

Estuaries 1, 255-258 (1978)

Morrison, D.F.: Multivariate Statistical Methods, $415 \mathrm{pp}$. New York: McGraw-Hill 1976

Munch-Petersen, S.: An investigation of a population of the soft clam (Mya arenaria L.) in a Danish estuary. Meddr Kommn Danm. Fisk.-cg Havunders. 7, 47-73 (1973)

National Ocean Survey: Tide Tables 1979: East Coast of North and South America, including Greenland, 293 pp. Rockville, Maryl and: National Oceanic and Atmospheric Administration, National Ocean Survey 1978

Newcombe, C.L.: A comparitive study of the abundance and the 
rate of growth of Mya arenaria L. in the Gulf of St. Lawrence and Bay of Fundy regions. Ecology 17, 418-428 (1936)

Newcombe. C.L., and H. Kessler: Variations in growth indicies of Mya arenaria L. on the Atlantic coast of North America. Ecology 17, 321-352 (1936)

Pelseneer, P: La proportion relative des sexes chez les animaux et particulierment chez les mollusques.

Mem. Cl. Sci., Acad. R. Belg., Collect. $8^{\circ} 8,1-258$ (1926)

Pfitzenmeyer, H.T.: Periods of spawning and setting of the soft-shelled clam, Mya arenaria, at Solomons, Maryl and. Che sapeake Sci. 3, 114-120 (1962)

Pfitzenmeyer, H.T.: Annual cycle of gametogenesis of the soft-shelled clam, Mya arenaria at Solomons, Maryl and. Che sa peake Sci. 6, 52-59 (1965)

Pfitzenmeyer, H. T.: Tentative outline for inventory of Molluscs: Mya arenaria (soft shell $\mathrm{clam}$ ). Chesapeake Soi. 13, S182-S $184(1972)$

Pfitzenmeyer, H.T., Drobeck, K. G.: Benthic survey for populations of soft-shelled clams, Mya arenaria, in the lower Potomic River, Maryland. Chesapeake Soi. 4, 67-74 (1963)

Porter, R.G.: Reproductive cycle of the soft-shell clam. Mya arenaria, at Skagit Bay, Washington. Fish. Bull. 72, 648-656 (1974)

Ricker, W.E.: Linear regression in fishery research. 
J. Fish. Res. Board Can. 30, 409-434 (1973)

Ricker, W.E.: Computation and interpretation of biological statistics of fish populations. Bull. Fish. Res. Board Can. 191, 1-382 (1975)

Roff, D.A.: A motion for the retirement of the von Bertal anffy function. Can. J. Fish. Aquat. Sci. 37, $127-129(1980)$

Ropes, J.W., Stickney, A.P.: Reproductive cycle of Mya arenaria in New England. Biol. Bull. Woods Hole, Mass. 128, 315-327 (1965)

Rosenberg, R.: Benthic faunal dymamics during succession following pollution abatement in a Sweedish estuary. Oikos 27, $414-427(1976)$

Sameoto, D.D.: Yearly respiration rate and estimated energy budget for Sagitta elegans. J. Fish. Res. Bd Can. 29, 987-996 (1972)

Sanders, H.L.: Benthic studies of Buzzard's Bay. I. Animal-sediment relationships. Limnol. Oceanog $r .3$, $245-258(1958)$

Sanders, H.L.: The West Falmouth oil spill - Florida, 1969. Oceanus $20(4), 15-24(1977)$

Sanders, H.L. :Florida oil spill impact on the Buzzards Bay benthic fauna: West Falmouth. J. Fish. Res. Board Can. 35, $717-730(1978)$

Shaw, W.N.: Seasonal gonadal changes in female soft-shell clams, Mya arenaria in the Tred Avon River, Maryland. Proc. Natl. Shellfish. Assoc. 53, 121-132 (1962) 
Shaw. W.N.: Seasonal gonadal cycles of the male soft-shell clam, Mya arenaria, in Maryl and. U.S. Fish Wildl. Serv. Spec. Sci. Rep. Fish. 508, 1-5 (1965)

Shorey, W.K.: Macrobenthic ecology of a sawdust-bearing substrate in the Penobscot River estuarty (Maine). J. Fish. Res. Bd Can. 30, 493-497 (1973)

Shuster, C.N.: On the formation of midseason checks in the shell of Mya. Anat. Rec. 111, 543 (1951)

Stearns, S.C.: Life history tactics: a review of the ideas. Q. Rev. Biol. 51, 3-47(1976)

Stickney, A.P.: Sal inity, temperature, and food requirements of soft-shell clam larvae in laboratory culture. Ecology $45,283-291(1964)$

Swan, E.F.: The growth of the clam Mya arenaria as affected by the substratum. Ecology $33,530-534$.

Tesch, F.W.: Age and growth. In: Methods for Assessment of Fish Production in Fresh Waters, pp 98-120. Ed. by W. E. Ricker, Ox ford: Blackwell Scientific Publications 1971

Thomas, M.L.H.: Effects of Bunker $\mathrm{C}$ oil on intertidal and lagoonal biota in Chedabuc to Bay, Nova Scotia. J. Fish. Res. Board Can.30, 83-90 (1973)

Thomas, M.L.H.: Comparison of oiled and unoiled intertidal communities in Chedabucto Bay, Nova Scotia. J. Fish. Res. Bd Can. 35, 707-716 (1978)

Thompson, R.J.: Fecundity and reproductive effort in the blue mussel (Mytilus edulis), the sea urchin 
(Strongylongcentrotus diobachiensis), and the snow crab

(Chionoecetes opilio) from populations in Nova Scotia and

Newfoundland. J. Fish. Res. Board Can. 36, 955-964 (1979)

Thorson, G.: Reporductive and larval ecology of marine bottom invertebrates. Biol. Rev. Cambridge Philos. Soc. 25, 1-45 (1950)

Turner, H.J.: Report on investigations of the propagation of the soft-shell clam. Mya arenaria.

Rep. Invest. Shellfist. Mass. 1, 3-9 (1948)

Vance, R.R.: On reproductive strategies in marine benthic invertebrates. Am. Nat. 107, 339-352 (1973)

Vanderhorst, J.R., J.W. Anderson, P. Wilkinson, and D. L. Woodruff: Estimation of effects from oil on intertidal populations: experimental perturbations versus natural variation. In: Procedings of the Conferance on Asse sment of Ecological Impacts of Oil Spills, 14-17 June 1978. pp. 807-820. Washington, D. C.: American Institute for Biological Sciences. 1978

Vandermeul en, J.H.: The Chedabuc to Bay spill - Arrow, 1970. Oceanus $20(4), 31-39(1977)$

Vandermeulen, J.H., and W.R. Penrose: Absence of aryl hydrocarbon hydroxylase ( $\mathrm{AHH}$ ) activity in three marine bivalves. J. Fish. Res. Board Can. 35, 643-647 (1978) Walker, H.A., Lorda, E., Saila, S. B.: A comparison of the incidence of five pathological conditions in soft shell clams Mya arenaria from environments with various pollution histories. Mar. Environ. Res. (in press) 
Wilton, M.H., and H.I. Wilton: Conditions affecting the growth of the soft shell clam, Mya arenaria L.

Contr. Can. Biol. Fish. 4, 81-93 (1929) 